Portland State University

PDXScholar

Environmental Science and Management

Professional Master's Project Reports

2016

\title{
Management Plan for Western Painted Turtle (Chrysemys picta belli) at Fairview Creek Headwaters
}

Ashley Smithers

Portland State University

Follow this and additional works at: https://pdxscholar.library.pdx.edu/mem_gradprojects

Part of the Environmental Indicators and Impact Assessment Commons, and the Environmental Monitoring Commons

Let us know how access to this document benefits you.

\section{Recommended Citation}

Smithers, Ashley, "Management Plan for Western Painted Turtle (Chrysemys picta belli) at Fairview Creek Headwaters" (2016). Environmental Science and Management Professional Master's Project Reports. 50. https://pdxscholar.library.pdx.edu/mem_gradprojects/50 https://doi.org/10.15760/mem.52

This Project is brought to you for free and open access. It has been accepted for inclusion in Environmental Science and Management Professional Master's Project Reports by an authorized administrator of PDXScholar. Please contact us if we can make this document more accessible: pdxscholar@pdx.edu. 
Management Plan for Western Painted Turtle (Chrysemys picta belli) At Fairview Creek Headwaters

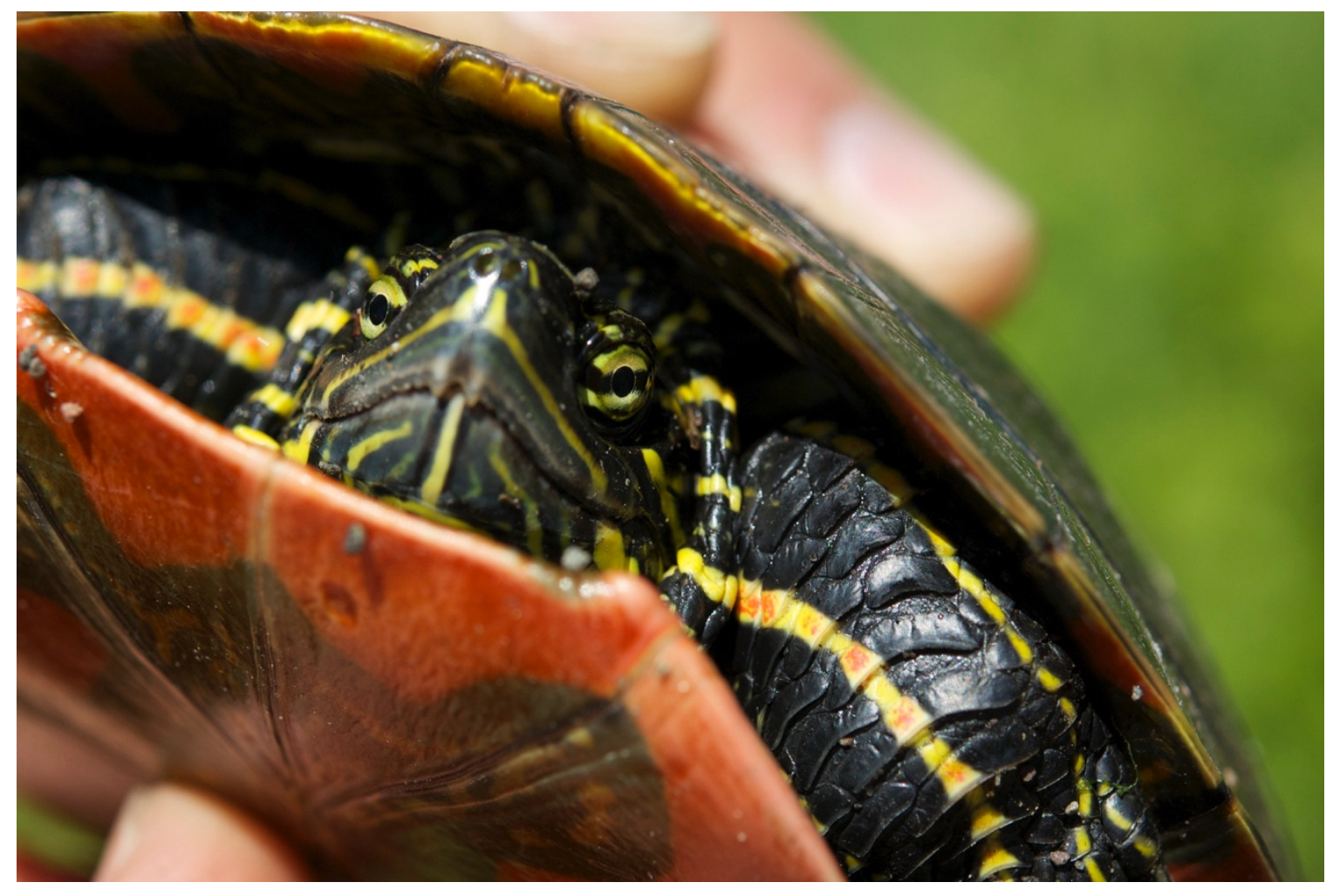

Submitted by Ashley Smithers

Submitted to the City of Gresham Oregon

and

Portland State University 
Abstract

Western painted turtles (Chrysemys picta belli) are found occupying Fairview Creek Headwaters (FCH) in Gresham, Oregon. This urban stream contains a large wetland with an adjacent butte, all managed by the City of Gresham. This management plan addresses the preferred habitat and population of turtles at the site. A habitat delineation of the site revealed specific locations where habitat improvements could take place as well as areas of already beneficial habitat. Two site plans were prepared showing areas of the site that could be enhanced with nesting habitat as well as additional aquatic habitat and basking habitat. A habitat study was conducted comparing the terrestrial and aquatic habitat in the northern part of the site and the southern portion of the site. The northern portion of the site, where the most turtles are seen, was found to have more bare ground, with a rush species and emergent vegetation as indicator species. The southern portion of the wetland was dominated by reed canary grass and birdsfoot trefoil. This area had high plant density with very little bare ground. The aquatic habitat in the southern portion of the wetland had less emergent vegetation and more floating vegetation.

Two management plans were created for Fairview Creek Headwaters northern section of the site. The first plan is a low impact plan, focusing on nesting habitat creation along the west edge of the north wetland. Amending the soil as well as maintaining low plant density and adequate bare ground should be the focus of habitat restoration with this plan. Plan 2 is a more comprehensive plan which includes improving aquatic habitat and basking habitat. It is recommended that additional wetland be created in the north end of FCH at the Gantenbein Dairy. There should be a variety of habitat to support all age classes of turtles. Reed canary grass and other non-native species should be managed throughout the site.

Seven years of mark-recapture data collected on the turtle was used to summarize findings on the turtle population. Two methods were used to estimate the population size, Lincoln Petersen and Schnabel methods. The Lincoln Peterson method estimated 119 individuals while the Schnabel estimate was 94 individuals. The sex ratio of the population was close to 1:1 with most years having slightly more females caught. A theoretical model of the population growth rate was built to detect which age class (hatchling, juvenile, small adult or large adult) is most important to the conservation of the species. Small and large adults were found to have the largest value for contributions to future generations. Furthermore, maintaining a high survivorship rate for these two age classes is essential for maintaining a positive population growth rate. Thus management should focus on habitat that benefits adult populations.

This study and its resultant management plan focuses on managing the population of painted turtles. It should be considered with other recommendations when making a comprehensive site plan. 


\section{Table of Contents}

Chapter 1: Introduction, Site History, Literature Review ..................................... 5

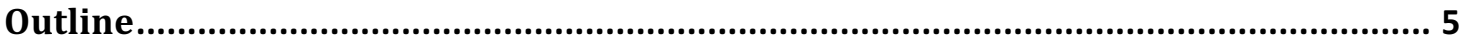

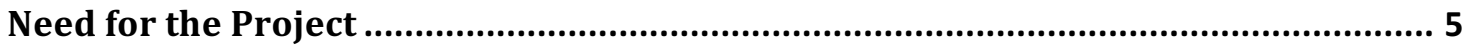

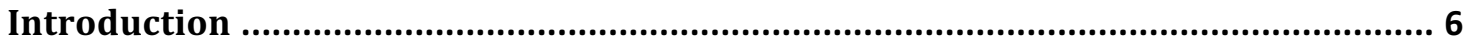

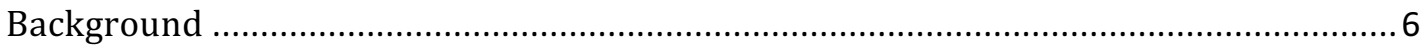

History of the Willamette Valley: Urbanization in the Valley ………………………….... 10

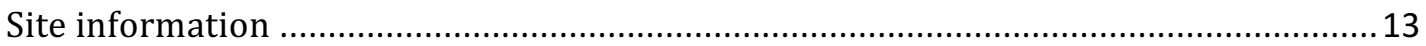

Species: Western Painted Turtle (Chrysemys picta bellii) ............................................. 19

Chapter 2: Habitat ................................................................................................... 26

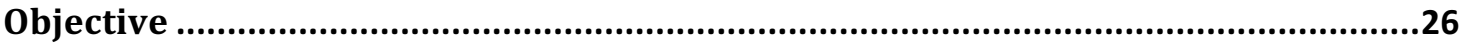

Literature Review: Habitat needs............................................................................26

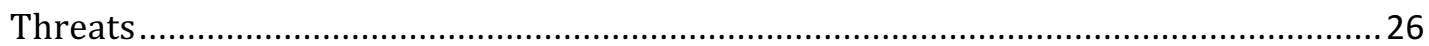

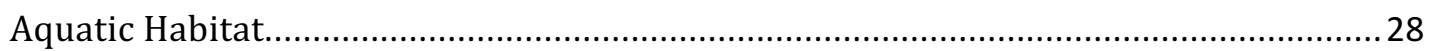

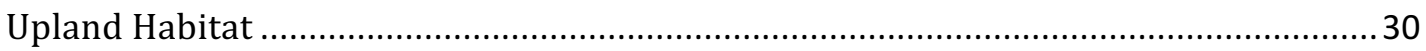

Current Status of Basking and Nesting habitat at FCH ................................................31

Current status of basking habitat at FCH ……………………………………….......

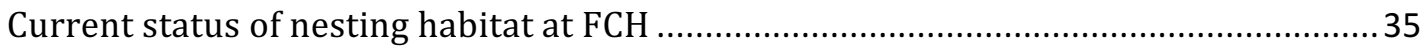

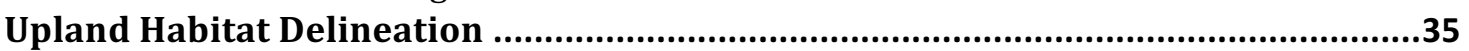

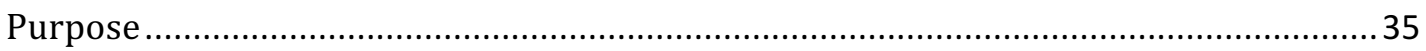

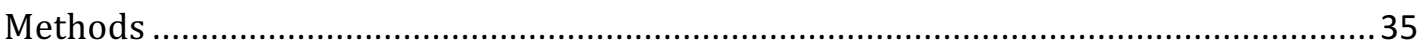

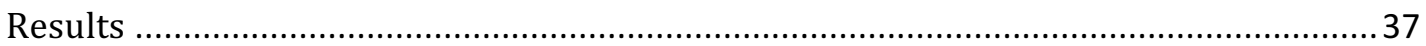

Habitat Study: Habitat differences between the North and South .............................39

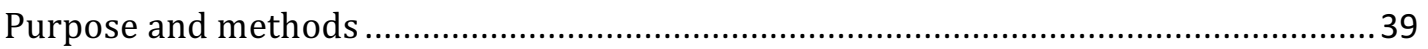

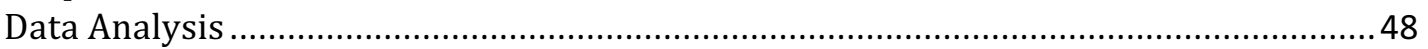

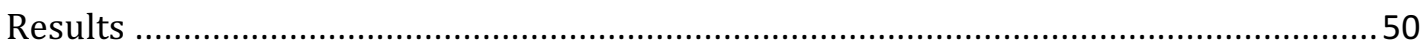

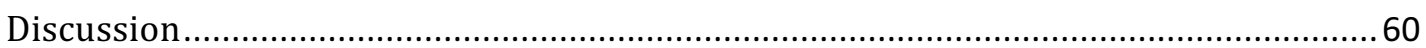

Chapter 3: Population ...........................................................................................6 62

Objective and Purpose ............................................................................................62

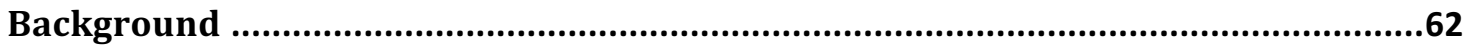

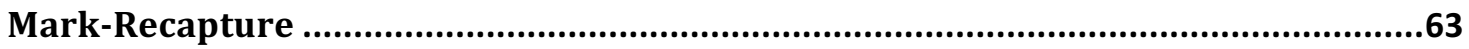

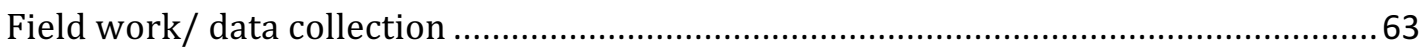

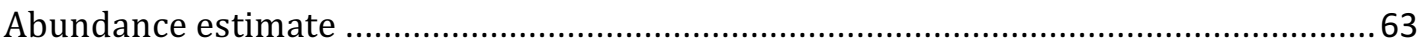

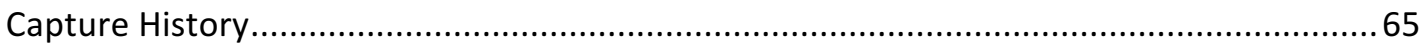

Population Growth Rate Model......................................................................................69

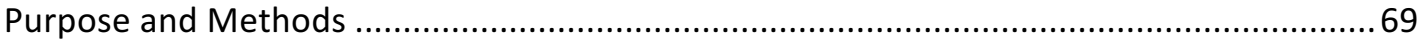

Matrix model and Parameters................................................................................. 71

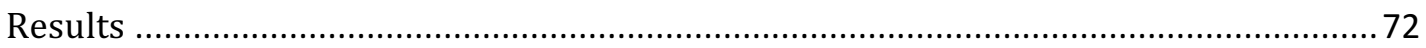

Discussion of Model ..............................................................................................

Chapter 4: Management Plan ............................................................................. 77

Objective ..................................................................................................................

Habitat Recommendations.......................................................................................77

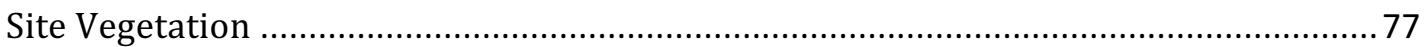

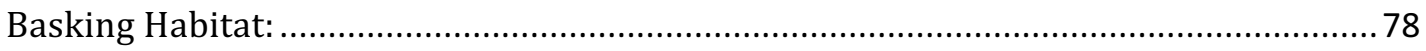

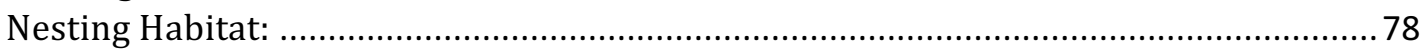




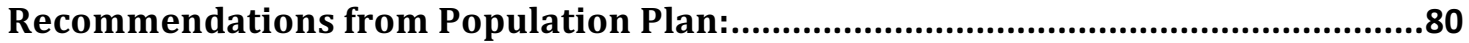

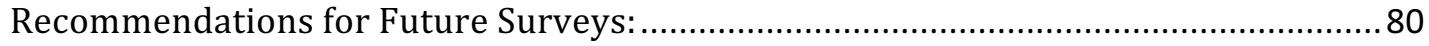

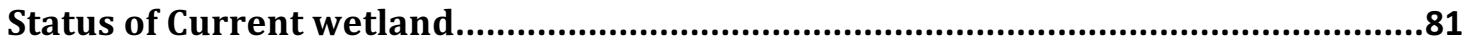

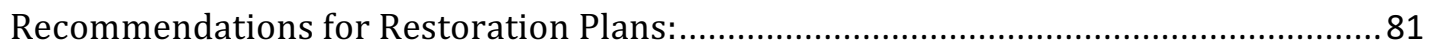

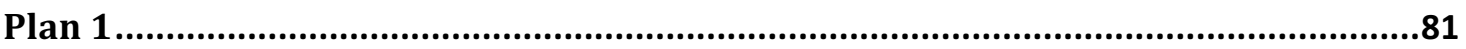

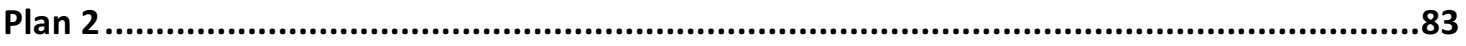

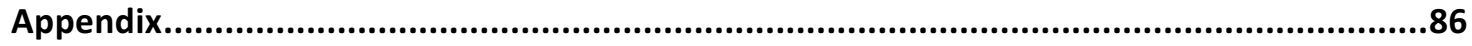

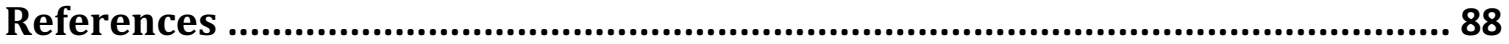




\title{
Chapter 1: Introduction, Site History, Literature Review
}

\author{
Outline
}

This management plan was created for the City of Gresham to provide recommendations for management of the population of western painted turtles (Chrysemys picta belli) at the Fairview Creek Headwaters. The city has been tracking the population since 2007 with the goal of enhancing their habitat and ensuring the long-term protection of the species. This project meets the City of Gresham's goals to enhance wildlife habitat, comply with state and federal regulations for water quality and wildlife protection, and maintain a healthy and diverse native wetland community.

This management plan is prepared for the City of Gresham Department of Environmental Services, and is the focus of Ashley Smithers' Masters of Environmental Management degree.

Need for the Project

The City of Gresham recognizes that a population of western painted turtles inhabits the wetland at Fairview Creek Headwaters. Although city staff has been tracking the population through mark-recapture surveys almost every spring and fall since 2007, no one has analyzed these data or to connected these population studies to the overall conservation goals of the city. Furthermore, understanding the habitat needs of the turtles and how changes in the habitat can help maintain a stable population are needs yet to be studied. My research presents the unique opportunity to study urbanization effects on western painted turtles, which is an area of research that has received little attention previously. Additionally, this population and site is important as it is recognized as one of the largest populations on the Northeast end of the Willamette Valley.

The City along with Metro and East Multnomah Soil and Water Conservation District purchased the Gantenbein Dairy, in the fall of 2014. The addition of this property (Gatenbein Dairy) adjacent to the already City-owned headwaters presents the need for a management plan. Furthermore, a population assessment is important for allowing proper site management and the prescription of appropriate restoration activities.

The Management Plan is comprised of three parts:

Chapter 2: Habitat assessment of the headwaters property

Chapter 3: Assessment of the turtle population

Chapter 4: Management Plan and recommendations based on population evaluation and habitat assessment

\section{Chapter 2: Habitat}


The second chapter of this plan is composed of a literature review, results of a habitat delineation, and a habitat study. The literature review focuses on terrestrial and aquatic habitat necessary for turtle persistence, focusing specifically on the urban environment. The use of the habitat for basking, nesting, and overwintering by turtles was the focus of each of the habitat studies. A habitat delineation of the site was completed to identify areas of concern and areas of suitable habitat on the site. An occupancy study compared areas of the site where turtles have been observed basking and nesting to an area of the site where there has been no observed occupancy. Results from the literature review, habitat delineation, and the habitat occupancy study were used for the site management recommendations outlined in Chapter 4.

\section{Chapter 3: Population}

Data collected from 2007 to 2014 were used to analyze Fairview Creek Headwaters' population of western painted turtles. The capture history focused on: the number of captures by year, sex ratios, seasonality of captures, and age structure. An abundance model was built using the spring 2014 capture data. A theoretical model was built to predict how changes in survival rates of various stage classes would impact the growth rate of the population. This model then contributed to understanding how various urban pressures, such as roads, might impact the stability of the population. Findings from this section help in understanding the issues that face this population and where the population management actions and habitat modifications should focus.

\section{Chapter 4: Management Plan}

The management plan combines the results of the habitat section (Chapter 2) and the population assessment (Chapter 3 ) to develop actionable recommendations for conserving this turtle population and its habitat. General recommendations are first made for the entire site, providing recommendations for maintaining the site into the future. I then propose two different restoration plans are proposed as recommendations for restoring the newly acquired Gantenbein Dairy property specifically with turtle habitat enhancements as a priority (Chapter 4: Plan 1 and 2).

\section{Introduction}

Background Effects of Urbanization

Humans are causing one of the greatest extinctions events in history by altering ecosystems, especially in urban areas where some of the largest habitat and biodiversity loss occurs (Shochat et al. 2010; Marzluff 2001). The effects humans have on urban ecosystems is complex with a long list of impacts. We fragment the landscape through increased built environments, including roads. We alter hydrology through the draining of wetlands and creating water diversions, and by 
increasing impervious surface. Finally, we introduce non-native and invasive plant and animal species, which alter the habitat as well as compete with native species. All these alterations, that is, fragmentation, impervious areas, changes in plant and wildlife communities, influence wetlands and fauna that rely on them. Turtles, in particular, are responding to changes in urban areas. Worldwide turtle populations are decreasing, and we are finding urbanization to be a key component of that decrease (Spinks et al. 2003; Baldwin et al. 2004). This project seeks to address how each of these components can be managed at Fairview Creek Headwaters to benefit the population of western painted turtles.

\section{Fragmentation}

The urban environment is often characterized by a highly degraded and fragmented landscape. This fragmentation can impact the quality of the remaining ecosystems found in the urban setting. One of the most apparent impacts is the size of habitat areas, which are generally small and disconnected in urban ecosystems. Wetlands are often lost with increased fragmentation (Bernert et al. 1999). What wetlands remain are often altered by changes in hydrology, increased pollution, and increased sediments (Johnson et al. 2002).

Local biodiversity is lost in the remaining fragmented habitat (Gibbs 2000). Areas of fragmentation in urban areas are homogenous, that is, similar species are found in each area. Many native species are declining or are non-existent in urban areas due to fragmentation and homogeneity of habitat (McKinney 2006). Fragmentation leads to ecosystems with remnant isolated populations that may have lower genetic diversity (Rubin et al. 2001), and experience declining populations with limited dispersal and colonization rates (Galat et al. 1998).

The built environment, including roads, is the main contributor to fragmentation in urban areas (Shepard et al. 2008). Roads bisect the landscape making it difficult for animals to move from one habitat to another and road crossings can result in wildlife fatalities (Proulx et al. 2014; Shepard et al. 2008). The small habitat areas surrounded by roads can act as ecological traps (areas organisms settle which are poor quality habitat), for many species (Aresco 2005). Turtles are attracted to the nesting habitat created along roads, thus acting as ecological traps. Furthermore, species are not able to move from one fragmented area to another, often times being stuck in one "island." In addition, roads also act as pathways for invasive plant and animal species (Wace 1977). These invasions can exacerbate losses of biodiversity of native species and declining population sizes.

\section{Impervious area}

One of the main characteristics of urban area is the increased amount of built environment or impervious surfaces found on the landscape. Increased impervious surfaces impact: hydrology, water quality, the amount of stream meandering, and habitat fragmentation (Dunne and Leopold 1978). Alterations of urban landscapes, such as additions of storm water retention ponds, water treatment facilities, and 
other reductions in pervious area have forced wildlife to adapt and utilize these non-traditional areas or face extirpation (Ehrenfeld 2000; Kentula et al. 2004). The number of people moving into urban areas is increasing, and with that, more built environment is created (United Nations 2014).

\section{Flora and Fauna Communities}

The urban landscapes are becoming homogenized; plant and wildlife species are similar from one urban center to another leading to the decline of local native flora and fauna (McKinney 2006). Furthermore, non-native species are increasing in urban ecosystems. The spatial patterning of the landscape along with the restricted size of vegetation patches in the urban context has some of the greatest impacts on fauna assemblage (Jones and Wieneke 2000; Tait et al. 2005). If these patches are far from each other, movement between them will be difficult, especially with a species like turtles. Furthermore, if these patches are small, or have similar habitat in each, this can result in few rare native species and instead similar species from patch to patch. All these anthropogenic threats to wildlife will continue to rise with the projected increase of human populations into urban areas (Vitousek et al. 1997). Urban conservation should focus on promoting preservation and restoration of local indigenous species (McKinney 2006).

Changes in hydrology, due to increased impervious surfaces and other anthropogenic effects, alter the plant communities in urban areas (Bernert et al. 1999). Wetlands and streams are affected by reductions in the amount of recharge to the water table caused by increased built environment (Klein 1979). The lack of groundwater recharge in turn reduces water in wetlands and changes the wetland hydrology. Reduced water alters the plant communities, which leads to changes in the functional role of a habitat area and the wildlife that uses it. Establishment and recruitment of plant species is further limited by habitat isolation (lack of habitat connectivity) created by fragmentation. Gibbs (2000) found when wetland were spread further apart, especially small bodied wetlands that there was poor dispersal of some organisms such as amphibians, turtles and small mammals. Plants in these areas are dependent on animals for transport from one fragment to another, especially aquatic plant species (Gibbs 2000). Furthermore, urban areas are faced with continual input of non-native and often invasive plant species.

The impacts on wildlife communities are similar to those impacts to plant communities: declining biodiversity, increasing homogeneity across fragmented habitats in the urban core, and increasing non-native and invasive species. Wildlife species in urban area often are forced to adapt to this changing environment or risk local extinction. Wildlife from one city to another is typically the same, with declining native fauna (McKinney 2006) and loss of rare species being common in urban areas. Anthropogenic stresses such as changes of hydrology, inputs of heavy metals, and increased non-native vegetation, leads to changes in aquatic wildlife such as insects, amphibians, and fish. 


\section{Effects of Urbanization on Turtles}

Anthropogenic impacts in urban centers can be especially harmful to native freshwater turtles that are persisting in these environments. Globally, reptiles are declining with $75 \%$ of the turtle species listed as threatened, critically endangered or endangered (IUCN 2011; Gibbons et al. 2000). The longevity of turtle species may delay the appearance of negative impacts on turtle populations due to anthropogenic pressures and habitat alterations such as wetland fragmentation (Rizkalla and Swihart 2006), water quality alterations, vegetation changes, and road density (Congdon et al. 1993; Bodie et al. 2000; DonnerWright et al. 1999; Findlay and Houlahan 1997; Russell et al. 2002).

The draining of wetlands and diverting of local streams is common in urban areas and adds to habitat loss for turtles. Streams are often channelized, subsequently increasing water temperatures and altering invertebrate communities (Nedeau et al. 2003; Violin et al. 2011) which are all things that can impact turtles positively or negatively (see Chapter 2). These alterations may impact turtles through changes in substrate, geomorphology (Montgomery 1999), and hydrology (Leopold 1968). Furthermore, there is an increase in pollutants entering the water in the urban environment including heavy metals, pesticides, oils and detergents (Klein 1979). Additionally, dissolved oxygen was found to impact the overwintering time of turtles in wetlands, and as a result, turtles spend less time in anoxic environments (Crawford 1991; Rollinson et al. 2008).

Freshwater turtles will overwinter in either the substrate of the wetland or in litter found in the uplands. Therefore, adequate wetland habitat regarding water quality (dissolved oxygen (DO), pH, temperature, and pollutants) is especially important in urban areas where the amount of adjacent upland overwintering habitat might be limited. Temperature fluctuations in ponds would also impact the overwintering habits in turtles; when DO is normal turtles pick environments with lower temperatures (Rollinson et al. 2008).

Water quality is known to affect the density and diversity of invertebrates (Nedeau et al. 2003), which are an important food source for turtles (Gibbons 1967). In addition to habitat loss being a major threat to wildlife in urban areas, reptiles are also facing the threat of habitat degradation, introduced species, environmental pollution, disease, human recreation, and climate change (Gibbons et al. 2000). Turtle populations found within cities are not exempt from these pressures (Spinks et al. 2003; Baldwin et al. 2004). Understanding the issues that turtles face in urban environments is essential for starting to understand where management should begin to focus. 
History of the Willamette Valley: Urbanization in the Valley

The Willamette Valley in Oregon, comprising of 9,100 km², was settled by Europeans in the 1800s (Taft and Haig 2003; Benner and Sedell 1997, Hulse et al. 1998). The Willamette Valley is bordered by the Columbia River to the north, and expands to just south of Eugene (Figure 1.1). The valley is bordered by the Cascade Range to the east and the Coast Range to the West. It has a cool Mediterranean climate with an average rainfall of 100-125 cm (Jackson and Kimberling 1993).

Since settlement, the Valley has been dominated by farming, industry, and urbanization (Hulse et al. 1998; Oetter et al. 2000). Titus et al. (1996) found that 456,119 hectares of wetland and riparian area in the Willamette Valley have been lost since European settlement (1840). Most of the wetland loss has been due to agriculture (70\%) and urbanization (6\%) (Bernert et al. 1999). Many species of wildlife depend on these disappearing habitats. As urbanization of the Willamette Valley continues to increase, a focus on urban wildlife, including turtles, should be emphasized. In fact, many of the populations of turtles found in the Willamette Valley are found in high-density urban areas (Gervais et al. 2009).

Gresham, located just east of Portland, Oregon, in the northern end of the Willamette Valley (Figure 1.1) is in the largest urban area (Portland Metro Area) of the Valley and in Oregon. Gresham is the fourth largest city in Oregon with a population of 109,000 (2012 census). The $60.9 \mathrm{~km}^{2}$ city features many parks, natural areas and creeks, but it is still highly urbanized, with 41 percent of the city being impervious or "built" surface (Figure 1.2). 


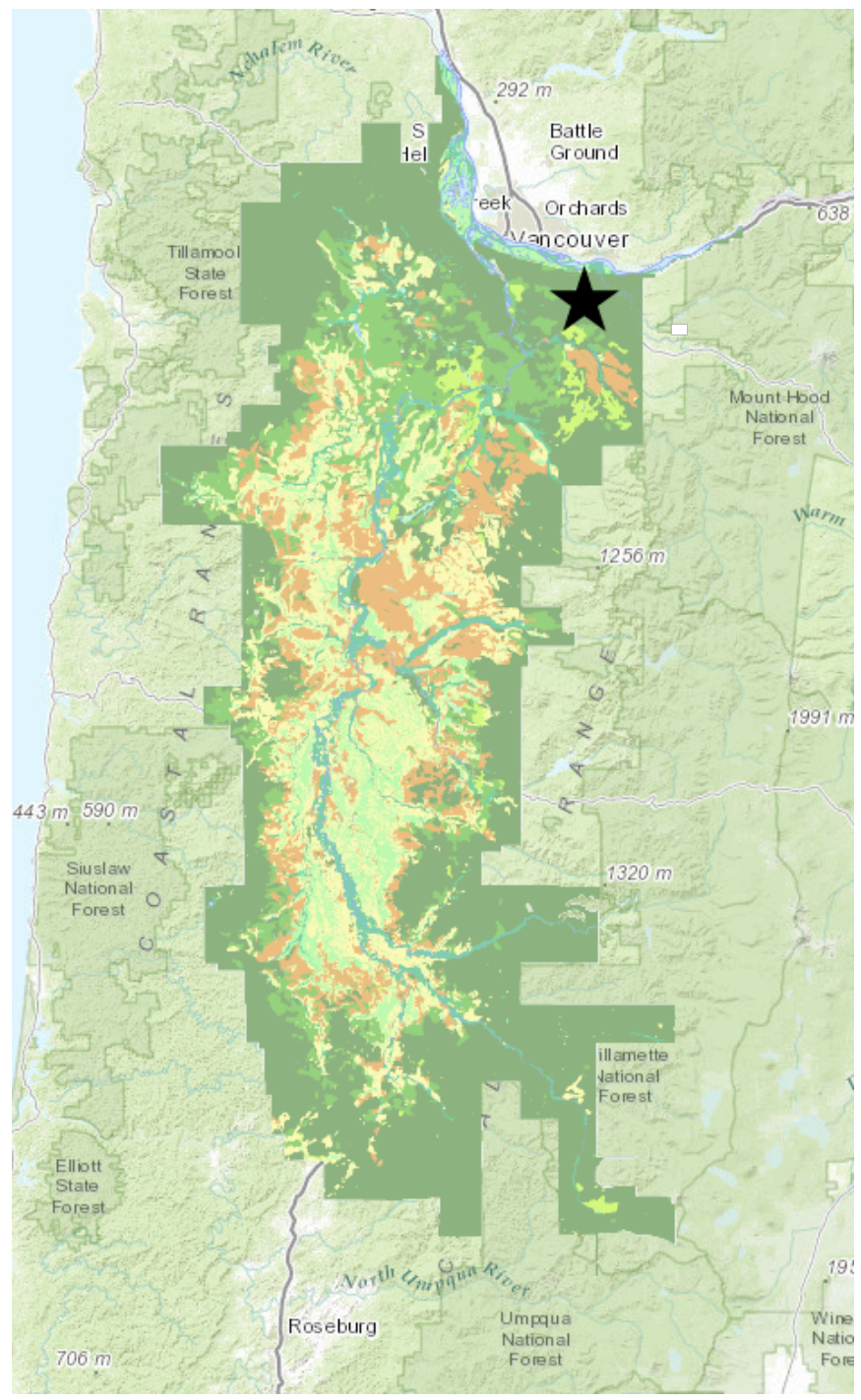

Figure 1.1. Willamette Valley in Oregon. The location of the City of Gresham in the Willamette Valley is indicated by the black star.

Three creeks run through Gresham: Johnson Creek, Kelly Creek, and Fairview Creek. The study site is located along Fairview Creek, a five-mile urban creek which runs through Gresham and Fairview, Oregon. The creek starts at its spring-fed headwaters, in the center of Gresham, and runs north through the city of Fairview and ends in the Columbia Slough at Fairview Lake. The creek is highly urbanized, surrounded by houses and industrial areas for most of its length. A GIS analysis of a $500 \mathrm{~m}$ buffer around the entire creek showed that 40 percent of the land was impervious (Figure 1.2). 


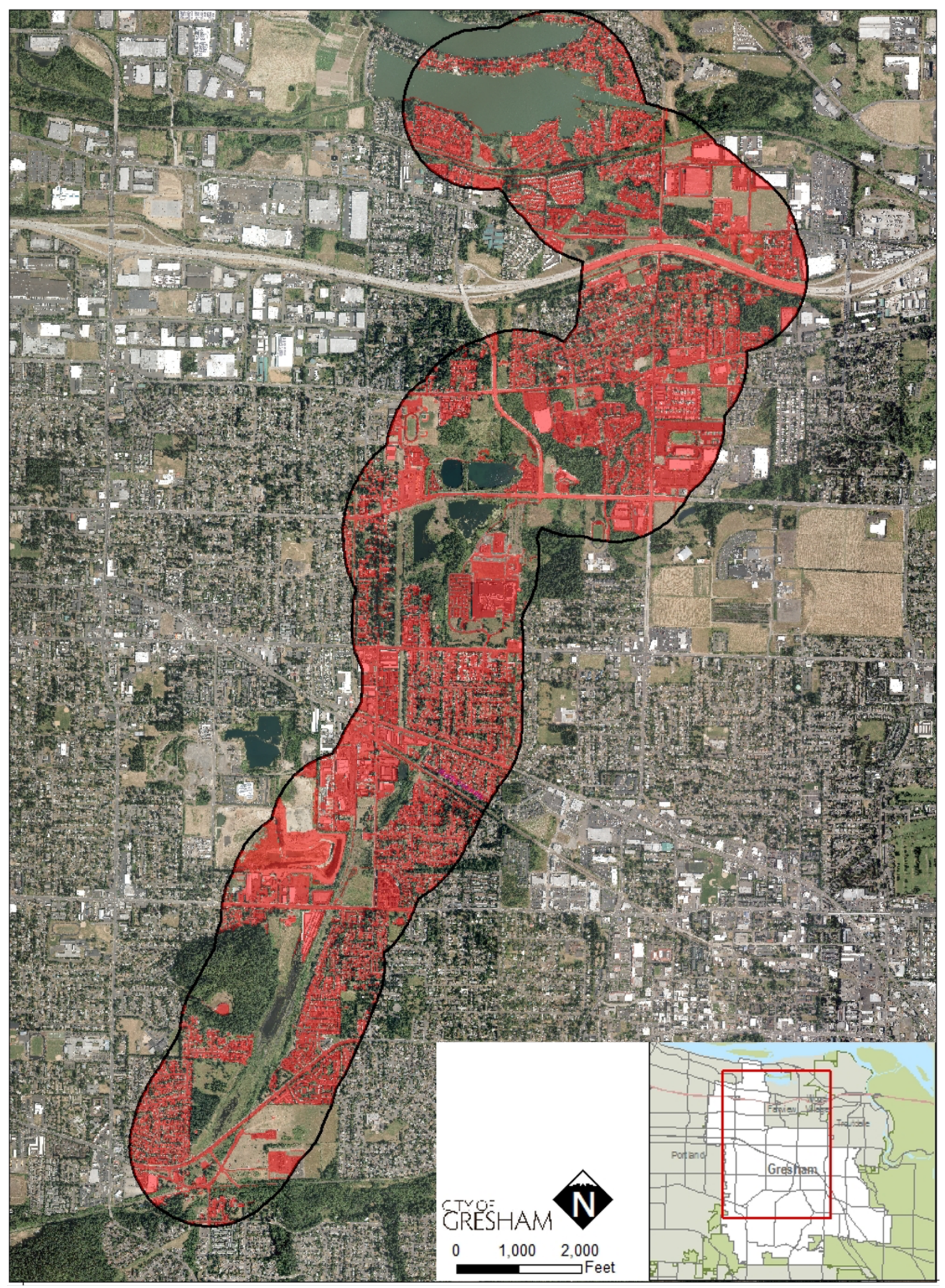

Figure 1.2. Forty percent of the area within a 500-meter buffer of Fairview Creek is impervious (or built) environment. The red indicates built space. 
Site information

\section{Location}

Grant Butte and Fairview Creek make up the 156-acre site called Fairview Creek Headwaters (FCH). Located in Gresham between Southeast $182^{\text {nd }}$ Avenue and Northwest Birdsdale Avenue, the east and west ends of the site are bordered by subdivisions, and the north and south ends are bordered by two busy two-lane streets: Southeast Powell Blvd and Southeast Division (Figure 1.3). Grant Butte is about an 80-acre (measuring all property types), 602 feet high butte in the northwest corner of the property.

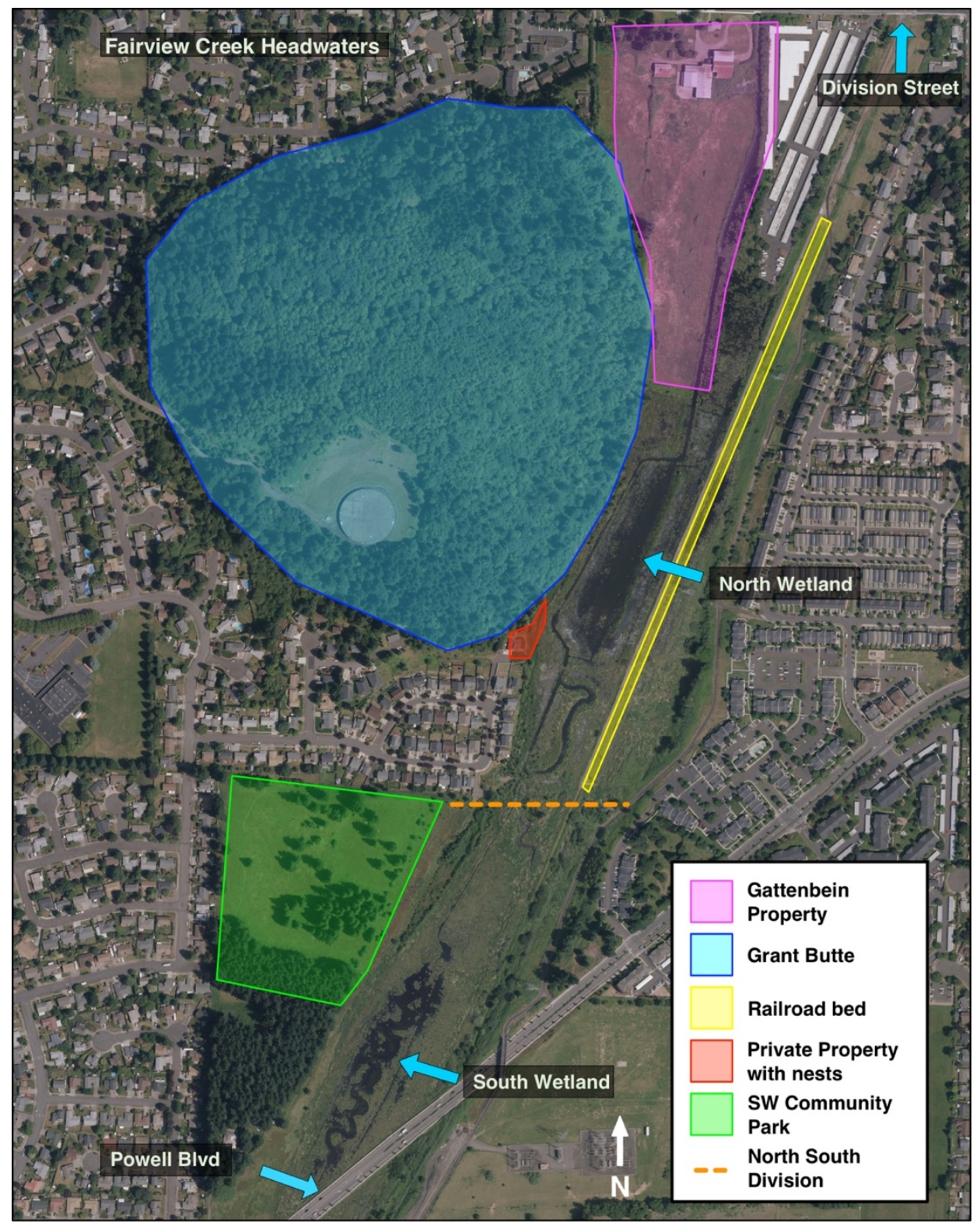

Figure 1.3. Map of Fairview Creek Headwaters prominent features. 
Site History

In survey maps from the 1850 s, as well as some oral history records, the site had very little standing water, but rather very high groundwater with flow events occurring in large flood events. In 1865, Thomas Grant homesteaded the butte and wetlands. By 1870, drainage ditches had begun to be built to remove water from the land so it could be used for cattle grazing. These ditches were maintained into the mid-1900s as part of the grazing operations (Figure 1.5). In 1937, the ditch was renamed to Fairview Creek, but was still considered by landowners as "the ditch." In 1948, Henry Gantenbein bought the north end of the property and started a dairy farm (Darlene Gantenbein-Grimm, personal communications, 2014). The dairy operations continued through 1990 when the farm was sold to Holsteins, Gantenbein's son-in-law. At that point, Holsteins used the farm for beef cattle. Grazing continued until Gantenbein's death in 2003.

In the 1970s, the butte was developed and included a 102-home subdivision built on the southwest side of the butte in starting in 1978 (Figure 1.4). This development continued through the 1980s and 1990s (Figure 1.7). There was interest in developing the top of the butte, but the city denied plans and instead preserved it as a natural area (Figure 1.6). In 1990, the city purchased Southwest Community Park (37 acres) which included 17 acres of wetlands.

Several restoration projects have taken place in the past 20 years at $\mathrm{FCH}$, primarily focusing on repairing the hydrology and vegetation at the site. These projects have ultimately restored a portion of the creek to a 37.58-acre wetland. In 1993, two lateral ditches in the southern end of the site were reconstructed into a meandering channel. The goal of the project was to enhance the degraded wetland and to diversify wildlife habitat through re-establishing the vegetative community (800 trees and shrubs were planted). From 1995-1997, work in this area of the wetland was expanded to include community planting events. In 2002, a new channel was constructed in the central area of the site. This was part of a required regulation mitigation project to compensate for eight acres impacted by the Gresham Shopping Square.

In 2008, a regional trail, the Gresham Fairview Trail, was built along the entire east boundary of the wetland. This trail is significant because it was originally proposed to be constructed on the abandoned railroad bed in the middle of the wetland, but was moved to the east boundary after discovering the turtles were using of the railroad bed for nesting.

The Gantenbein Dairy property, in the northwest corner of the site, was purchased by Metro, City of Gresham, and East Multnomah Soil and Water Conservation district in 2014. This 32.8-acre site is an ideal area to focus additional habitat creation for turtles due to its size and proximity to existing wetland and turtle habitat. 


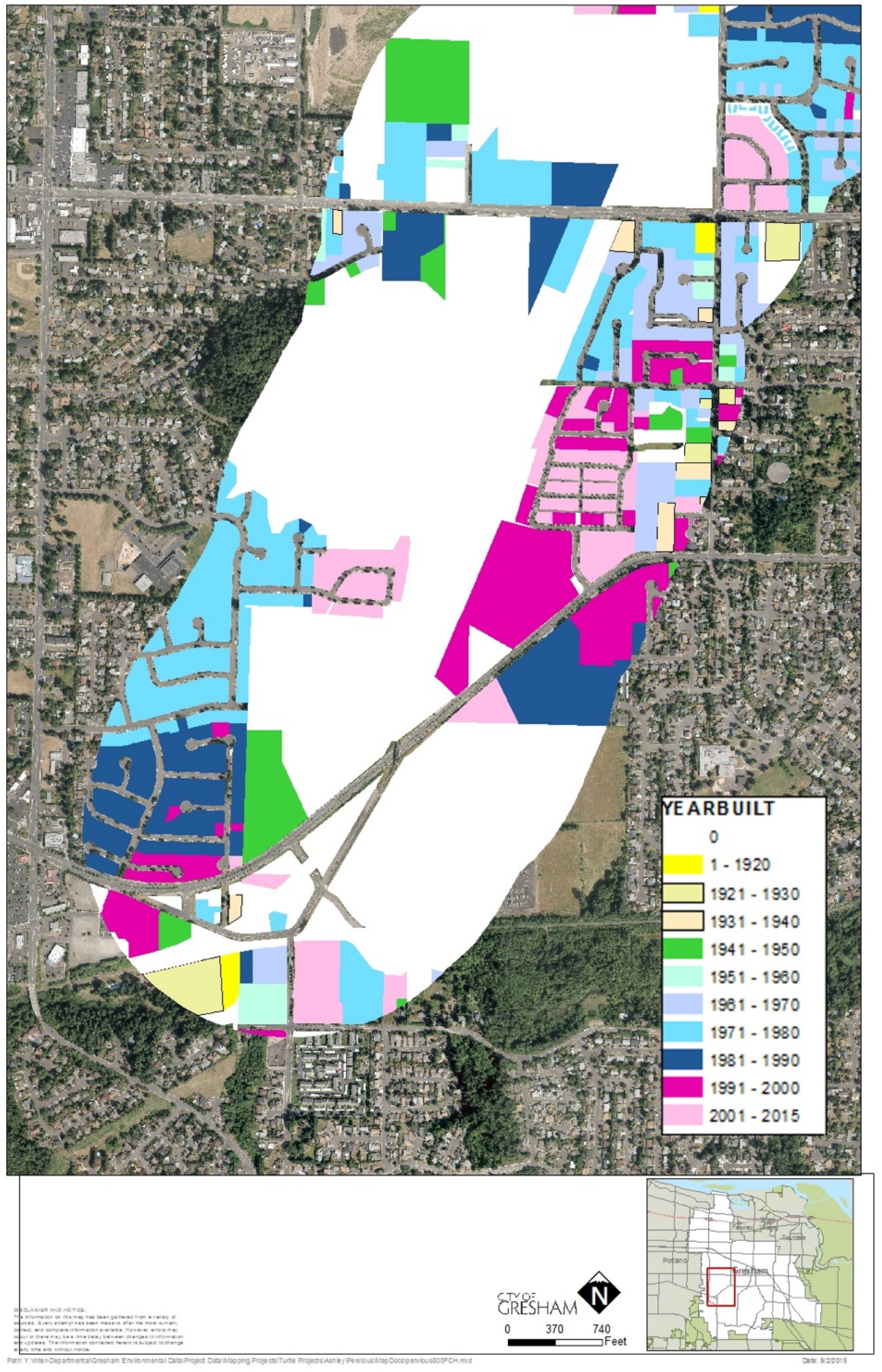

Figure 1.4. To understand the increases urbanization over the years, this map shows the decade that houses were built within a 500-meter buffer of the wetland. On the south west corner of the butte many of the houses were built in 1970s, 80s and 90s. 


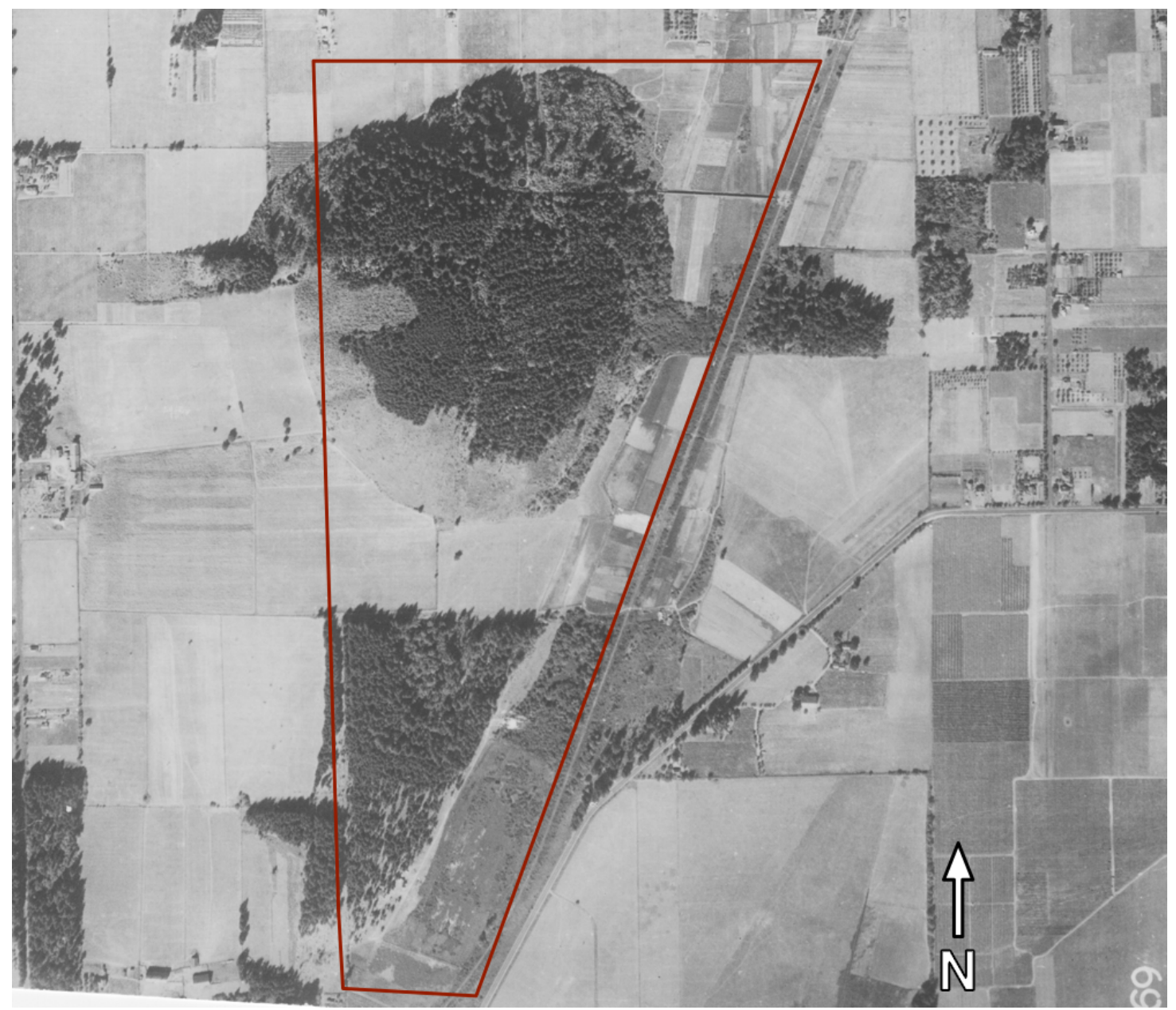

Figure 1.5. This 1935 map shows Grant Butte with agricultural land all around it. The wetland was drained into the ditch (Photo: City of Gresham). 


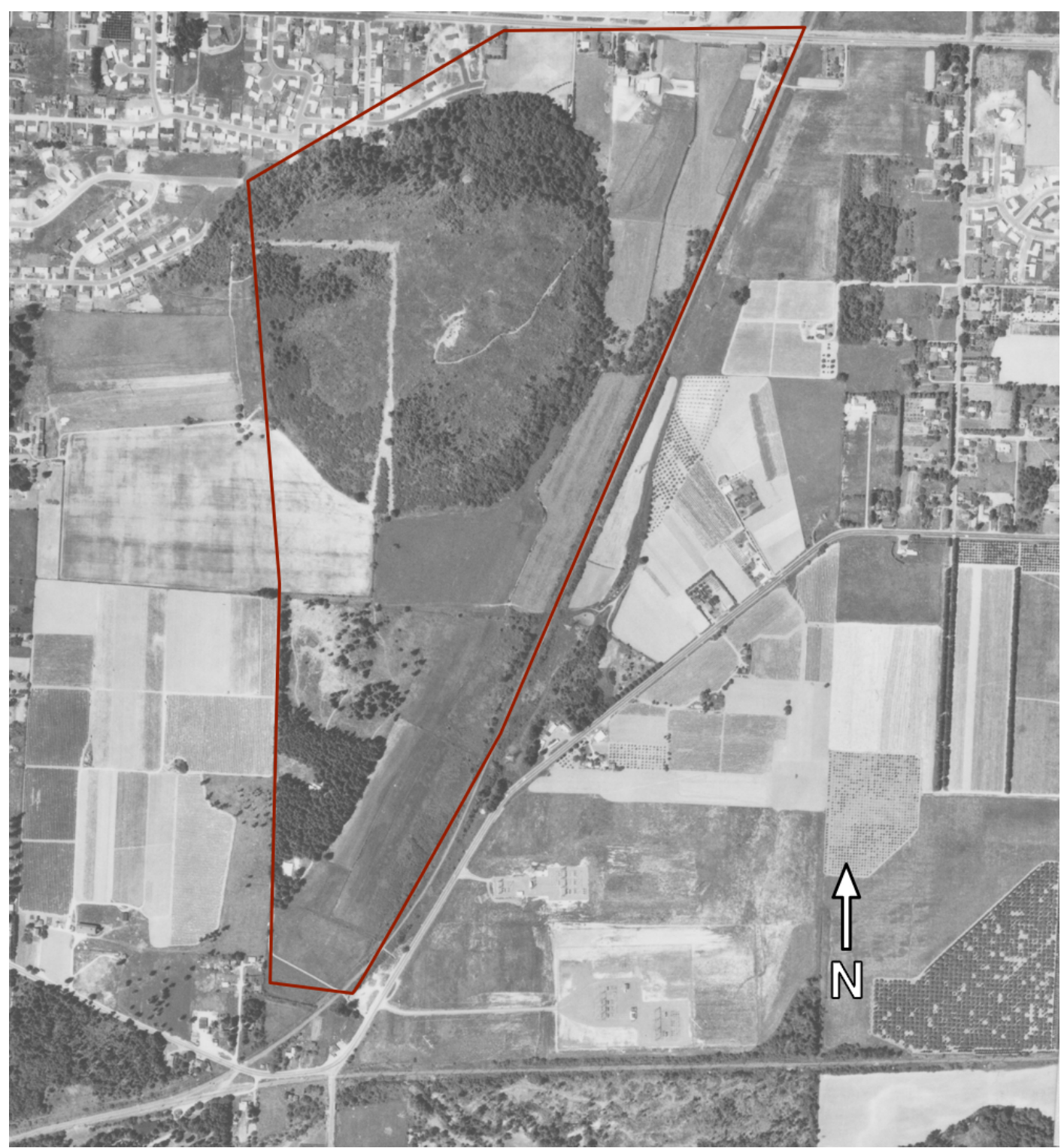

Figure 1.6. By 1963 when this photo was taken, much of the land northwest of the butte had been converted to residential land. Additionally, residential land to the east is getting closer to the butte. Logging operations taking place on the butte can be seen (Photo: City of Gresham). 


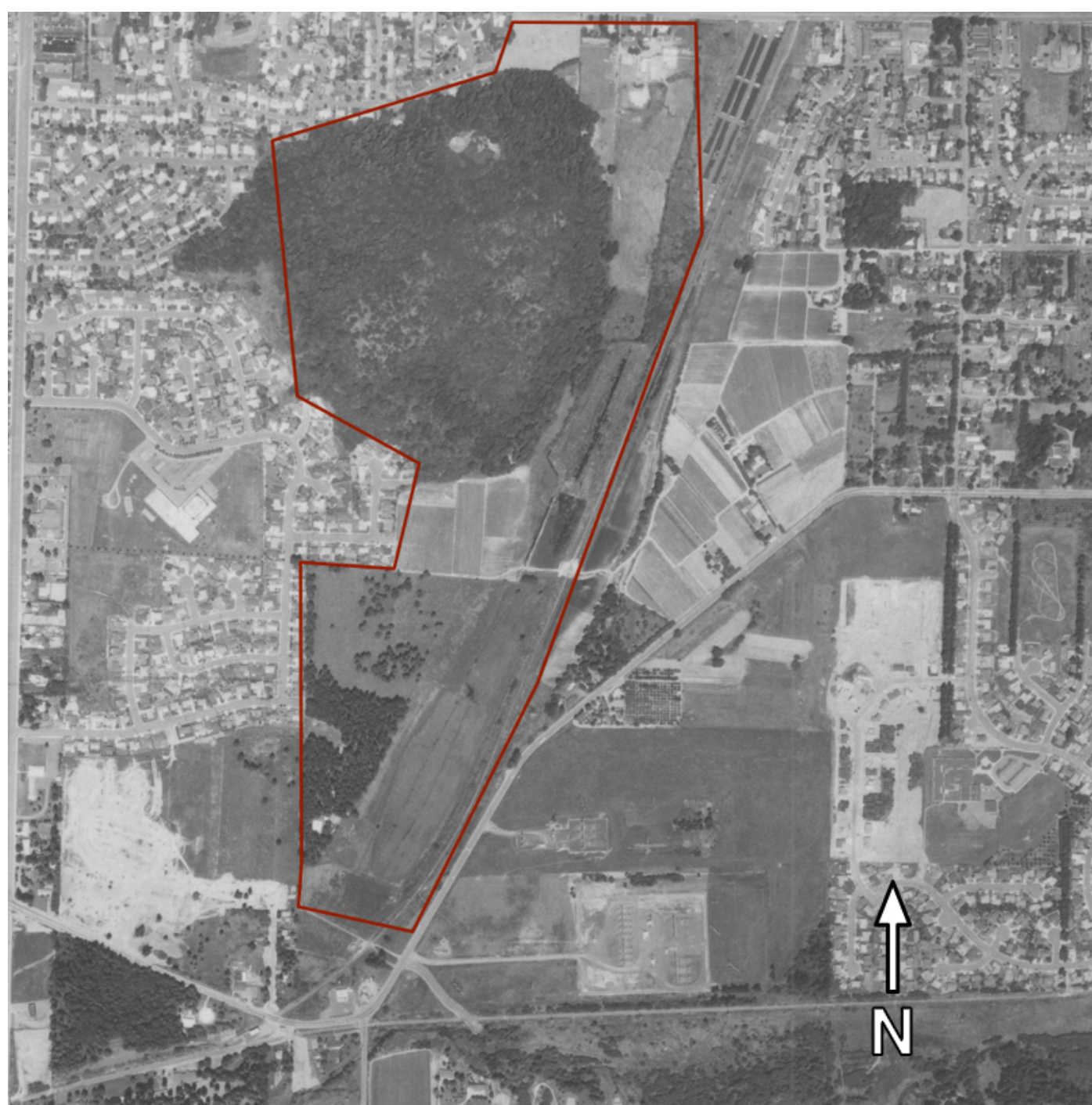

Figure 1.7. By 1984 many of the subdivisions had been built on the west and southwest side of the butte. The subdivisions on the east end of the site are encroaching on the site, but there is still farmland in between the subdivisions and Fairview Creak Headwaters (Photo: City of Gresham).

\section{City Use}

The site is one of the natural areas found within the city. On the southwest end of the site there is a 34.1-acre city park (Southwest Community Park; Figure 1.3). This natural areas park is often used by dog walkers. There is also a water quality facility near the park on the west edge of the wetland used to control storm water runoff from neighboring subdivisions. Additionally, there is a 10-milliongallon water reservoir on the top of the butte, the Grant Butte Reservoir. The city views FCH as a valuable area for protecting wildlife, plants, and water resources in the urban context. In order to protect the wildlife using the area, there have been 
several signs posted around the wetland encouraging the public to keep out of the wetland and keep on designated trails, including the Fairview-Gresham Trail.

Species: Western Painted Turtle (Chrysemys picta bellii)

The western painted turtle (Chrysemys picta bellii) is a native turtle found at Fairview Creek Headwaters. It is one of two native turtles in Oregon, the other being the western pond turtle (Actinemys marmorata). As a native species to Oregon, the city has prioritized this species, particularly the population at Fairview Creek Headwaters, as one they need to preserve.

\section{Range}

Painted turtles (Chrysemys picta) are found throughout North America, with the largest range of any freshwater turtle in North America (Van Dijk 2013). Their range extends from the Atlantic to Pacific coasts (Figure 1.8). They can be found in a variety of habitats ranging from small ponds and wetlands to large river systems (Cagle 1954; Rowe 2003), in both natural and urban sites. Although found in a wide variety of habitats, slow moving water is critical to the species (Cagle 1954).

A subspecies of the painted turtle, the western painted turtle (C. picta bellii) is a small freshwater turtle. Their range extends from British Columbia to California, and eastward to the central U.S. (Gervais et al. 2009, Barela and Olson 2014; Figure 1.9). However, the species is considered to be non-native in California (Spinks et al. 2003). In Oregon, they are found north of Salem, most abundantly near the Columbia River (Rosenberg and Gervis 2012) and throughout the northern portion of the Willamette Valley. The population found at FCH is one of the largest populations of western painted turtles found on the east end of the Willamette Valley. 


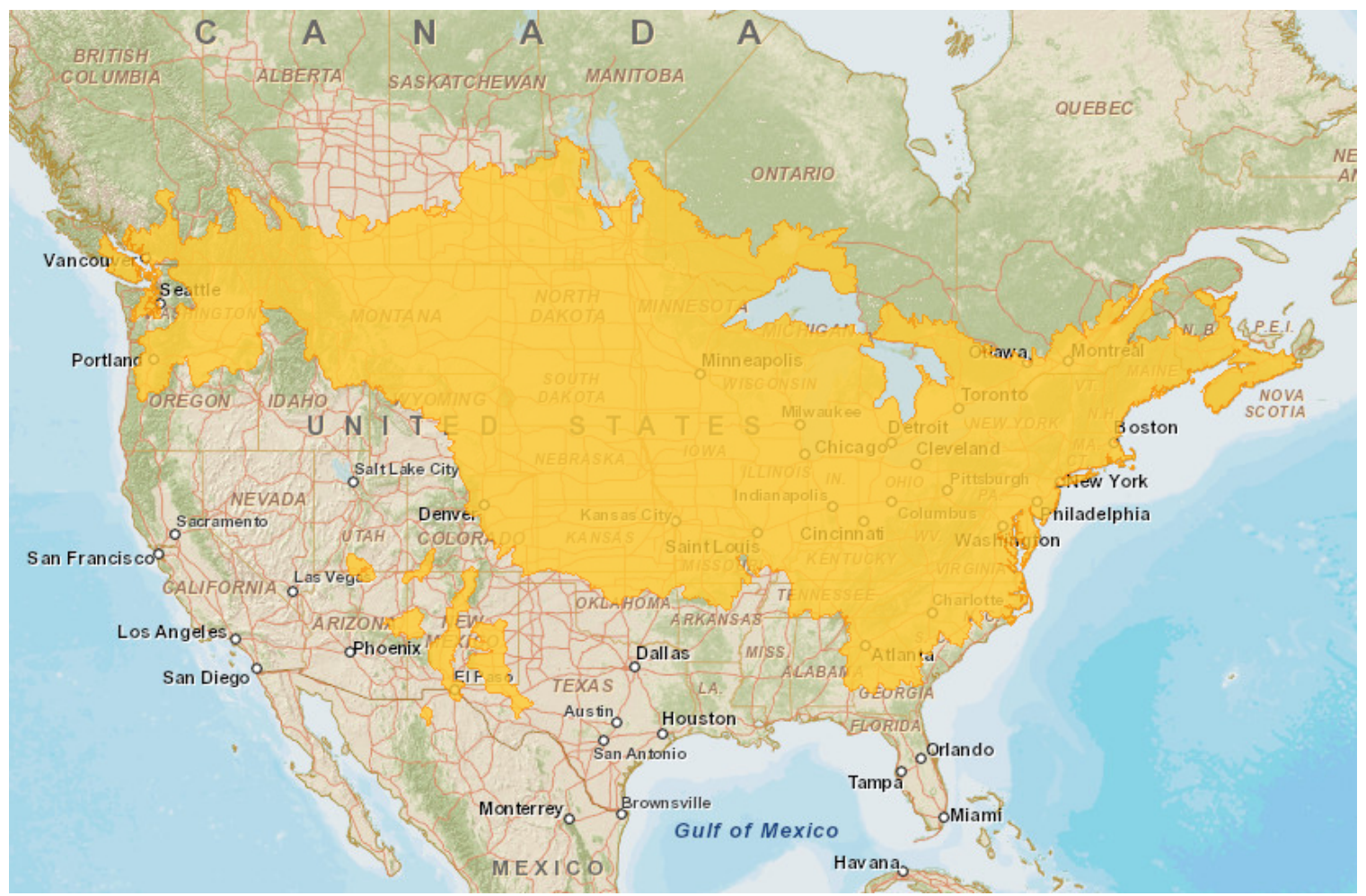

Figure 1.8. Map of distribution of all painted turtles in North America. Taken from the IUCN Red List species range maps (CRF 2013). 


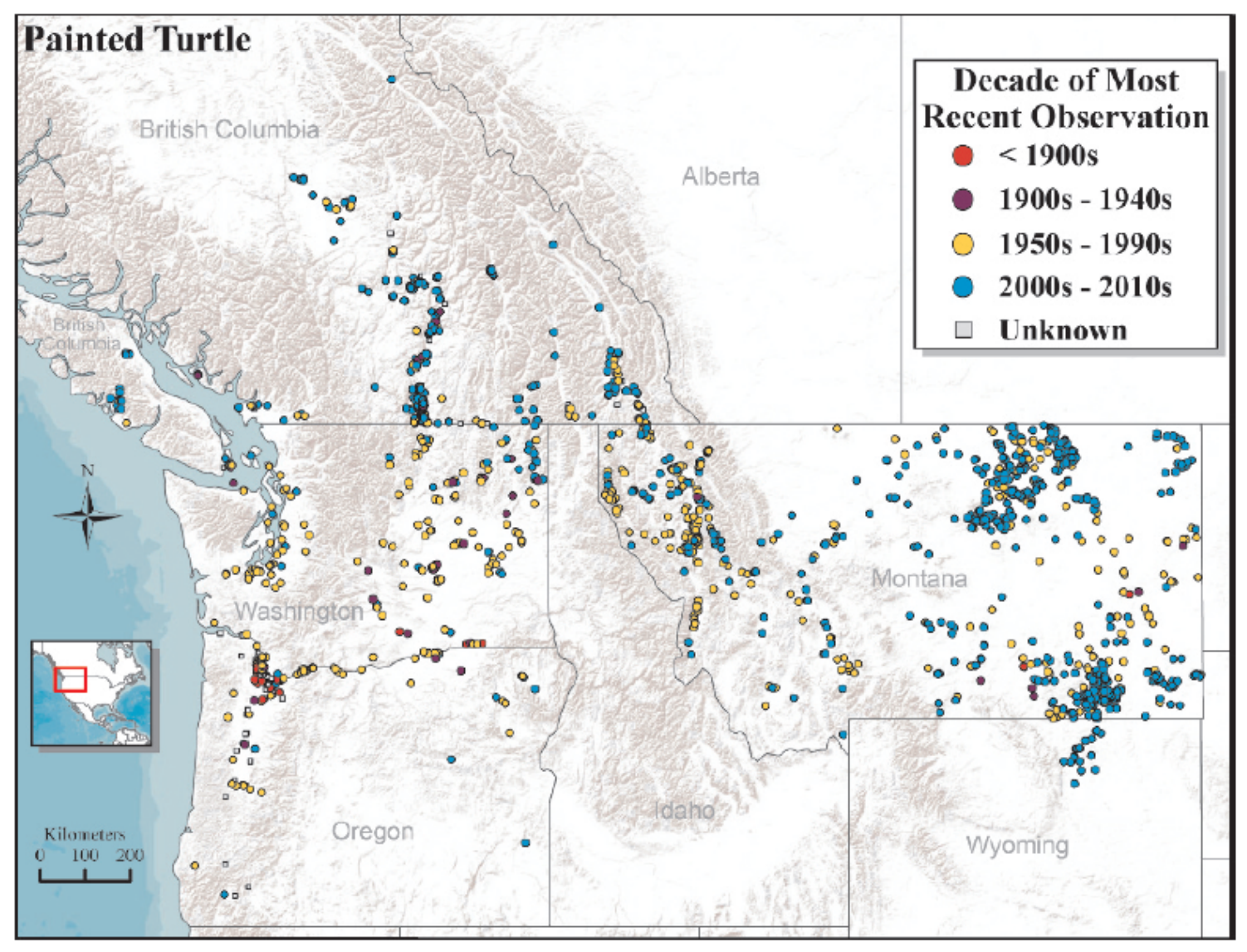

Figure 1.9. Barela and Olson 2014. Range of Western painted turtles in the Pacific Northwest.

\section{Description}

The western painted turtle (C. picta bellii) is a colorful turtle with yellow, orange, and red stripes along the arms, legs, and neck. The plastron (belly shell) is distinguished by a colorful black pattern on a red background. The carapace (top shell) is a drab to olive green and up to $25 \mathrm{~cm}$ in length (Ernst and Lovich 2009). The carapace has smooth edges with 12 outer scutes (boney plate on shell of a turtle) on each side of the shell; though this can sometimes vary with malformations on the turtle (Figure 1.10).

The species is typically divided into three different stage classes: hatchling, juvenile, and adult (Cagle 1954) based on age. Using annuli (age or growth rings) found on the plastron and the carapace, an approximate age of the turtle can be determined (Sexton 1959). While the number of annuli is often used as a measure of age, many have found it to be unreliable and instead recommend using the length of the shell to determine the age of the turtles (Gibbons 1968a, Wilson et. al 2003).

Males become sexually mature between three and four years of age (Lindeman 1996), while females do not mature until they are between seven to nine years old (Lindeman 1996; Iverson and Smith 1993; Zweifel 1989; Wilbur 1975; 
Tinkle et al. 1981; Mitchell 1985). Some studies found that sexual maturity was not tied to age but rather size (Gibbons 1968a, Moll 1973, Lindeman 1996). Furthermore, sexual maturity has been found to be correlated to plastron length and differs from male to female. Females became sexually mature upon reaching a plastron length of 12-13 cm (Cagle 1954) or $16 \mathrm{~cm}(160 \mathrm{~mm})$ according to a study done by Lindeman (1996). Males reach maturity at about $9 \mathrm{~cm}$ (Cagle 1954; Lindeman 1996). Reaching maturity based on plastron size may vary by region. Knowing the age of the turtle can assist in determining the sex of the individual and whether or not it is sexually mature, but these are not absolutes. Tail size and claw size can help distinguish males from females. Males and females vary in size with males generally being smaller (Ream and Ream 1966; Lindeman 1996). Males often have longer nails (or claws) on their fore feet (Cagle 1954) and have a wider tail at the base than females. The carapace differs between male and female, with male turtles having a lower slender profile shape. The female's carapace is higher domed and more rounded in appearance. The plastron is flat to slightly convex.

Red-eared sliders (Trachemys scripta elegans) are often confused with western painted turtles. This non-native species can be distinguished from the painted turtle by the single red stripe up its neck found behind the eyes. The plastron of the redeared slider is typically lighter and yellow with black blotches. The carapace has serrated edges on the red-eared slider compared to the smooth edges on the painted turtle. While similar in size, the red-eared slider can grow slightly larger in size, 29 $\mathrm{cm}$ in carapace length compared to the painted turtle's $25 \mathrm{~cm}$ length. 


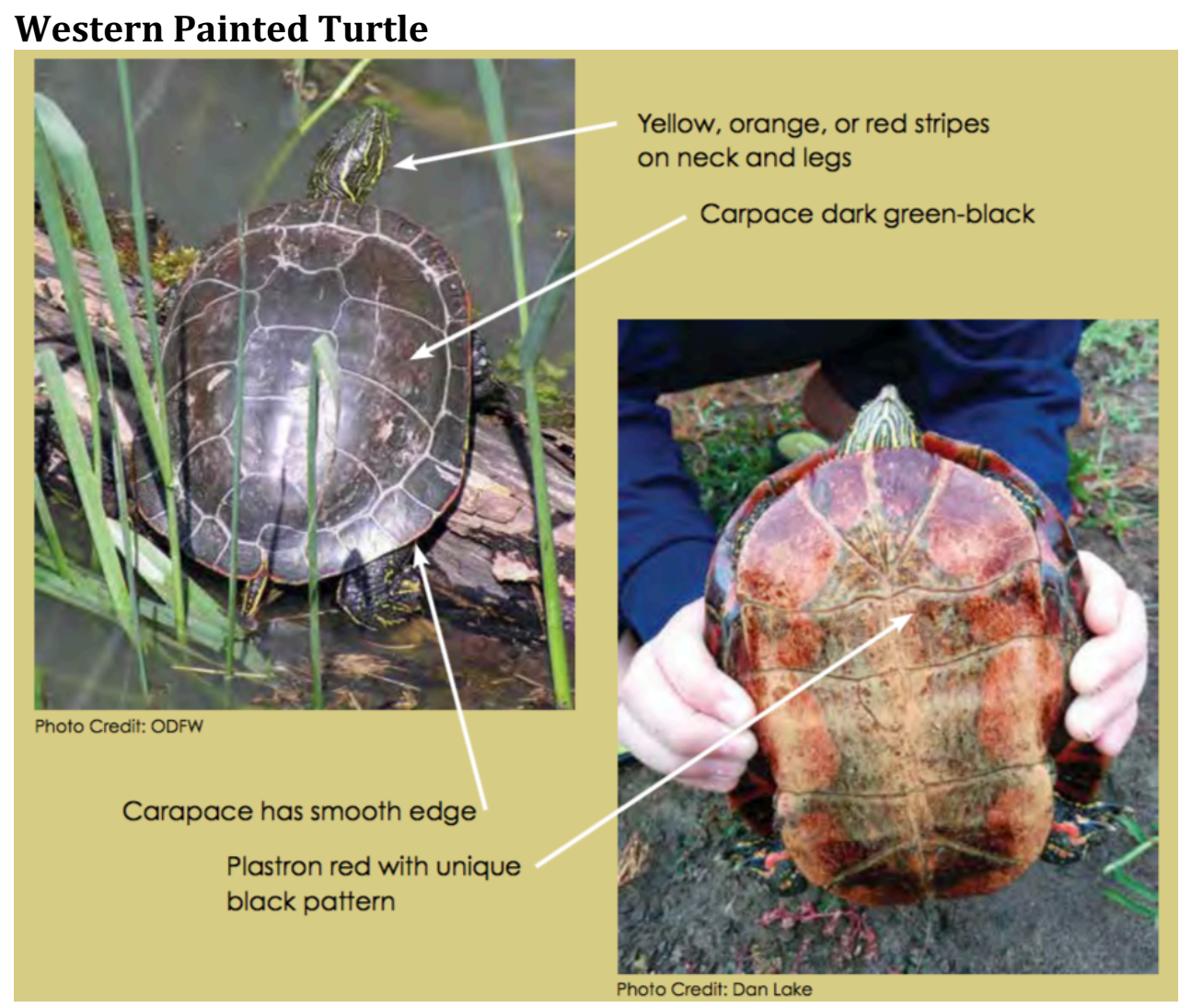

\section{Red-eared slider}

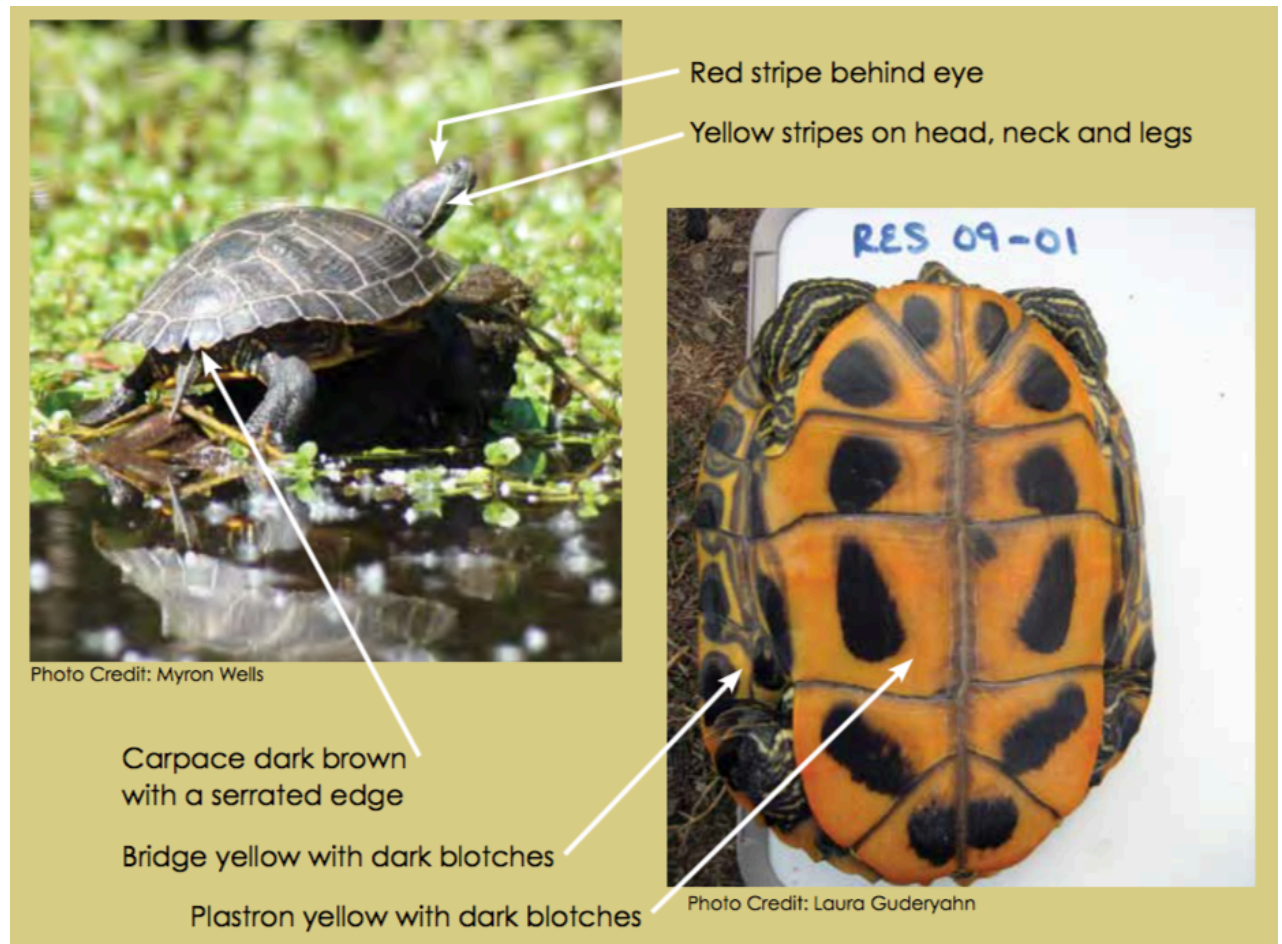

Figure 1.10. Comparison of the native western painted turtle (top picture) with the non-native red-eared slider (bottom picture). Taken from the ODFWS Turtle BMP (2015). 


\section{Life History Characteristics}

Painted turtles (Chrymys picta) emerge from winter hibernation in the early spring (March-April) and start basking, foraging, and engaging in courtship as the weather warms (Ernst 1971; Rowe 2003). Starting in May female turtles begin nesting (laying eggs in the nest they excavate in the ground) with the peak nesting season being in June and ending in early July (Congdon and Gatten 1989). Nests are usually laid within $100 \mathrm{~m}$ of the wetland's edge. One study in Michigan found the average nest to be $60 \mathrm{~m}$ from the waters' edge (Congdon and Gatten 1989). Nests typically include between 2-11 eggs per nest (Cagle 1954), but up to 15 can be found (Smith 1950). Eggs are incubated in sunny soil for approximately 72 days (Koonz 1998). The temperature of egg incubation is a determiner of turtle gender with warmer temperatures producing females (Ewert and Nelson 1991). Hatchlings usually emerge from the eggs in September or October and then either stay in the nest until they emerge from the nest the following spring (almost a year later; Nichols 1933, Hartweg 1944) or emerge from the nest in the fall and enter the adjacent water where they overwinter (Koonz 1998). At the FCH site, some hatchlings have been found to emerge from nests in the fall of the same year as being laid. Survival rates in hatchlings are typically very low because of high risk of mortality due to predators (raccoons, coyotes, cats, etc.) destroying nests and the difficulty of surviving winter temperatures (Christiansen and Gallaway 1984; Nagle et al. 2000). Once the hatchlings emerge from the nest and enter the water they are considered juveniles at about one-year-old. They remain in this stage until maturing into adults, which is 4 years for males and 7 years for females (Iverson and Smith 1993; Zweifel 1989). Larger female turtles are known to be able to nest more than one time during a season (Ernst 1971). This ability means the fecundities are different for large and small adults. An adult will continue to reproduce until death, averaging one nest per year. Western painted turtles are known to be long-lived individuals with both sexes living between 15 to 30+ years (Gibbons 1968b).

\section{Conservation Status}

Even though painted turtles are widespread, the subspecies C. picta belli is listed with varying degrees of management status by state and federal agencies. The US Forest Service and the Bureau of Land Management in Oregon list it as a sensitive species. The Oregon Department of Fish and Wildlife's Conservation Strategy (ODFW 2006) has targeted the species as one to monitor and lists it as a species of concern, with the designation of sensitive to critical. The species is not listed in Washington. British Columbia has listed it as endangered in its Pacific Coast population and as a species of special concern in its Rocky Mountain population (COSEWIC 2006). The western painted turtle does not have a national designation by the US Fish and Wildlife Service because of the broad distribution throughout North America. Locally, however, the species faces many threats. 
Understanding the habitat needs of turtles in urban environments (discussed in Chapter 2 and 3) is critical where there is limited habitat. Protection of these critical areas and conservation of the populations using them will be vital to maintaining this species in the face of increasing human populations and urbanization (McKinney 2006). 


\section{Objective}

\section{Chapter 2: Habitat}

Focusing on three critical habitat types (basking, nesting and overwintering) the objectives of the habitat section is as follows:

- Use findings from literature to assess the habitat needs for turtles at FCH

- To understand why the turtles are using particular areas

- To characterize the current habitat

- To make informed management decisions

Literature Review: Habitat needs

Threats

Turtles are able to persist in urban environments despite the many anthropomorphic pressures unique to urban systems that impact their survival (De Lathouder et al. 2009). Humans are the direct and indirect cause of much of the destruction to aquatic and terrestrial habitat through polluting and altering these systems (Klein 1979; Moyle and Leidy 1992; Trombulak and Frissell 2000). Actions such as replacing wetlands with development, removing downed woody debris in wetland that could be used as basking structures, and removing natural leaf litter and wood debris from uplands which can be used by turtles for hibernation and predator avoidance, are all things that degrade quality turtle habitat.

Continuous disturbance of an area by human activity, pets or introduction of non-native species impacts the behavior and habitat use by turtles. Pets, such as domestic dogs and cats, act as predators of both adult turtles as well as hatchlings through nest predation (Broderick and Godley 1996; Leslie et al. 1996). This risk of predation causes turtles to continually avoid areas for basking or causes interruption in basking time (Marchand and Litvaitis 2004a). Humans are also often tied to the introduction of non-native animal species (Lambert et al. 2013; Cadi and Joly 2003), which can compete for limited basking and feeding areas. Introduced plants may alter the ecosystem which can impact: water quality, plant density, and available basking and nesting habitat for turtles. Finally, recreational activities such as boating or vehicular traffic on nearby roads (Failey et al. 2007; Garber and Burger 1995) have been shown to have a significant effect on turtle basking time (Moore and Seigal 2006). These disturbances may cause turtles to avoid portions of a site or even to leave the site altogether, forcing them to spend more time on land, where rates of predation or injury are higher (Steen and Gibbs 2004; Spencer 2002; Christiansen and Gallaway 1984; Garber and Burger 1995; Marchand \& Litvaitis 2004a; Temple 1987). Furthermore, habitat loss and fragmentation in urban areas have been found to result in increased rates of predation (Andrén and Angelstam 1988; Brown et al. 2012).

Freshwater turtles, such as the western painted turtles, need both upland and aquatic habitats for various stages of their life cycle. Western painted turtles use aquatic habitat primarily for basking and feeding at Fairview Creek Headwaters. 
Adjacent upland, such as Grant Butte and surrounding upland at FCH, is used for nesting, overwintering and potentially basking as well (see Figure 2.1 for location of all habitat types at FCH).

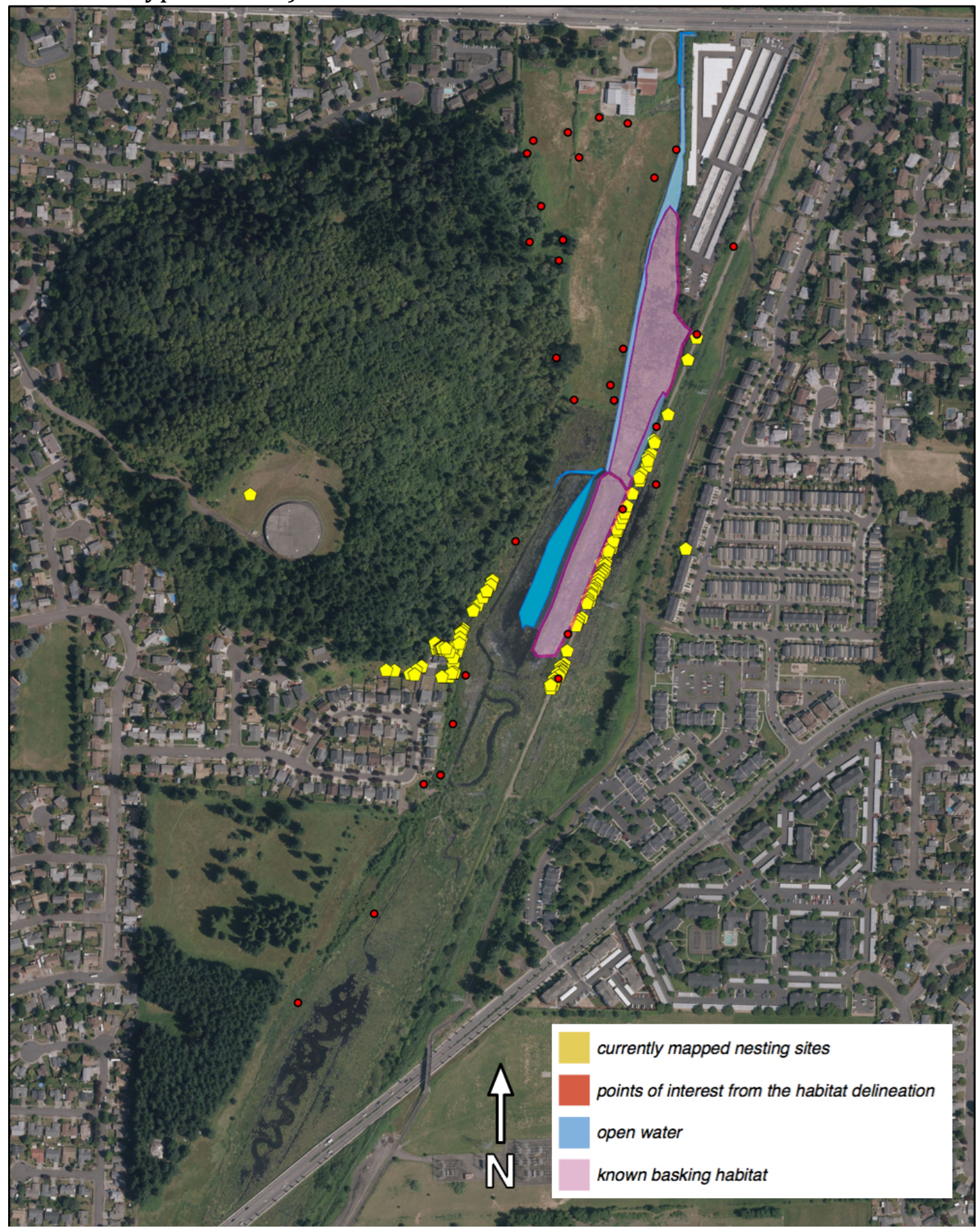

Figure 2.1. Fairview Creek Headwaters and Grant Butte site. Pink polygon represents known basking habitat for western painted turtles. Yellow dots are all known nesting locations from seven years of monitoring. The line of nests on the right side of the map are found along an old elevated gravel railway bed. The blue polygon highlights areas of deep open water (in north) with the northern most end being more channelized. The red dots are areas of important habitat features for turtles and site locations noted in a habitat delineation done in the fall of 2014. 
Aquatic Habitat

The general aquatic habitat type that this species prefers includes slow moving waters such as sloughs, ponds, streams, rivers and lakes. Aquatic vegetation found at the site is important for feeding, refugia and thermoregulation (Meseth and Sexton 1963; Rosenberg and Gervis 2012). Western painted turtles must be underwater in order to swallow (Lagler 1943a); thus adequate aquatic habitat is essential. Knight and Gibbons (1968) as well as Klemens (1993) found that eutrophication in urban ponds might benefit freshwater turtles by adding additional floating and emergent vegetation which provides refugia and protection from predators as well as increased food. Water temperature can act to regulate vegetation found in ponds and therefore act as a potential determinant of western painted turtle's habitat selection (Rosenberg and Gervis 2012). While western painted turtles use aquatic habitat for a variety of different things (e.g. feeding and refugia), the most critical aquatic habitat types are basking habitat and overwintering.

\section{Basking habitat}

Basking is a necessary behavior that aids in digestion and metabolic rates (Hammond et al. 1988), improves reproductive success in females for egg production (Carrière et al. 2008), and assists in general thermoregulation in ectotherms (Boyer 1965; Auth 1975; Schwarzkopf and Brooks 1985). Body size, shape and color are biological factors that influence the amount of heat absorbed by the animal (Boyer 1965). Basking behavior in turtles is a response to the pattern of solar heat available (Cadi and Joly 2003). Turtles have been observed moving to different basking locations based on availability of sunlight (Umphrey et al. 2012; Krawchuk and Brooks 1998). Generally, more females are seen basking than males during the spring and early summer (Carriére et al. 2008), presumably because females use heat energy absorbed during basking in egg development of already fertilized eggs. This seasonal pattern of basking is somewhat controversial. Some studies have found that females do bask more in seasons when ovipositing (Hammond et al. 1988; Moore and Seigel 2006), others found no difference in basking seasonality and length of time between males and females during the rest of the year (Manning and Grigg 1997). Krawchuk and Brooks (1998) also were not able to find a correlation between basking behavior and egg development. The seasonal patterns and length of time basking requires further study as other unstudied reasons may be attributing to the resulting observed differences.

Equally as important as the availability of the sun is the amount of cover provided for the turtle around basking locations. Herbaceous and grass cover provides protection from predators and a place for cooling so turtles do not become overheated. The role of herbaceous cover is especially important along shoreline basking sites; De Lathouder et al. (2009) found a positive correlation between number of turtles and herbaceaous cover. Placement of artificial basking structures in the site is very important. Basking on the edge of wetlands is dangerous due to 
increased chance of encountering predators and humans (Spink et al. 2003), especially if there is a lack of herbaceous cover. Placement of basking structures in the middle of water bodies offers protection from some predation. Furthermore, continual disturbance causes turtles to avoid areas (Moore and Seigel 2006). For instance, turtles use of basking structures decreases when they were located near roads due to the increased disturbance caused by roads (Failey et al. 2007).

Spink et al. (2003) noticed that removal of basking locations (both artificial and natural) from a site lead to a decline in recruitment (new individuals added to the population through birth and/or immigration). Artificial basking structures commonly made from PVC pipe, boards or a pallet are typically used as ways to increase basking habitat (Umphrey et al. 2012). Umphrey et al. (2012) found great success with their basking log design, consisting of reclaimed wood and blocks of Styrofoam, which mimics natural logs.

\section{Overwintering habitat}

Habitat available for the overwintering of freshwater turtles is an important part of their life cycle. During the winter months turtles hibernate (or overwinter) in either the bottom of a pond or buried into duff and litter in the upland forests. During hibernation, a turtle's core temperature is lowered to ambient temperatures, metabolic rates decrease, and they live off stored fat reserves and oxygen already saturated in their blood (Moon et al. 1997). They stay in this state until emergence which is triggered by at least three days of warm air temperatures (above 60F). Low water temperatures and high levels of dissolved oxygen have been found to be important factors in site selection of aquatic overwintering habitat (Herbert and Jackson 1985; Rollinson et al. 2008; Ultsch and Jackson 1982). Low water temperatures lower a turtle's metabolism as well as delay the onset of acidosis (Herbert and Jackson 1985; Rollinson et al. 2008). Furthermore, turtles are able to take up oxygen through extrapulmonary means (through their skin), higher levels of DO help reduce the build-up of acid in their blood (Rollinson et al. 2008; Ultsch and Jackson 1982; Jackson et al. 2004). Ways to manage the water temperature and dissolved oxygen in the aquatic habitat should be considered to maximize turtle overwintering habitat and provide the best conditions for hibernation.

Painted turtles overwinter both in aquatic and terrestrial habitats (Gervais et al. 2009) but are more likely to use aquatic habitat for overwintering. In the Willamette Valley, turtles found in ponds or slow moving backwaters were more likely to hibernate underwater (Holland 1994; Davis 1998; ODFW 2015; Gervais et al. 2009). During the winter, cold temperatures cause the turtles to go into brometion (hibernation like state in reptiles), burying themselves in the substrate of wetlands and ponds (Hayes et al. 2002; Koonz 1998; ODFW 2015). The substrate of ponds and streams that turtles bury in is loosely compacted mud and/or decomposing organic material (Holland 1994).

If they do use terrestrial habitat they will take cover in shrub and leaf litter, digging into the top layer of duff (ODFW 2015). Both upland duff and aquatic mud 
habitats allow turtles to be protected from predators during hibernation. It is important in the urban environment to have both upland and aquatic overwintering habitats available to turtles. Often wetland buffer requirements do not allow for enough upland habitat, which can be critical for maintaining a turtle population (Burke and Gibbons 1995; Semlitsch and Bodie 2003). In this study upland habitat is considered anything that is terrestrial habitat, dry habitat that is not submerged by water for a portion of the year.

Upland Habitat

Terrestrial or upland habitat is used for basking, nesting, aestivation and overwintering by freshwater turtles. Females leaving the aquatic habitat to build a nest (nesting) is one of the primary uses of upland habitat by western painted turtles in the Willamette Valley (Gervais et al. 2009).

\section{Nesting habitat}

Many of the threats to turtle nesting habitats are similar to basking habitat. One of the largest limitations to turtles in urban areas is the availability and location of suitable nesting habitat. Nesting habitat is essential for reproduction and general fecundity of the species. Maintaining adequate nesting habitat as well as creating new nesting habitat for turtles can be very challenging within small fragmented areas. Sites without appropriate habitat may have lower recruitment rates and potentially skewed age classes and sex ratios. Furthermore, the placement of nesting habitat is important to decrease nest predation and limit road crossing by adults looking for nesting habitat.

Females lay their nests from April to late July (Cagle 1954). The eggs typically hatch out and then hatchlings overwinter underground in the nest and start emerging in March (Nichols 1933, Hartweg 1944) or emerge in the fall and spend the winter in the water (for more information, see Chapter 1: Introduction). Ideal nesting habitat should consist of areas of bare ground or minimal to short vegetation (<6inches), with sandy-loam soil (ODFW 2015). Solar exposure is very important to egg development and hatchling survival (Janzen 1994); a south-tosouth eastern facing slope is recommended. Maintaining proper vegetation and bare ground so adult female turtles can dig nests and so the hatchlings can emerge the following spring (or fall) is critical to hatchling recruitment. Nesting areas should be slightly elevated to protect from seasonal flooding (Lenhart et al. 2013) but close enough in proximity to the water's edge to limit predation on adult females and hatchlings as they move to and from the nest to the water. Western painted turtles' nests were typically found within $100 \mathrm{~m}$, but as far as $275 \mathrm{~m}$, from the water's edge (Marchand el al. 2002, Burke and Gibbons 1995). Nest predation by coyotes (Canis latrans), raccoons (Procyon lotor), opossums (Didelphis virginiana), dogs and cats is especially common in urban areas (Leslie et al. 1996).

Proximity to roads is one of the greatest threats to nesting freshwater turtles 
in urban areas (Failey et al. 2007). Mortality to females is greatest when nesting habitat is located next to a road, on a road, or if nesting habitat and aquatic habitat are bisected by a road. Often times if there is not sufficient nesting habitat next to the aquatic habitat, females will travel farther, often across roads in search of a place to nest (Baldwin et al. 2004). Soils next to roads are often a sand and gravel mix that is attractive habitat for nesting turtles. Furthermore, depending on the orientation of the road, sun exposure is ideal for nesting adjacent to the road. These areas can also provide basking habitat (Aresco 2005). Females searching for suitable habitat on the edge of roads (Steen and Gibbs 2004) are vulnerable to being killed by cars, attacked by predators or taken by humans.

\section{Current Status of Basking and Nesting habitat at FCH Current status of basking habitat at $\mathrm{FCH}$}

Turtles were observed basking on mud mounds, small islands and manmade basking structures throughout the northern end of the site (Figure 1.3) from March to September. In the spring when the water levels are higher, the turtles were more often observed basking on islands (or mud mounds) in the northern section of the wetland (Figure 2.2). By the late summer and fall the water levels decreased and turtles were observed basking piled on manmade basking structures located in the middle of the large main open- water wetland in the north. These manmade structures were placed at the site starting in 2008 to increase basking habitat availability. Hayes et al. (2002) noted similar basking behavior; turtles were found basking in deep permanent water bodies when other water bodies had dried up. No turtles were observed using the edge of the islands to bask on in late summer as they had been earlier in the spring. Vegetation on many of the islands was more over grown then in the spring and some of the islands became surrounded by muddy water or thick mud. In the late summer there are limited basking areas for turtles as much of the islands were over grown and logs that were floating a month earlier are now on dry land or mudflats. The availability of basking structures in or near the edge of the water, presents challenges for turtles, especially when limited by increased mudflats and dry land. If basking structures are too far from the water, turtles basking on those structures may be more susceptible to predators.

Beavers (Castor canadensis) , river otters (Lutra canadensis) and nutria (Myocastor coypus) are also seen at the site regularly. Beavers have created channels as well as felled some trees in the northern section of the wetland. The edges of the site however have few large trees and are instead dominated by small willows and shrubs (especially true at the southern end of the large open water wetland). The lack of large trees near the edge means there are few natural floating logs in the water for turtles to use for basking, thus the need for manmade floating structures (see basking habitat section).

A total of 16 manmade basking structures have been placed at Fairview 
Creek Headwaters (Figure 2.2), with the earliest structures being installed in 2008. Eleven of the structures are found in the north end of the site (Figure 2.3) and five in the southern channel. In multiple years of basking surveys, turtles have only been spotted basking on the eleven structures in the northern channel, with most of the basking taking place on structures one (FCH_T_1) through nine( $\left.\mathrm{FCH}_{-} \mathrm{T}_{-} 9\right)$, all located in the southern part of the deep open water. All the platforms were made using the same instructions (see management plan/appendix), made out of three inch ABS pipe and cedar fencing. Umphrey et al. (2012) found success with a composite design platform log, but also found that any addition to basking habitat would enhance the population. 


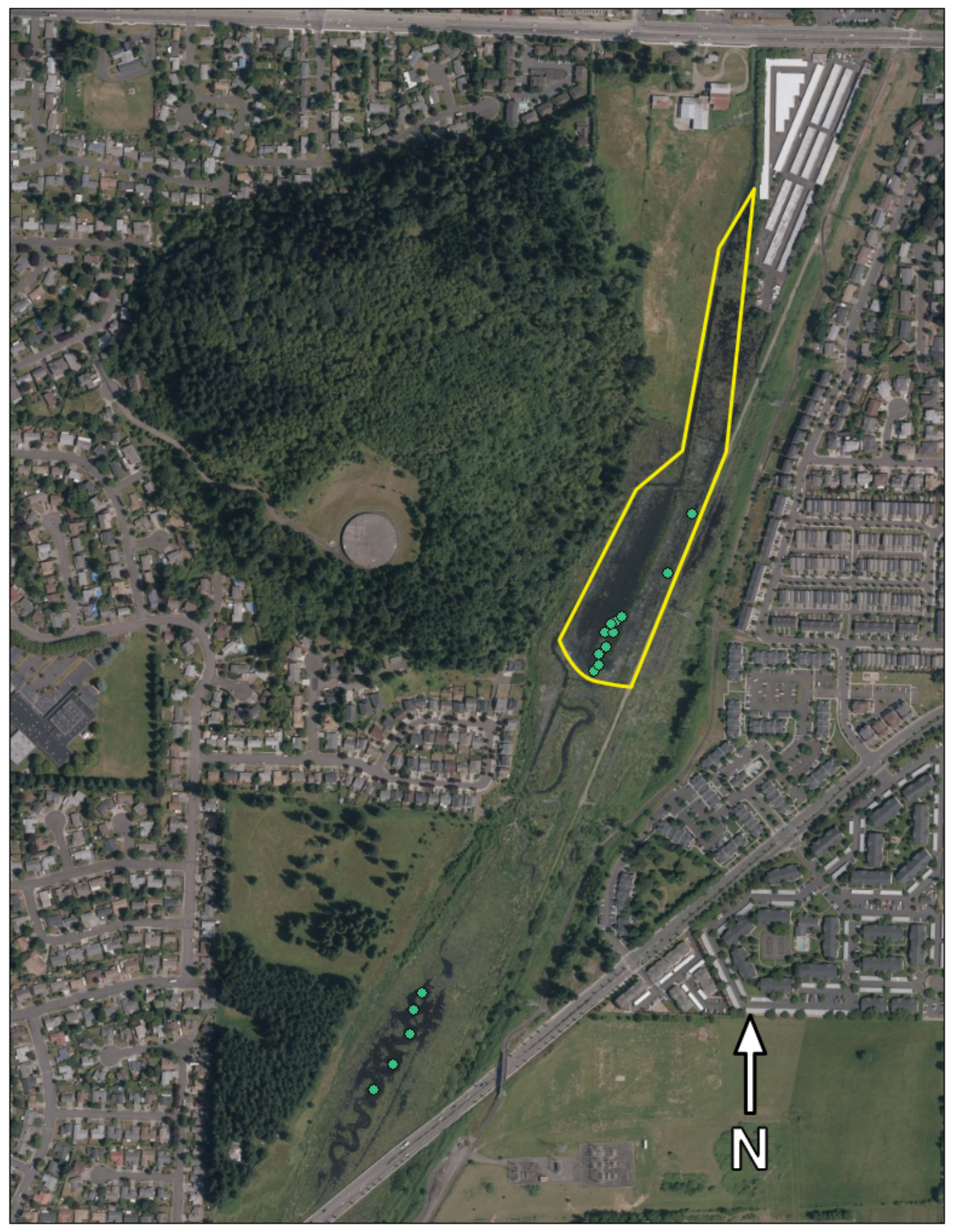

Figure 2.2. The location of all 16 manmade turtle basking structures at the site (teal). As well as an outline of the area where turtles have been observed basking (yellow). 


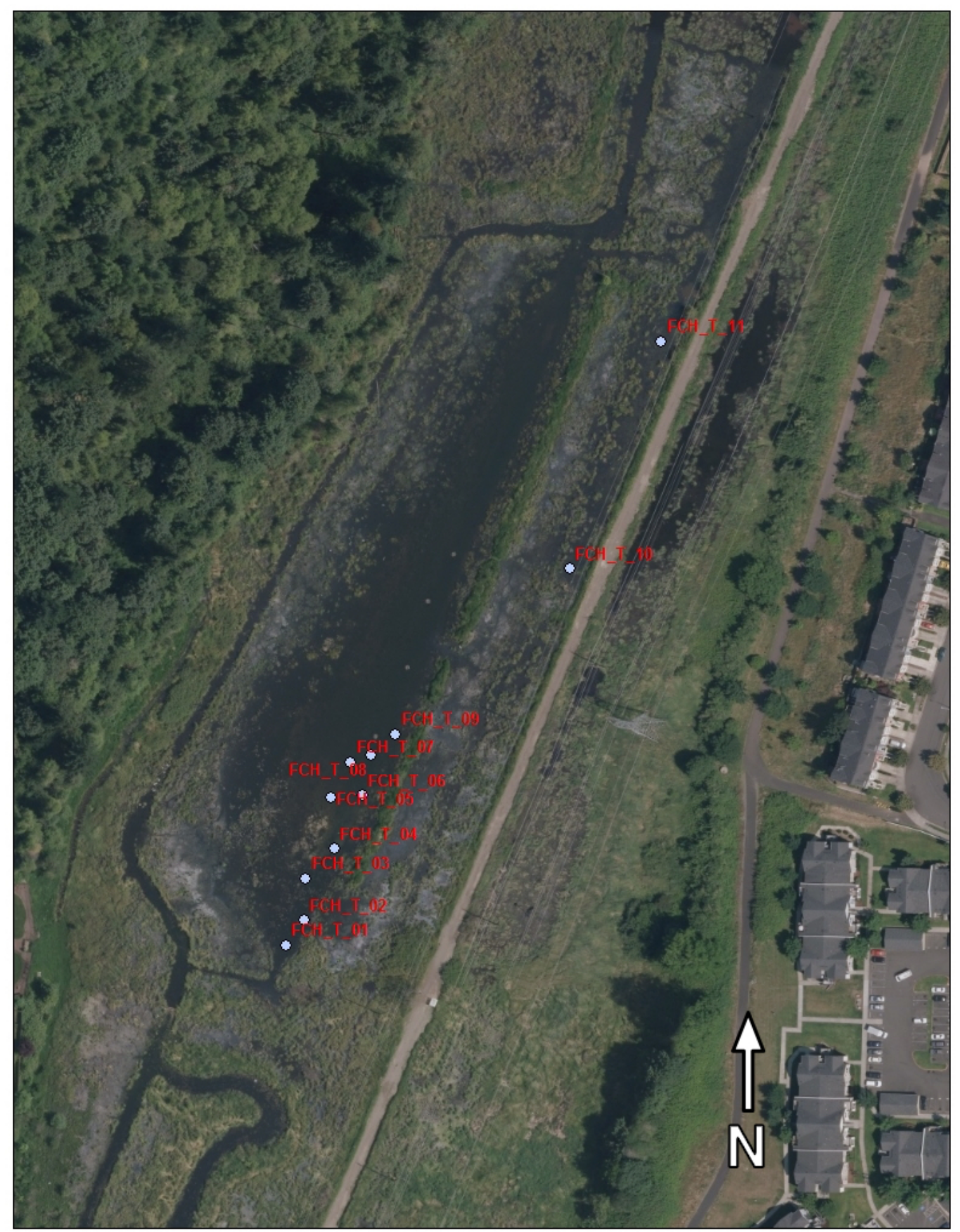

Figure 2.3. The location of all the turtle basking structures used in the northern portion of the site. Turtle were observed basking on these structures during basking surveys. This area also corresponds with the location of the GPS'd turtles. 
There are two main areas identified at FCH where turtles are nesting: the railroad bed and the southeast corner of Grant Butte on private property (Figure 2.1). The railroad bed which runs on the east side of $\mathrm{FCH}$, provides some of the best nesting habitat for the turtles. Perhaps because of its location in the middle of wetland it is protected from human encroachment, and tends to have the highest turtle occupancy both for nesting (known occurrence) and basking. The sandy soil and limited vegetation growing on the railroad bed provides the bare ground needed for nests. The southern end of the railroad bed is becoming over grown by blackberries, willows, and small vegetation. While the overgrown state in the southern end limits nesting habitat availability, it does provide protection from any human encroachment from the south.

The second area of identified nesting habitat is the southeast corner of Grant Butte and on some private property (located next to the SE corner of Grant Butte). Having the homeowner's cooperation as citizen scientists has helped greatly in studying the nesting and hatchling population at FCH. The southeast corner of Grant Butte provides one of the only southern facing slopes on the property, which is essential for proper development of eggs in nests. In 2009 city staff along with contract crews, increased nesting habitat along the southeast face of Grant Butte by clearing the area of vegetation and filling it with a mixture of native soils and gravel. Due to the presence of reed canary grass throughout the wetland, the nest area is scalped of grass every three years in order to maintain enough bare ground for nesting. When the habitat delineation (See Upland Habitat Delineation section) was done in 2014 it was noted that the vegetation needed to be scalped. Semiannual maintenance once in the fall and once in the early spring will keep the vegetation down. Creating nesting areas to support known populations is needed, but care should be taken to budget for and include maintenance of the areas, or they will become unsuitable habitat.

\section{Upland Habitat Delineation}

Purpose

To understand the current habitat status of the site, FCH was delineated for different turtle upland habitat types, especially nesting habitat. The main focus of the delineation was the North end of the site at the Gatenbein property, where future restoration projects will take place. Results from the delineations guided management recommendations, as well as the study design for the occupation study.

Methods

The upland site adjacent to the wetland was walked in the fall of 2014 looking for habitat variables (Figure 2.4) indicative of potential nesting, basking or 
upland overwintering habitat. Grant Butte was not surveyed except for the bottom edge of the butte, adjacent to the wetland. This limited surveying of the butte was accounting for the fact that turtles usually nest within 100 meters of the water's edge. East of the wetland only the railroad bed was surveyed due to limited public accessible upland and the presence of private properties. The upland was surveyed to the southern end of public property. Southwest Community Park was not surveyed as part of this study.

Habitat variables collected were based off standardized Oregon turtle habitat assessment forms created by Kutschera (2010; Figure 2.4). Methods for data collection followed those described in Bury (2001). Terrain changes were noted and slopes were found using a clinometer. At each terrain change, the aspect was recorded and the GPS location was taken at each end of the clinometer reading. At each site of bare ground, low vegetation, or other important vegetation or habitat feature (noted in Figure 2.4), the size of the area was estimated using a metric tape and then the GPS location of the area's center point was taken. Additionally, each area was characterized as current or potential nesting, overwintering or aestivation habitat. All of the habitat delineation data was entered into an ArcGIS map. The points were then used to construct the management plans for Chapter 3.

\begin{tabular}{|c|c|c|}
\hline \multicolumn{2}{|c|}{ Turtle Habitat Survey Sheet } & Name: \\
\hline Date: & Site Name/Address: & $\mathrm{AM} / \mathrm{PM}$ \\
\hline \multirow[t]{3}{*}{ Water Body } & Circle: Flowing (Creek/River/Channel/Slough, etc.) Stagnant (Pond/Lake/pool,etc.) & \multirow{6}{*}{$\begin{array}{l}\text { Notes and Comments } \\
\text { Include: Turtles seen (\#, sex, age group- } \\
\text { hatchling/juvenile/adult), behavior observed } \\
\text { (nesting, basking, terrestrial movement and } \\
\text { direction), animal sign (scat, tracks, } \\
\text { predated nests, invasive species), Human } \\
\text { use (trails, roads, trash). }\end{array}$} \\
\hline & Inlet or Outlet present $\mathrm{Y} / \mathrm{N} \quad$ Site is man-made or altered $\mathrm{Y} / \mathrm{N}$ & \\
\hline & Check one: Intermittent ___ Perennial____ Acreage_ & \\
\hline \multirow[t]{4}{*}{ Bottom Substrate } & Estimate Percent of Each: & \\
\hline & Mud __ Rocks___ Sand & \\
\hline & Other (bottom not visible, obscured by aquatic vegetation, etc.) & \\
\hline & Water Clarity (circle one): $\quad<1 \mathrm{ft} . \quad<2 \mathrm{ft} . \quad>2 \mathrm{ft}$. & \\
\hline \multirow[t]{6}{*}{ Basking Habitat } & \multirow{6}{*}{$\begin{array}{l}\text { Indicate Number of Each (approximate if many) that are at least } 6 \text { in. wide, } 1 \mathrm{ft} \text {. long, and } \\
\text { less than } 50 \% \text { decomposed. } \\
\text { Emergent logs surrounded by water } \\
\text { Emergent logs connected to shore } \\
\text { Logs on or near shore, not in water } \\
\text { Boulders, man-made surfaces, sandy/rocky shoreline present } \mathrm{Y} / \mathrm{N}\end{array}$} & \\
\hline & & \\
\hline & & \\
\hline & & \\
\hline & & \\
\hline & & \\
\hline Vegetation & \multirow[b]{2}{*}{ Floating veg. __ Emergent veg. } & \\
\hline Aquatic & & \\
\hline \multirow[t]{5}{*}{ Terrestrial } & Trees/Shrubs ( $>2 \mathrm{ft}$.) & Aquatic Vegetation Types Present \\
\hline & Distance from shore (ft.) & \\
\hline & Bare ground/moss___ Distance from shore (ft.)__ & \\
\hline & Litter layer: Distance from shore (ft.)___ Depth of litter (in.) _ & \\
\hline & & Terrestrial Vegetation Types Present \\
\hline \multirow{5}{*}{$\begin{array}{l}\text { Nesting/Juvenile } \\
\text { Habitat }\end{array}$} & \multirow{4}{*}{$\begin{array}{l}\text { Applies only if bare/mossy ground or vegetation <1ft. tall is present and has no canopy } \\
\text { Estimate area (sq. } \mathrm{ft} \text { ___ Degree of Slope__ Aspect__ } \\
\text { List any barriers to vegetation types or nesting areas (fencing, vertical slopes, etc.): }\end{array}$} & \\
\hline & & \\
\hline & & \begin{tabular}{|l|} 
Photo Documentation \\
\end{tabular} \\
\hline & & List photos and compass bearing of each. \\
\hline & $\%$ shoreline water $<2 \mathrm{ft}$. deep___ $\%$ with aquatic vegetation & \\
\hline \multirow[t]{3}{*}{ Other } & \multirow{3}{*}{$\begin{array}{l}\text { Riparian Zone: (shortest distance from shore to a disturbance): __ } \\
\text { Connected by water to other habitat? } \mathrm{Y} / \mathrm{N} \\
\text { If } \mathrm{N} \text {, distance to nearest aquatic habitat outside site boundary (if applicable) _ }\end{array}$} & \\
\hline & & \\
\hline & & \\
\hline
\end{tabular}


Figure 2.4. Habitat survey sheet used throughout the region by turtle biologists. Created by Kutschera (2010) in order to standardize habitat data collected in the region.

Results

Thirty-five points of interest were found on the Gantenbein property, ranging from manmade structures on the site to prominent areas of bare ground (red dots in Figure 2.5). The points were categorized into general types and areas.

An eastern facing slope was found on the west end of the property north of the butte (1; Figure 2.5). On the north end of the wetland, between the old location of the house and the channelized wetland, there is a small south facing slope (2; Figure 2.5). This is a small rocky patch that could provide southern facing nesting habitat.

The site has limited southern facing slopes. The southeast end of the butte is the largest area of southern facing habitat available to turtles. Having south facing slopes is important for nesting (ODFW 2015). There are several areas with cleared understory and south to eastern slopes of the butte next to the Gantenbein property which could provide nesting habitat (3; Figure 2.5).

The location of the butte next to the wetland provides upland habitat for turtles. This upland habitat could be used for nesting, overwintering and basking. The butte is a mixed hardwood and conifer forest. Tree and shrub species found on the butte include: big leaf maple (Acer macrophyllum), vine maple (Acer circinatum), Douglas fir (Pseudotsuga menziesii), birch (Betula spp), alder (Alnus rubra), hazelnut (Corylus cornuta), cottonwood (Populus trichocarpa). Parts of the butte have a thick understory of spirea (Spirea douglassi), dogwood (Cornus spp), willow (Salix spp), blackberry (Rubus armeniacus), snowberry (Symphoricarpos albus), hawthorn (Crataegus spp).

The railroad provides approximately 0.5 acres of nest habitat (Figure 2.1). This area has bare ground, sandy and rocky soil and it is protected with shrubs and blackberries on both sides of the railroad. Additionally, wetland is found on either side of the railroad. The width of the railroad bed averages $4.3 \mathrm{~m}$. The southern end of the railroad bed is overgrown with blackberries and other shrubs. The percent of bare ground decreases but could be maintained with minimal effort.

The area east of the southern wetland has many hummocks (4; Figure 2.5). The vegetation in the southern end of FCH appears to become much denser, with thick reed canary grass patches bordering the open water. These patches tend to have numerous hummocks of reed canary grass mixed in with standing water. 


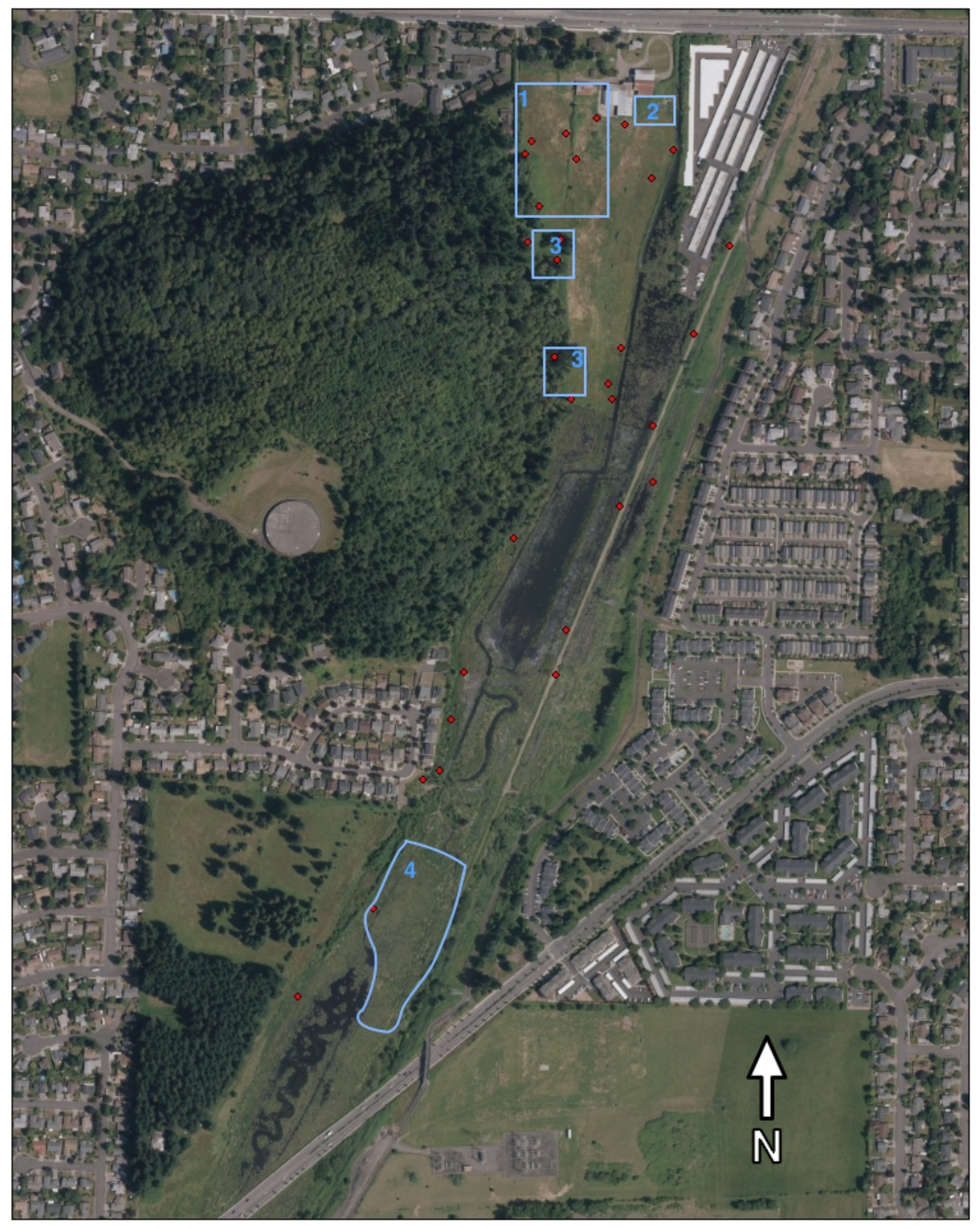

Figure 2.5. Each red mark represents an area of interest found in the habitat delineation. Points of interest could be a slope, bare ground, vegetation change, access to wetland (etc.). Each number indicates a general area of interest at the site. 1. Eastern slope; 2. Southern sloped area; 3. Open area, southern slope; 4. Southern end of wetland with reed canary grass and increased hummocks. 
Habitat Study: Habitat differences between the North and South

Purpose and methods

A GPS tracking study done in the summer of 2014 by city staff revealed that the turtles might not be using the southern end of the site (approximately 20 acres). The southern end of the site is the same area where two ditches were restored to meandering channels in 1993. The GPS study tracked five gravid adult female turtles for four months (May through August) during the nesting season. The purpose of the GPS study was to find any new nesting locations at the site. Results are summarized in Figure 2.6. During seven years of basking surveys no turtles were observed using basking structures in the southern end of the site. Due to the lack of evidence of turtles in the southern portion of the site through basking surveys, lack of catching them in traps in the southern wetland, and GPS data, the habitat study was developed to determine habitat characteristics differences between the north where the turtles have been found and the south where they have not been found. Furthermore, the southern portion of the wetlands have undergone a series of restoration projects since 1993. These studies hope to address the important habitat features so any habitat restoration that is done at the Gatenbein property does not act as a detriment to the current population and is beneficial.

Two studies were done, first a primary study to finalize methods and aquatic variables, second the transect study which was built off information learned in the preliminary study for a more complete study of the aquatic and terrestrial habitat characteristics at the site.

For both the preliminary study and the habitat study the site was split by areas of turtle presence (in the north/occupied) and areas of turtle absence (in the south/unoccupied). The transect study also further categorized each transect by location (north, middle, south) to better understand slight changes in habitat gradient in the site (see transect survey methods for more details). 


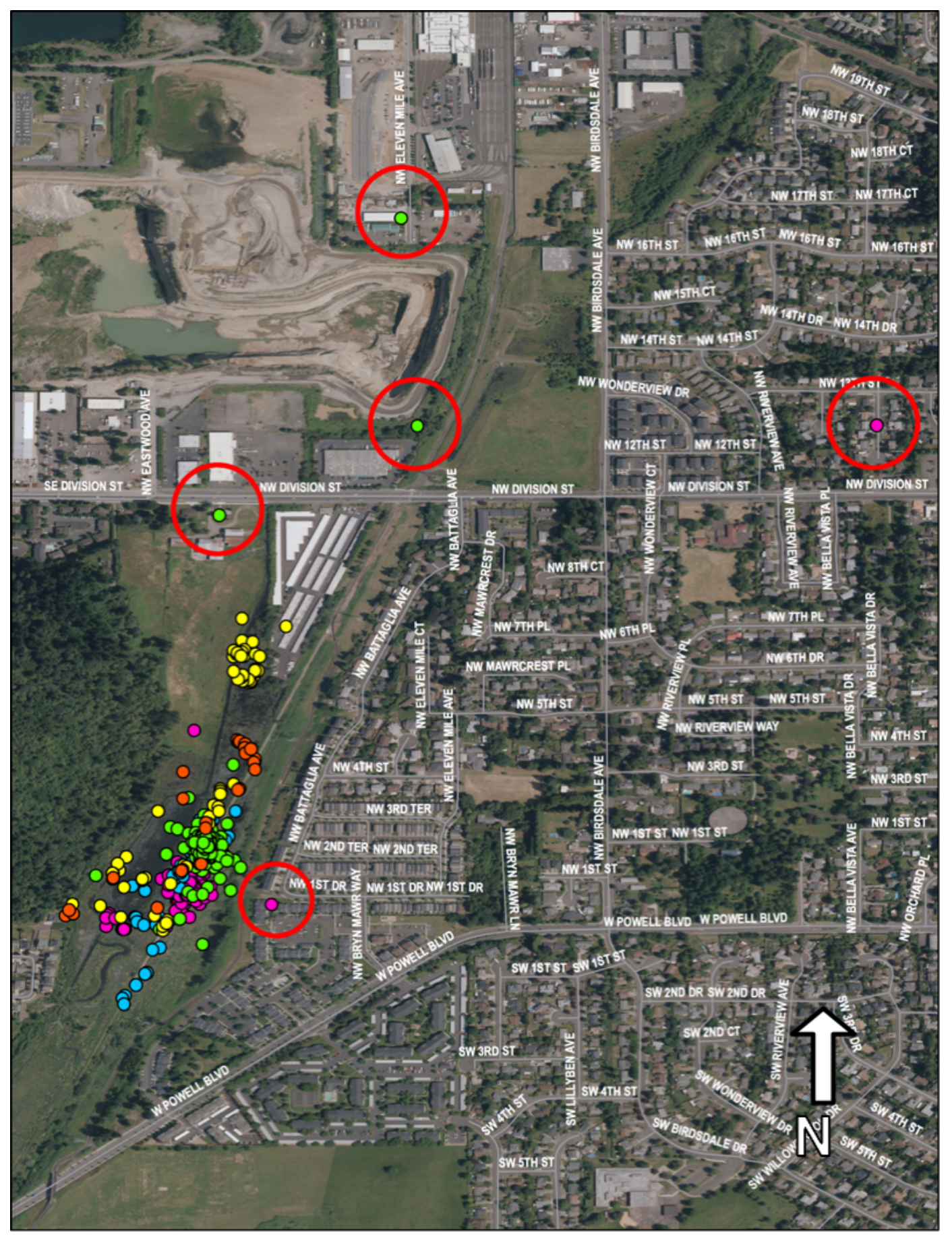

Figure 2.6. Results from GPS tracking of five female turtles in the spring and summer of 2014. Each color represents a different individual turtle. The circles indicate potential data outliers, or that some female turtles are leaving the FCH site and traveling to adjacent neighborhoods across major roads in search of aestivation and or nesting habitats. The blue turtle was the only turtle to go south of the butte. It appears to only be using terrestrial habitat, the railroad bed, where it could have been basking or looking for a place to nest. None of the turtles occupied the open braided wetland in the south. 


\section{Preliminary Aquatic Study Methods}

The preliminary study done in spring 2015 compared six aquatic variables between the North (occupied) and South (unoccupied) end of the site. The six variables collected were: $\mathrm{pH}$, conductivity, dissolved oxygen, water temperature, percent organic in substrate, and substrate depth. This study was done as a preliminary study to the transect study to determine valuable variables and clarify methods before the transect. A comparison of the preliminary results and transect results was used to ensure capture of any potential seasonality in sampling.

Twelve plots were distributed throughout Fairview Creek Headwaters. At each plot all six variables were collected. Five plots were picked in the north end of the site (occupied) and seven plot locations were picked in the south end of the site (unoccupied; Figure 2.7). Originally designed to have equal number of plots in the north and the south, two additional plots were added in the south to capture areas of the wetlands with more hummocks of reed canary grass. At each location the latitude and longitude was recorded as well as any notable habitat features (e.g. vegetation changes, substrate color or texture). Notable habitat features collected were based on literature findings (Bury 2001; Failey et al. 2007; Marchand and Litvaitis 2004b) as well as the habitat survey datasheet developed by Kutschera (2010).

Water quality variables were collected using an Orion Star A 329 Theromo scientific multiparameter meter. The $\mathrm{pH}$, conductivity, dissolved oxygen (DO) and temperature was recorded for each of the 12 locations (Table 2.2).

Turtles are known to overwinter in the substrate of wetlands and streams. In order to understand if there are differences between the substrate that they would favor in the north, substrate depth and soil samples were taken in the north and south. A three-meter-long, one inch PVC pipe with capped ends was used to measure water depth and substrate depth to the nearest millimeter. Water depth was first found by letting the pole drop until it hit the substrate. Then the substrate depth was found by pushing the pole down in the substrate as far as possible, the depth was recorded and then subtracted from the water depth to get the final substrate depth. All depths were taken by the same person to attempt to standardize the pressure applied. The area around the initial location (one square meter) was probed with the pole to ensure the recorded depth was accurate.

Substrate soil was collected with a small shovel at each of the twelve locations where the water chemistry and substrate depths were taken. Each sample was collected into a plastic bag and taken to the lab were they air dried for four days. After four days of air-drying all samples were still wet so they were oven dried at 100 degrees Celsius for 24 hours. The sample was weighed for percent difference in weight, to ensure that the sample was completely dry (less than 1 percent loss of weight). Each sample was then mixed and broken down with a mortar and pestle to homogenize samples for subsampling. The subsample was then used to find the percent organic matter using a loss on ignition procedure (Soil Survey Staff 2014). 


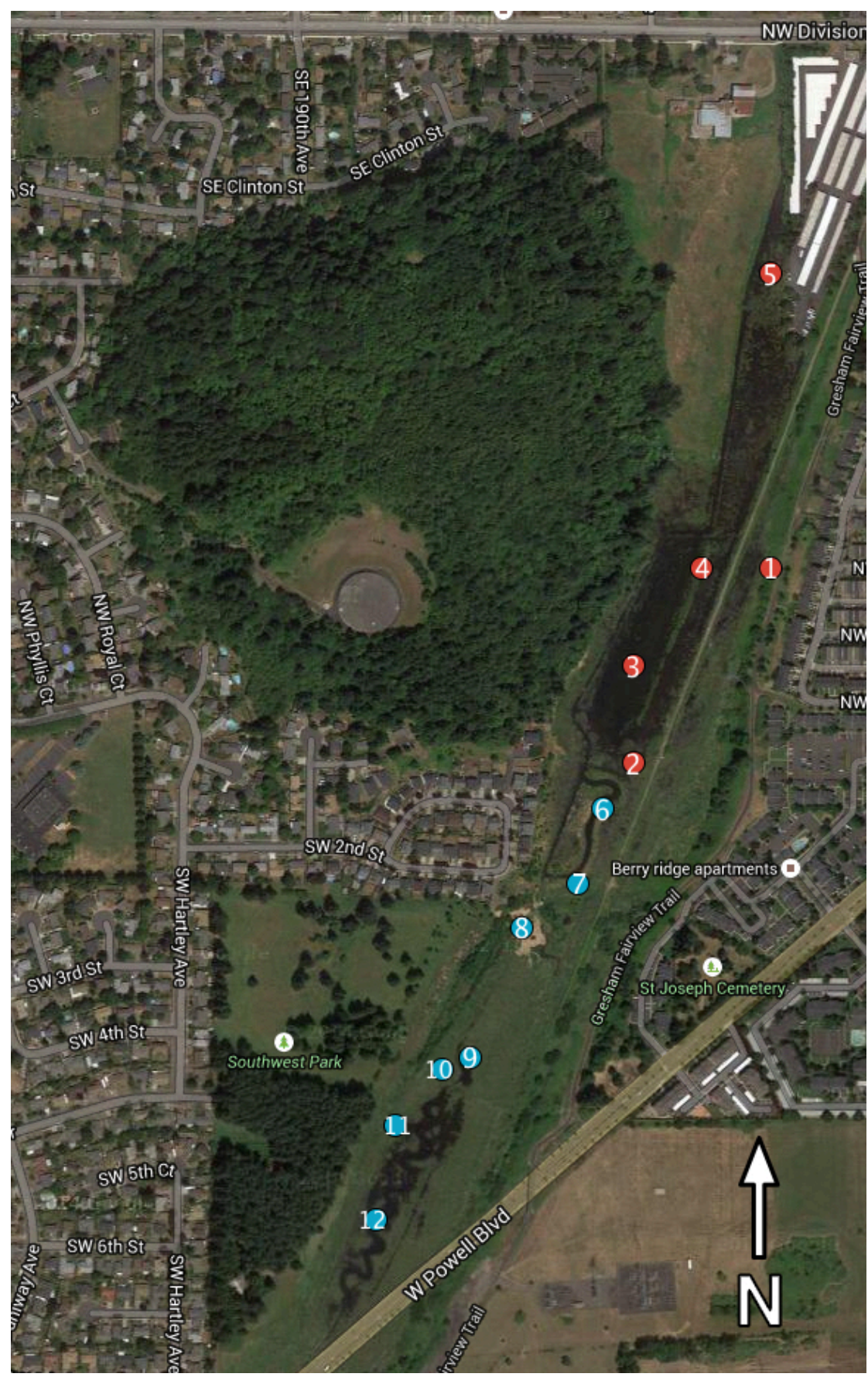

Figure 2.7. Location of all 12 preliminary study sample locations at FCH. The north samples sites (turtle presence) are in red, the south sample sites (turtle absence) are in blue. 


\section{Transect Survey Methods}

In July of 2015 the transect study was completed. This study was an expansion of the preliminary study done in the spring of 2015, adding terrestrial habitat parameters. The findings from the preliminary study were used to guide the aquatic data collection methods to be used for the transect study.

Nine randomized transects were created using ArcGIS. Each transect was categorized by turtle occupancy as well as transect location (north, middle, south). These different categories allowed for data to be analyzed at different levels to elucidate probable causes driving differences in turtle occupancy throughout the site. The site was first split into three sections (north, middle and south). This split allowed observations of changes in the habitat from north to south to be detected at the transect level. Furthermore, findings from the preliminary study suggested that habitat differences in the middle of the wetland (transects 4-6) might be creating a barrier to turtle movement between the northern wetland and the southern wetland. To randomize the locations of the transects in each of the three sections, one north to south line was drawn on the west end of the wetland for each section (north, middle and south). Three random points were generated along each line. Lines were drawn across the wetland (from west side upland through wetland to east side upland) and the east point of each transect was established (Figure 2.8).

After the nine transects were made in ArcGIS, they were then each found in the field. Transects where walked either from east to west or west to east with $1 \mathrm{~m}^{2}$ plots placed every 10 meters to get a minimum of 15 plots from every transect (Figure 2.9). Transect one plots were taken every 10 or 15 meters because the transect was much longer. One sample plot was taken at each end of the transect as well as any points along the transect of habitat change (e.g. edge of wetland, edge of shrubs, etc.) even if these didn't fall at 10 meters. The distance along the tape was taken at each point. A Trimble XT with the loaded transects was used to ensure accurate navigation of the transect lines.

Data was collected for both terrestrial and aquatic habitats along the transect. Each plot was either designated as aquatic habitat or terrestrial habitat, and then data was collected as such. The variables measured for aquatic and terrestrial habitat studies are shown in Table 2.2. This split (terrestrial or aquatic) was used throughout the study. The different parameters measured in each (aquatic and terrestrial) lead to separate analysis performed for each habitat type. 


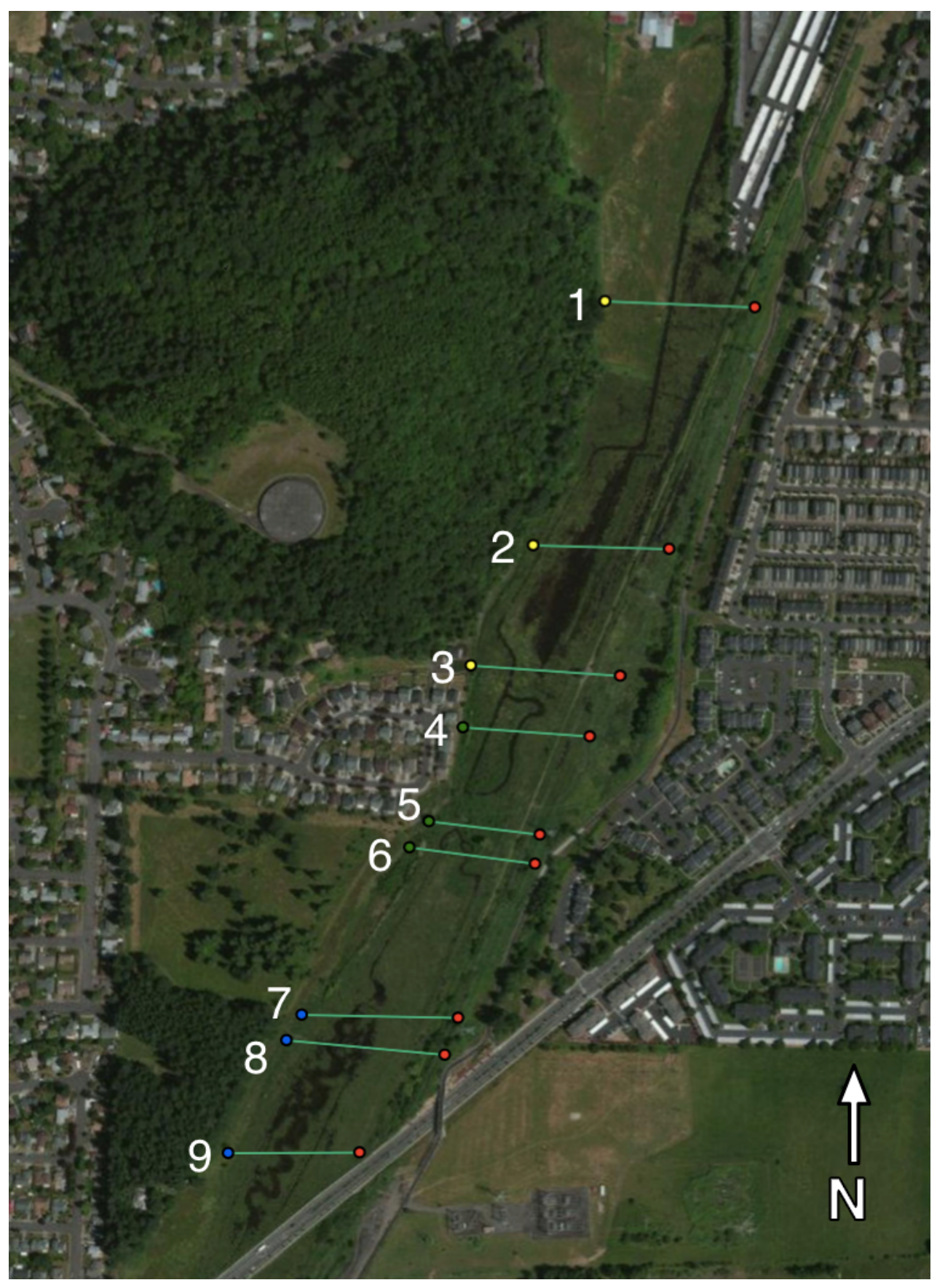

Figure 2.8. Satellite view of the location of each transect. Turtles were present along the north transects (yellow dots, transect \#1-3) and nesting along the railroad bed into transect four. The first transect runs through the Gatenbein Dairy. The middle transects 4-6 (green dots) have no record of use of aquatic habitat by turtles other than the presence of nesting turtles in the east end of transect four. Transects 7-9 (blue dots) are located in in the southern end of the wetland where turtles are absent. 


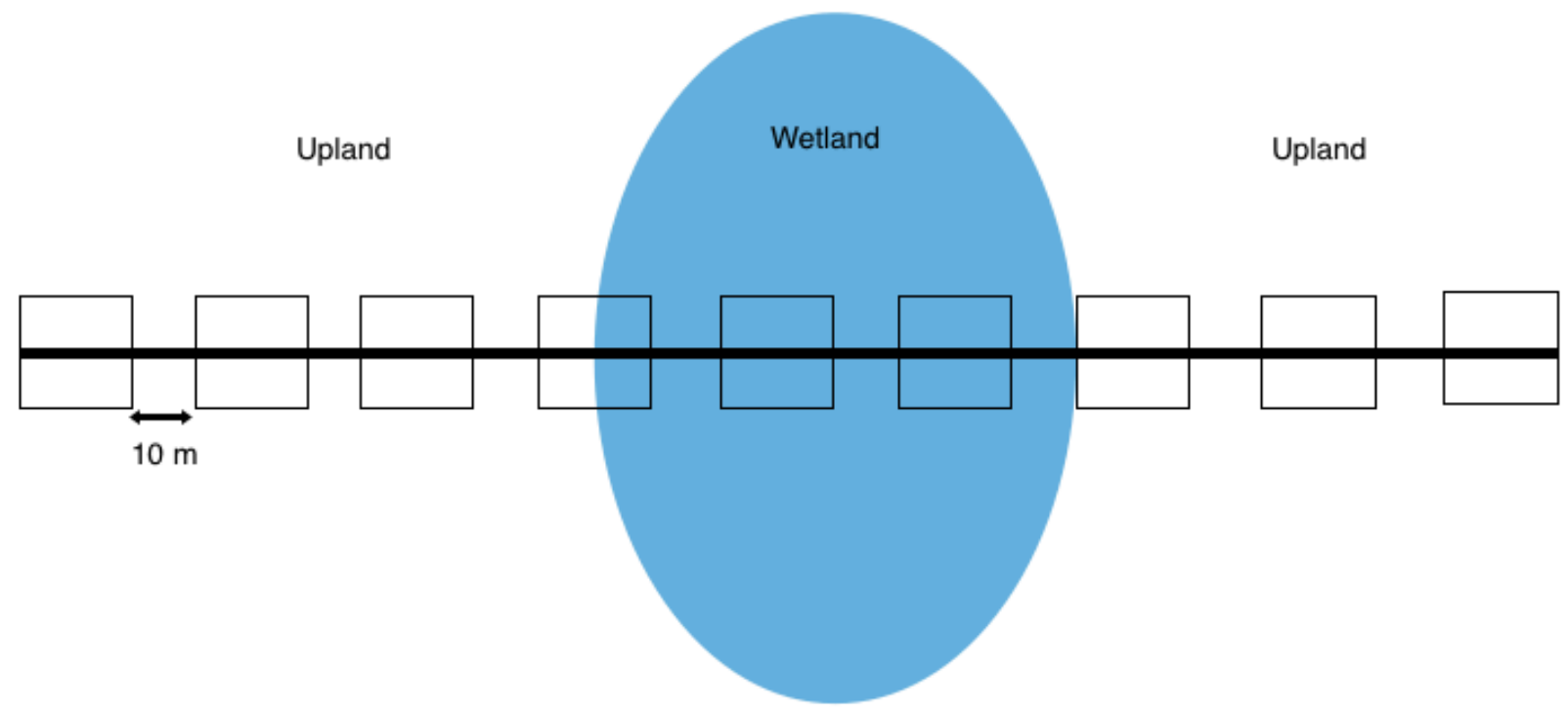

Figure 2.9. Transects were ran from west to east upland crossing over the wetland. One square meter plots (squares) were placed every 10 meters along the transect or at the edge of any major habitat transition, like the edge of the wetland. 


\begin{tabular}{|c|c|c|}
\hline Parameter & Definition & $\begin{array}{l}\text { Habitat } \\
\text { type }\end{array}$ \\
\hline $\begin{array}{l}\text { Plant Functional } \\
\text { Group }\end{array}$ & type of plant (i.e. graminoid, forb, shrub & B \\
\hline Dominant Plant & $\begin{array}{l}\text { plant species that are prominent in plot, can me more } \\
\text { than one dominant plant }\end{array}$ & B \\
\hline $\begin{array}{l}\text { Percent low } \\
\text { vegetation }\end{array}$ & the percent of the plot with vegetation $<6$ inches tall & $\mathrm{T}$ \\
\hline $\begin{array}{l}\text { Percent bare } \\
\text { ground }\end{array}$ & amount of bare mineral soil found within the plot & $\mathrm{T}$ \\
\hline Plant Density & $\begin{array}{l}\text { percentage of the plot that had plants in it, this } \\
\text { combined with bare ground to equal } 100 \%\end{array}$ & $\mathrm{~T}$ \\
\hline litter depth & $\begin{array}{l}\text { depth litter, including depth of leaves, decaying plant } \\
\text { matter }\end{array}$ & $\mathrm{T}$ \\
\hline distance to shore & how far nearest edge of plot is to the water's edge. & $\mathrm{T}$ \\
\hline DO & Dissolved Oxygen; units $=\mathrm{mg} / \mathrm{L}$ & A \\
\hline $\mathrm{pH}$ & $\mathrm{pH}$ of water in plots & A \\
\hline Percent Organic & percentage of organic matter in the substrate soil & A \\
\hline Air temp & Temperature of Air in Celsius & B \\
\hline Water temp & Temperature of Water in Celsius & A \\
\hline Water depth & $\begin{array}{l}\text { depth of water to nearest centimeter, excluding } \\
\text { substrate }\end{array}$ & A \\
\hline Substrate depth & depth of underwater substrate to nearest centimeter & A \\
\hline Open water & $\begin{array}{l}\text { percentage of the plot that has open water, not having } \\
\text { plants coming out of the water, logs, or floating } \\
\text { vegetation. }\end{array}$ & A \\
\hline $\begin{array}{l}\text { emergent } \\
\text { vegetation }\end{array}$ & $\begin{array}{l}\text { vegetation attached to substrate, includes milfoil, } \\
\text { rushes, etc. }\end{array}$ & $A$ \\
\hline floating vegetation & $\begin{array}{l}\text { vegetation that is not attached to the substrate; } \\
\text { percent of plot }\end{array}$ & A \\
\hline
\end{tabular}




\section{Transect Survey: Aquatic Methods}

Aquatic data collected in each plot included: dissolved oxygen, $\mathrm{pH}$, percent organic matter, air and water temperature, type of plant, dominant plant species, water depth, substrate depth, percentage of open water, percentage of emergent vegetation, and percentage of floating vegetation.

The water chemistry in each plot ( $\mathrm{pH}, \mathrm{DO}$, air and water temperature) were taken using an Orion Star A 329 Theromo scientic multiparameter. The water and substrate depth were taken at three points within the plot (as described in preliminary study methods) and the average was used for data analysis. One soil sample was taken for every transect and the sample plot location was recorded. Transect three had three different soil samples were taken - this was to capture differences in soil in and around a beaver channel that intersected the transect. In this case, a soil sample was collected within the beaver channel as well as next it.

Several different quantitative and qualitative parameters were collected to understand changes in vegetation communities throughout the site. Quantitative data including: percentages of the plots with emergent vegetation, floating vegetation and open water. The total percent emergent and floating vegetation per plot, could be more than 100 as they may overlap in the plot.

Qualitative plant data were collected by both the functional groups of the plants and the particular species of dominant plant in the plot. The functional group of each plant found in the plot was recorded as one of five categories: emergent, floating, shrub, forb, and graminoid. The species of dominant plants for each plot was recorded. There could be more than one dominant plant recorded. Dominant plants were determined as one of the prominent plants in the plot because of the ecological function of a plant being more important to turtles (Garden et al. 2007) than the actual plant species. Plants were not always identified beyond their genus or plant type (e.g. milfoil, algae, rush, reed canary grass).

\section{Transect survey: Terrestrial Methods}

Each plot categorized as terrestrial habitat had the following data collected: plant functional group, dominant plant, percent bare ground, plant density, percent low vegetation, litter depth, and distance to shore. Terrestrial data were collected throughout upland habitat. The distance from each plot to the water's edge was measured for each terrestrial plot. This was especially important when finding significant habitat types like bare ground to know how far hatchlings would have to move to get to the water's edge.

Seven plant functional groups were recorded: emergent, floating, shrub, forb, tree, moss, and graminiod (based on Kutschera 2010). Similar to the aquatic dominant plants data, plants were only recorded to genus or family level with several species recorded per plot. The percent bare ground and plant density were visually estimated based on percentage of the plot each occupied with the sum of both percentages equalling $100 \%$. Low vegetation was categorized as anything under $30 \mathrm{~cm}(0.3 \mathrm{~m})$ the percent per plot was visually estimated. Litter depth 
(leaves and packed down dead grass) was not found in every plot, but when litter was discovered, the average depth to the nearest centimeter and type of litter was recorded.

One of the habitat types encountered was mudflats, which was a mix of aquatic and terrestrial habitat. These areas would typically be submerged in water during the fall, winter and spring, but would dry out during the summer. In this case all the terrestrial and aquatic parameters, except water chemistry $\mathrm{pH}$, water temp, DO and conductivity) were collected. The substrate depth was taken for areas of the transect within mudflats or spaces between hummocks where water collected. Due to the nature of the data collected, mudflats were analyzed as part of the terrestrial data. Terrestrial data was also analyzed without the mudflat plots.

Data Analysis

\section{Data Analysis: Preliminary Study}

Data was analyzed for normal distribution and equal variance using statistical software R, version 3.2.0 (R Core Team 2015). T-tests were run for each of the variables testing for differences in the means. To test for equal variance between two or more samples (north and south) the Barlett's test of equal variance was run for each variable. To understand the habitat differences between the northern (turtles present) and southern (turtles absent) sites, a principal component analysis (PCA) was run using the MASS package. The number of principal components to interpret was determined through a broken stick model. The eigenvalue reported through the PCA results was compared to the estimated ones in the broken stick model (BSM). Eigenvalues greater than the estimated BSM values were deemed appropriate to use.

\section{Data Analysis: Transect Study \\ Multivariate analysis was used to look for patterns in community composition based on plant functional group $(\mathrm{N}=7)$, dominant plant type $(\mathrm{N}=30)$, and environmental data variables $(\mathrm{N}=15)$. Each plot taken in the nine transects was categorized by two habitat types: aquatic or terrestrial (upland and mudflats) based on the variables able to be collected in each habitat type. The data were then summarized by each of the nine transects, with 18 transects total analyzed, nine aquatic transects and nine terrestrial transects (Figure 2.10). Frequencies of plant types and dominant plants were found for each transect. Dominant plant species that were found in less than five of the 18 transects (transects counted twice once for aquatic and once for terrestrial) were excluded from the data analysis.}

The variables based on the three different data types (environmental, functional group and dominant plant) were visualized using Nonmetric Multidimensional Scaling (NMDS), looking for community level patterns based on presence and absence of turtles for each transect (based on previous studies; Figure 2.10). Community assemblage dissimilarities were calculated using Bray-Curtis 
distance ordination (Legendre and Legendre 2012). Multi-response Permutation Procedure (MRPP) was used to test for differences between transects with turtle presence verse absence (McCune et al. 2002) as well as transects located in the North, Middle and South. Environmental data (Table 2.2) was summarized by transect and analyzed by occupancy and habitat type.

Indicator species analysis was run on both functional groups and dominant plants using transects categorized by the turtle occupancy (Dufrêne and Legendres 1997). Indicator species analysis along with NMDS ordinations allows for understanding community based ecology and which species are indicators of identified habitat types. Indicator species analysis allows for a way to measure the association between particular species and sites. It derives indicator values for each species by within species abundance and frequency comparisons. The indicator species model is a robust model, using a Monte Carlo test to measure the significance of each species indicator value (Dufrêne and Legendres 1997).

All data were analyzed using statistical software PC-ORD (McCune and Mefford 2011) and statistical software R, version 3.2.0 (R Core Team 2015) using the Vegan package.

After trends were observed using multivariate ordinations, specific variables of interest were further analyzed. A Welch two sample t-test was performed on environmental variables that appeared to be drivers of difference based on analysis of boxplots and ordination analysis. A Benjamini-Hochberg procedure was used to control for false positives in the data (false discovery rate set to 0.25 ; Benjamini and Hochberg 1995).

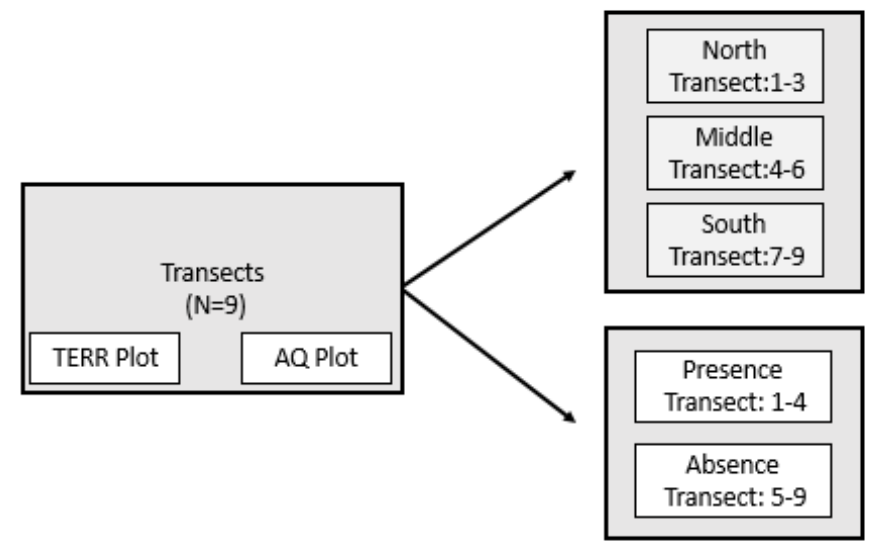

Figure 2.10. Conceptual diagram of how the plots and transects are categorized. Plots and transects are categorized by habitat type (aquatic and terrestrial). Transects are categorized by location (north, middle, and south) as well as occupancy of turtles. 
Results

\section{Results Preliminary Study}

T-tests and PCA showed differences in many variables between the northern and southern sites. Northern sites had 22.6\% higher $\mathrm{pH}$ than the southern sites $\left(\mathrm{t}_{(4.7)}=4.6, \mathrm{p}=0.01\right)$. All sites in the North had $\mathrm{pH}$ values over 7 (range: 7.28 to 9.45; Table 2.3), a basic environment. The southern sites were acidic with $\mathrm{pH}$ values between 5.87 to 6.79. Similarly, temperature was higher in the north. The mean temperature in the north was 5.01 degrees Celsius higher than the south $129.7 \%$

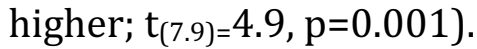

\begin{tabular}{|c|c|c|c|c|c|c|}
\hline Site & Sample & Temp(C) & $\begin{array}{l}\text { Conductivity } \\
\text { (S/cm) }\end{array}$ & $p H$ & $\begin{array}{l}\text { Substrate } \\
\text { depth }(\mathrm{mm})\end{array}$ & $\%$ Organic \\
\hline \multirow[t]{5}{*}{ North } & 1 & 20.1 & 91.28 & 8.50 & 19 & 29.57 \\
\hline & 2 & 21.6 & 181.00 & 9.45 & 6 & 29.35 \\
\hline & 3 & 21.7 & 85.00 & 8.82 & 15 & 29.85 \\
\hline & 4 & 21 & 78.50 & 7.70 & 29 & 32.41 \\
\hline & 5 & 25 & NA & 7.28 & 3 & 14.43 \\
\hline \multirow[t]{7}{*}{ South } & 6 & 16.9 & 133.20 & 6.42 & 43 & 17.80 \\
\hline & 7 & 16.4 & 206.10 & 6.38 & 4 & 31.72 \\
\hline & 8 & 15.6 & 2286.00 & 6.44 & 2 & 23.35 \\
\hline & 9 & 16.9 & 137.00 & 6.63 & 7 & 22.16 \\
\hline & 10 & 14.8 & 72.00 & 5.87 & 17 & 35.99 \\
\hline & 11 & 17.7 & 22.69 & 6.71 & 22 & 39.67 \\
\hline & 12 & 19.8 & 361.00 & 6.79 & 28 & 36.78 \\
\hline
\end{tabular}

Northern sites were differentiated from southern sites by increased temperature and $\mathrm{pH}$ (Figure 2.11, Table 2.4). Conductivity $\left(\mathrm{t}_{(6.1)}=-1.14, \mathrm{p}=0.30\right)$, percent organic matter $\left(\mathrm{t}_{(9.6)}=-0.55, \mathrm{p}=0.59\right)$, and substrate depth $\left(\mathrm{t}_{(9.99)}=-0.44, \mathrm{p}=0.67\right)$ did not statistically differ between the northern and southern locations on the site (Table 2.4). Water temperature and $\mathrm{pH}$ were highly correlated as were substrate depth and the percent organic matter in the soil (Figure 2.11). 


\begin{tabular}{|c|c|c|c|c|c|c|}
\hline & Mean (north) & Mean (south) & $\mathrm{p}$ & BTEV & $\begin{array}{l}\text { SD } \\
\text { (north) }\end{array}$ & $\begin{array}{l}\text { SD } \\
\text { (south) }\end{array}$ \\
\hline Organic & 27.12 & 29.64 & 0.59 & 0.74 & 7.20 & 8.48 \\
\hline Temp & 21.88 & 16.87 & $0.001 *$ & 0.76 & 1.86 & 1.60 \\
\hline Conductivity & 108.95 & 459.71 & 0.30 & 0.001 & 48.32 & 812.55 \\
\hline $\mathrm{pH}$ & 8.35 & 6.46 & $0.01 *$ & 0.03 & 0.87 & 0.30 \\
\hline Sub depth & 14.40 & 17.57 & 0.67 & 0.48 & 10.43 & 14.80 \\
\hline
\end{tabular}
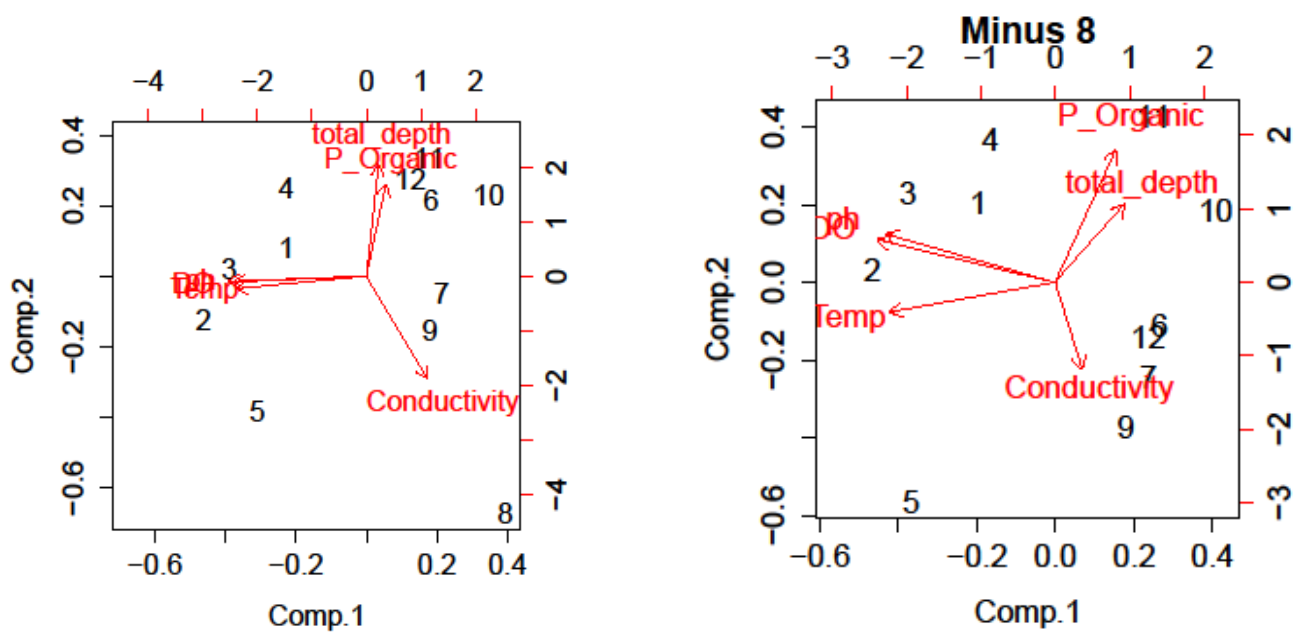

Figure 2.11. PCA biplot of all variables at Fairview Creek Headwaters. The graph on the left includes all samples. Sample eight (a southern sample) was determined to be an outlier due to its ordination on the PCA and the extremely high conductivity value. The PCA was run again omitting sample 8 (right graph). Nothern(site 1-5) and southern(sites 6-12)sites were clustered together on both graphs.

\section{Results Transect study}

The non-metric multidimensional scaling (NMDS) ordination of plant functional groups showed a difference in plant communities based on habitat type (aquatic or terrestrial) and occupancy (Figure 2.12). Differences in the aquatic and terrestrial habitat types were driven by emergent and floating vegetation in aquatic habitats and driven by moss, graminoids, forbs, shrubs and trees in the terrestrial habitats (Figure 2.12). Furthermore, there was a significant difference between the presence (TP) and absence (TA) transects for both the aquatic $(\mathrm{p}=0.021)$ and terrestrial $(\mathrm{p}=0.0405)$ plant functional groups (Figure 2.12), indicating that within habitat type there is differences between areas turtles occupy and do not occupy. 


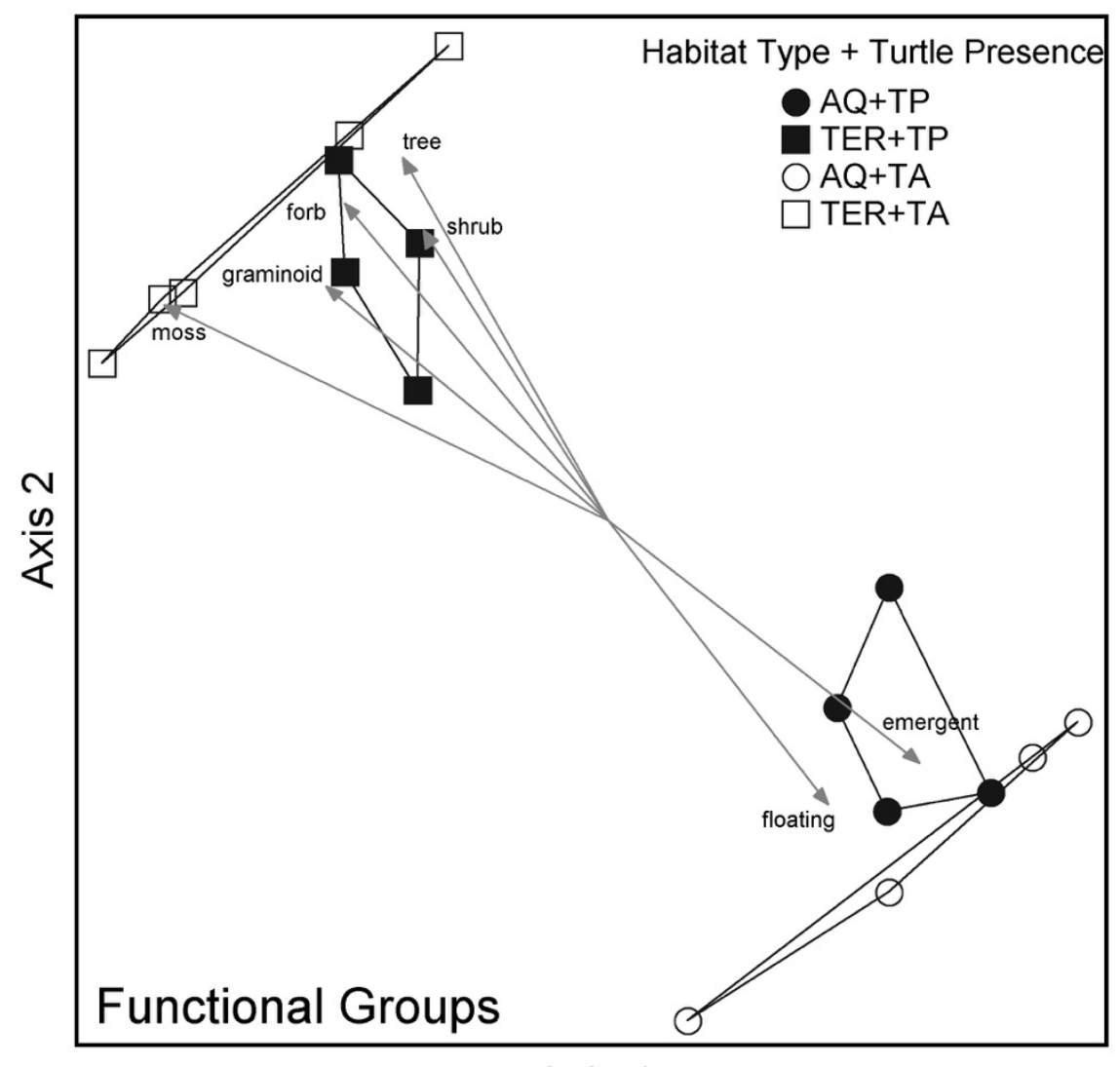

Axis 1

Figure 2.12. NMDS plot using Bray-Curtis Ordination of plant functional groups for all transects in both aquatic and terrestrial habitats. Shows a difference between habitat type and turtle occupancy. $T E R=$ terrestrial habitat, $A Q=$ aquatic habitat, $T P=$ transects with turtles present, $T A=$ transects where turtles are absent or unoccupied transects.

\section{Terrestrial habitat}

There were no significant differences between turtle occupancy for any of the plant functional group variables in the terrestrial habitat. The difference in ordination by occupancy was driven by the environmental variables, percent plant density and bare ground (Figure 2.13). Plant density was $23.9 \%$ higher in the southern transects where turtles have not been found (Table 5 and Table 10). Conversely, bare ground was found more often in northern occupied transects $\left(\mathrm{t}_{(3.67)}=-3.49, \mathrm{p}=0.03\right.$, Table 10). The other terrestrial habitat environmental variables (percent low veg, emergent veg and percent litter) were similar in occupied and unoccupied areas. 


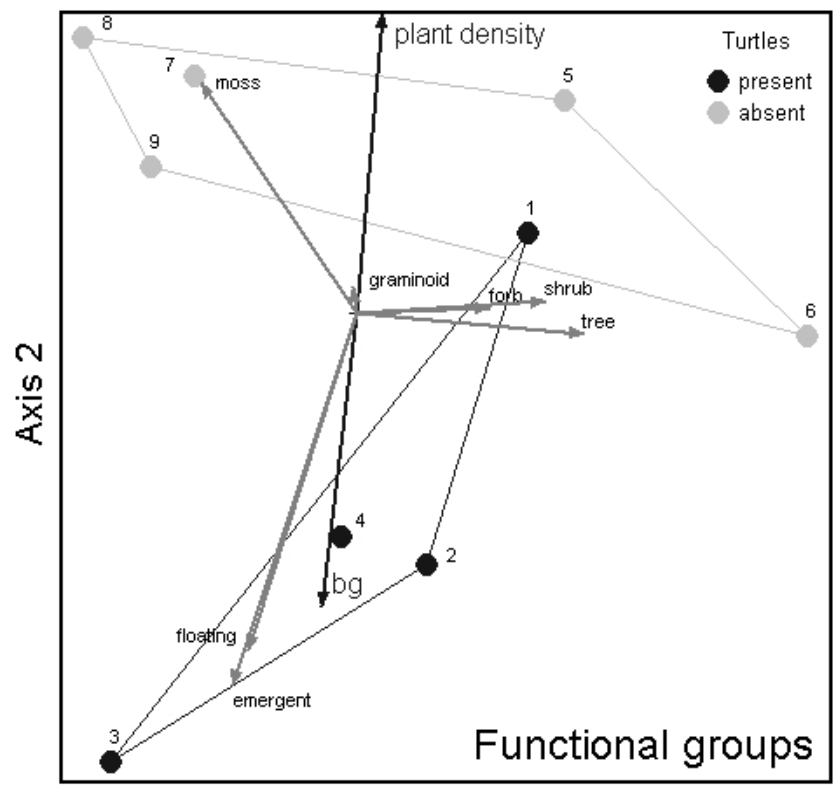

Axis 1

Figure 2.13. Terrestrial ordination for plant functional groups. Transect one is located in the northern most portion of the property where the Gantenbein dairy used to be located, its ordination closer with turtle absent transects (5-9), could be influenced by the presence of agricultural grasses in the north.

Five of the twelve dominant species were significant indicators according to the indicator species analysis. Reed canary grass (RCG; Phalaris arundinacea) and birdsfoot trefoil (BFT; Lotus corniculatus) were indicator species of unoccupied terrestrial habitat (Table 7). Reed canary grass was found in higher frequencies in transects where turtles were absent ( $p=0.038$; Table 9). Furthermore, graminoids the functional group that RCG was in, was most associated with terrestrial unoccupied habitat (Table 6). Transects 5, 7, and 8 all had graminoids found in every terrestrial plot in the transect (Table 8). Species most associated with the presence of turtles in terrestrial habitat was an unknown rush species (Juncus spp; Table 7).

All but two of the seven functional groups were found to be significant indicator species, three of which were associated with terrestrial habitat. Forbs, moss and graminoids were all found to be indicator species in the southern unoccupied end of the site. Moss had the highest indicator value (80) of all functional groups (Table 6). No functional groups were found to be indicator species in the northern section of the wetland where turtles were present. 


\begin{tabular}{|c|c|c|c|c|c|}
\hline Habitat & Variable & $\mathrm{t}$ & $d f$ & $p$ & \\
\hline Aquatic & Air Temp & 0.40 & 3.38 & 0.72 & \\
\hline \multirow[t]{9}{*}{ (transect) } & Water Temp & -1.67 & 5.82 & 0.15 & \\
\hline & $\mathrm{pH}$ & -1.01 & 3.57 & 0.15 & \\
\hline & $\%$ organic & -1.19 & 5.95 & 0.28 & \\
\hline & sub depth & -0.41 & 6.59 & 0.70 & \\
\hline & water depth & -0.38 & 6.92 & 0.71 & \\
\hline & \% emergent & -3.61 & 6.99 & 0.01 & $*$ \\
\hline & DO & -1.15 & 5.76 & 0.30 & \\
\hline & $\%$ open water & 0.66 & 6.95 & 0.53 & \\
\hline & \%floating veg & 1.19 & 6.98 & 0.27 & \\
\hline Aquatic & Air Temp & -3.60 & 26.60 & 0.001 & $*$ \\
\hline \multirow[t]{9}{*}{ (plot) } & Water Temp & -3.28 & 26.48 & 0.003 & $*$ \\
\hline & $\mathrm{pH}$ & -2.01 & 32.77 & 0.05 & $*$ \\
\hline & $\%$ organic & NA & NA & NA & \\
\hline & sub depth & -1.49 & 30.00 & 0.15 & * \\
\hline & water depth & -0.79 & 25.38 & 0.43 & \\
\hline & $\%$ emergent & -2.66 & 34.79 & 0.01 & * \\
\hline & DO & -4.24 & 27.38 & 0.0002 & $*$ \\
\hline & $\%$ open water & 0.92 & 37.00 & 0.36 & \\
\hline & \%floating veg & -0.15 & 34.57 & 0.88 & \\
\hline \multirow[t]{4}{*}{ Terrestrial } & Bare ground & -3.49 & 3.67 & 0.03 & * \\
\hline & Plant density & 3.44 & 3.38 & 0.03 & $*$ \\
\hline & low veg & -1.20 & 3.21 & 0.31 & \\
\hline & emergent veg & 0.38 & 6.66 & 0.72 & \\
\hline \multirow{4}{*}{$\begin{array}{l}\text { Terrestrial } \\
\text { (No Mudflat) }\end{array}$} & Bare ground & -2.98 & 3.85 & 0.04 & * \\
\hline & Plant density & 2.98 & 3.79 & 0.04 & * \\
\hline & litter & 0.20 & 6.87 & 0.85 & \\
\hline & low veg & -1.59 & 3.78 & 0.19 & \\
\hline
\end{tabular}




\begin{tabular}{|c|c|c|c|c|c|}
\hline Fun.Group & MaxGroup & A & B & IV & $\mathrm{P}$ \\
\hline Emergent & AP & 57 (AP) & 100 (AP) & 57.0 & $0.0048 *$ \\
\hline Floating & AA & $51(\mathrm{AA})$ & $100(\mathrm{AP})$ & 50.9 & $0.0482 *$ \\
\hline Shrub & TA & $50(\mathrm{TA})$ & 100 (TP) & 40.4 & 0.2196 \\
\hline Forb & TA & 51 (TA) & 100 (TP) & 50.8 & $0.0516^{*}$ \\
\hline Tree & TA & 59 (TA) & 40 (TA) & 23.5 & 0.5587 \\
\hline Moss & TA & 100 (TA) & 80 (TA) & 80.0 & $0.0036 *$ \\
\hline Graminoid & TA & 49 (TA) & 100 (TP) & 49.0 & $0.0086^{*}$ \\
\hline
\end{tabular}

\begin{tabular}{|c|c|c|c|c|c|}
\hline Species & MaxGroup & $A$ & B & IV & $P$ \\
\hline RCG & TA & $42(T A)$ & 100(TP) & 42.3 & $0.011 *$ \\
\hline BFT & TA & 80 (TA) & 80 (TA) & 63.7 & $0.0152 *$ \\
\hline Lemna sp. & AA & $50(A A)$ & $80(\mathrm{AA})$ & 40.3 & 0.2288 \\
\hline Algae sp & $A P$ & $60(A P)$ & $100(\mathrm{AA})$ & 59.8 & $0.0118^{*}$ \\
\hline Bulrush & $A P$ & $48(A P)$ & $50(A P)$ & 24.1 & 0.4441 \\
\hline uk_rush & TP & $65(T P)$ & 100 (TP) & 65.0 & $0.0086 *$ \\
\hline uk_forb & TP & $33(A A)$ & $75(\mathrm{AA})$ & 22.6 & 0.7105 \\
\hline uk_grass & TP & $55(T P)$ & $80(T A)$ & 40.0 & 0.2426 \\
\hline milfoil & $A P$ & $54(A P)$ & $100(A P)$ & 54.4 & $0.0302 *$ \\
\hline sedge & TA & 43 (TA) & $60(\mathrm{TA})$ & 25.9 & 0.4785 \\
\hline spirea & TA & 60 (TA) & $60(\mathrm{TA})$ & 35.7 & 0.1852 \\
\hline blackberry & TA & $53(T P)$ & $60(\mathrm{TA})$ & 28.1 & 0.2609 \\
\hline
\end{tabular}




\begin{tabular}{|c|c|c|c|c|c|c|c|}
\hline Transect & Emergent & Floating & Shrub & Forb & Tree & Moss & Graminoid \\
\hline 1-a & 1 & 0.5 & 0 & 0 & 0 & 0 & 0.33 \\
\hline $2-a$ & 0.92 & 0.67 & 0 & 0 & 0 & 0 & 0.08 \\
\hline 3-a & 1 & 0.25 & 0.25 & 0 & 0 & 0 & 0.25 \\
\hline 4-a & 1 & 0.5 & 0 & 0 & 0 & 0 & 0 \\
\hline $5-a$ & 1 & 1 & 0 & 0 & 0 & 0 & 0 \\
\hline 6-a & 0.33 & 1 & 0 & 0 & 0 & 0 & 0 \\
\hline $7-a$ & 0.67 & 0.67 & 0 & 0 & 0 & 0 & 0 \\
\hline $8-a$ & 0.6 & 0.2 & 0 & 0 & 0 & 0 & 0 \\
\hline $9-a$ & 0.8 & 0.2 & 0 & 0 & 0 & 0 & 0 \\
\hline $1-t$ & 0 & 0 & 0.27 & 0.45 & 0 & 0 & 0.91 \\
\hline $2-t$ & 0.09 & 0.09 & 0.09 & 0.36 & 0.09 & 0 & 0.82 \\
\hline $3-t$ & 0.14 & 0.21 & 0.07 & 0.14 & 0 & 0 & 0.71 \\
\hline $4-t$ & 0 & 0.14 & 0.14 & 0.29 & 0 & 0 & 0.79 \\
\hline $5-t$ & 0 & 0 & 0.27 & 0.55 & 0.09 & 0.09 & 1 \\
\hline $6-t$ & 0 & 0 & 0.57 & 0.64 & 0.07 & 0 & 0.79 \\
\hline $7-t$ & 0 & 0 & 0.1 & 0.2 & 0 & 0.2 & 1 \\
\hline $8-t$ & 0 & 0 & 0 & 0.11 & 0 & 0.22 & 1 \\
\hline $9-t$ & 0 & 0 & 0.11 & 0.11 & 0 & 0.11 & 0.89 \\
\hline
\end{tabular}




\begin{tabular}{|c|c|c|c|c|c|c|c|c|c|c|c|c|}
\hline transect & RCG & BFT & Lemna & Algae & Bulrush & Uk_rush & Uk_forb & Uk_grass & Milfoil & Sedge & Spirea & Blackberry \\
\hline 1-a & 0 & 0 & 0 & 0.33 & 0 & 0 & 0 & 0 & 0.83 & 0.17 & 0 & 0 \\
\hline $2-a$ & 0.21 & 0 & 0 & 0.57 & 0.21 & 0 & 0.07 & 0 & 0.64 & 0 & 0 & 0 \\
\hline $3-a$ & 0.5 & 0 & 0.38 & 0.25 & 0.25 & 0 & 0.125 & 0 & 0.25 & 0 & 0.125 & 0 \\
\hline $4-a$ & 0.43 & 0 & 0.71 & 0.29 & 0 & 0.14 & 0 & 0.14 & 0.29 & 0 & 0 & 0 \\
\hline $5-a$ & 1 & 0 & 1 & 0 & 0 & 0 & 0 & 0 & 0 & 0 & 0 & 0 \\
\hline $6-a$ & 0 & 0 & 1 & 0.33 & 0 & 0 & 0 & 0 & 0.33 & 0 & 0 & 0 \\
\hline $7-a$ & 0 & 0 & 0.33 & 0.33 & 0 & 0 & 0.33 & 0 & 0.67 & 0 & 0 & 0 \\
\hline $8-a$ & 0.2 & 0 & 0.2 & 0 & 0 & 0 & 0 & 0 & 0.4 & 0 & 0 & 0 \\
\hline $9-a$ & 0.2 & 0 & 0 & 0.2 & 0 & 0 & 0 & 0 & 0.6 & 0 & 0 & 0 \\
\hline $1-\mathrm{t}$ & 0.45 & 0 & 0 & 0 & 0 & 0.09 & 0 & 0.36 & 0 & 0.18 & 0 & 0.27 \\
\hline $2-t$ & 0.7 & 0 & 0 & 0 & 0.3 & 0.1 & 0.1 & 0.1 & 0 & 0 & 0 & 0.2 \\
\hline $3-t$ & 0.71 & 0.07 & 0.14 & 0.14 & 0.14 & 0.14 & 0.07 & 0 & 0 & 0.07 & 0.14 & 0 \\
\hline $4-t$ & 0.79 & 0.07 & 0.43 & 0.07 & 0 & 0.14 & 0.07 & 0.07 & 0 & 0 & 0 & 0 \\
\hline $5-t$ & 0.92 & 0.08 & 0.15 & 0 & 0 & 0 & 0 & 0.08 & 0 & 0 & 0 & 0.23 \\
\hline $6-t$ & 0.71 & 0.36 & 0 & 0 & 0.07 & 0.14 & 0 & 0.14 & 0 & 0.07 & 0.21 & 0.21 \\
\hline $7-t$ & 1 & 0.15 & 0.15 & 0.08 & 0 & 0 & 0 & 0.08 & 0 & 0.08 & 0.15 & 0.08 \\
\hline $8-t$ & 1 & 0.11 & 0.11 & 0 & 0 & 0 & 0 & 0.11 & 0.11 & 0 & 0 & 0 \\
\hline $9-t$ & 0.88 & 0 & 0 & 0 & 0 & 0 & 0.125 & 0 & 0 & 0.25 & 0.125 & 0 \\
\hline
\end{tabular}




\begin{tabular}{|c|c|c|c|c|c|c|c|c|c|}
\hline Transect & $\begin{array}{l}\% \text { bare } \\
\text { ground }\end{array}$ & $\begin{array}{l}\text { Plant } \\
\text { density }\end{array}$ & $\begin{array}{l}\% \text { Low } \\
\text { veg }\end{array}$ & $\begin{array}{l}\text { distance } \\
\text { shore }\end{array}$ & $\begin{array}{l}\text { Water } \\
\text { depth }\end{array}$ & $\begin{array}{l}\text { Substrate } \\
\text { depth }\end{array}$ & $\begin{array}{l}\text { \% open } \\
\text { Water }\end{array}$ & $\begin{array}{l}\% \text { emergent } \\
\text { veg }\end{array}$ & $\begin{array}{l}\% \\
\text { floating }\end{array}$ \\
\hline 1 & 9.09 & 90.45 & 7.18 & 28.4 & 0 & 0 & 0 & 0 & 0 \\
\hline 2 & 30 & 70 & 23.56 & 3.09 & 0 & 0 & 100 & 15 & 0.5 \\
\hline 3 & 31.83 & 68.17 & 3.96 & 9.86 & 24.75 & 33 & 0 & 3.67 & 0.33 \\
\hline 4 & 20.42 & 81.25 & 1.08 & 3.88 & 0 & 32.5 & 0 & 43 & 29 \\
\hline 5 & 0 & 99.5 & 3 & 9.44 & 44 & 10 & 60 & 40 & 60 \\
\hline 6 & 1.43 & 96.43 & 6.07 & 6.51 & 0 & 0 & 0 & 0 & 0 \\
\hline 7 & 2.5 & 97.5 & 3 & 18.89 & 0 & 0 & 0 & 0 & 1 \\
\hline 8 & 4.22 & 94.44 & 1.33 & 17.9 & 0 & 0 & 0 & 0 & 0 \\
\hline 9 & 10 & 91.875 & 0.625 & 7.675 & 0 & 34 & 0 & 70 & 0 \\
\hline
\end{tabular}

Aquatic habitat

Ten aquatic environmental variables were collected and analysed by transect as well as by plot comparing occupancy differences. Percent emergent vegetation was the only transect variable that showed significance. The mean of emergent vegetation was 53\% higher in aquatic occupied transects. Environmental data was reanalysed by aquatic plots and six variables were found to be significant. Similar to the preliminary study, water temperature $\left._{(26.48)}=-3.28, \mathrm{p}=0.003\right), \mathrm{pH}\left(\mathrm{t}_{(32.77)}=-2.01, \mathrm{p}=0.05\right)$ and dissolved oxygen $\left(\mathrm{t}_{(27.38)}=-4.24, \mathrm{p}=0.0002\right)$ were all higher in the northern occupied area of the site (Table 5 and Table 11). Percent emergent vegetation by plot was found to be $49 \%$ higher in the north (Table 5). Differences in substrate depth were not found to be significant in the preliminary study, but were found to be significantly deeper $\left(\operatorname{mean}_{\text {(present) }}=49.8\right.$, mean (absent) $=27.6$ ) in the north than the south according to the Benjamini-Hochberg procedure.

Aquatic plant functional groups grouped themselves based on turtle occupancy (Figure 2.12 and Figure 2.14; $\mathrm{p}=0.021$ ) driven by emergent and floating vegetation. Emergent vegetation had the highest indicator value for aquatic occupied habitat (57; Table 6). Floating vegetation was found to be an indicator species in unoccupied aquatic habitat (Table 6). Of the two primary dominant species (Lemna and algae spp) categorized in the floating plant functional group only algae spp was found to be a significant indicator species. Lemna was most associated with unoccupied aquatic habitat (but not significantly based on random chance; Table 7 and Table 9). However, when separating the transects into three locations (north, middle and south), Lemna had the highest frequency in the middle transects (4-5, mean frequency 82\%). The frequency of Lemna in the northern and southern wetlands was found to be similar $(p=0.094)$, suggesting the habitat in the middle of the wetland could be influencing turtle occupancy.

Dominant species showed no grouping of transects based on occupancy (MRPP; $\mathrm{p}=0.5283$; Figure 2.15). However, milfoil and algae were found to be significant indicator species in aquatic habitat. Algae was most associated with turtle presence. Conversely, milfoil which is an emergent vegetation is associated with turtle presence (IV=54; Table 7). 
None of the dominant species were indicator species in the south, where turtles were absent.

\section{Aquatic Plant Functional Group}

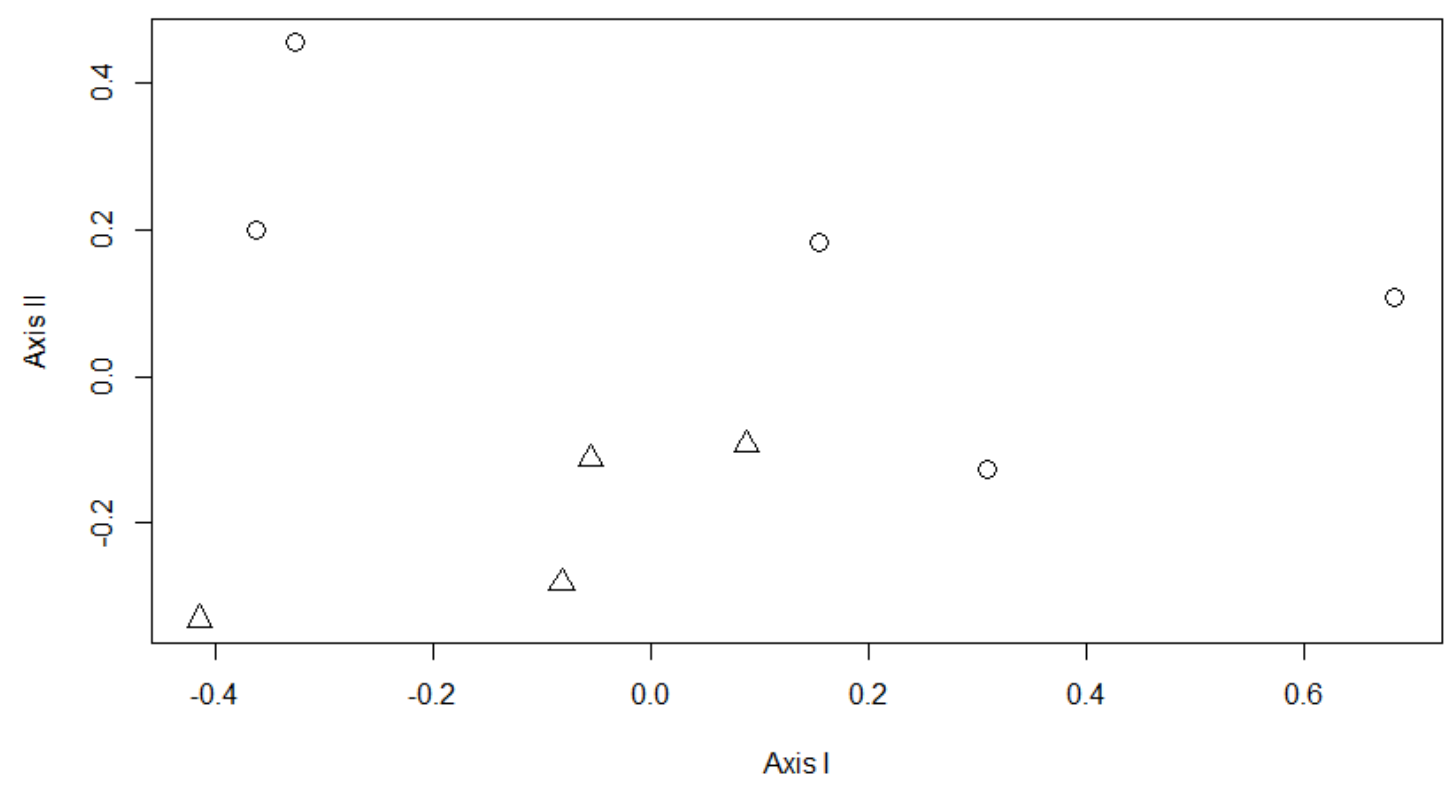

Figure 2.14. NMDS ordination of transects based on the functional groups. Triangles represent transects with turtles occupied in them. Circles represent unoccupied transects.

Aquatic Dominate Plants

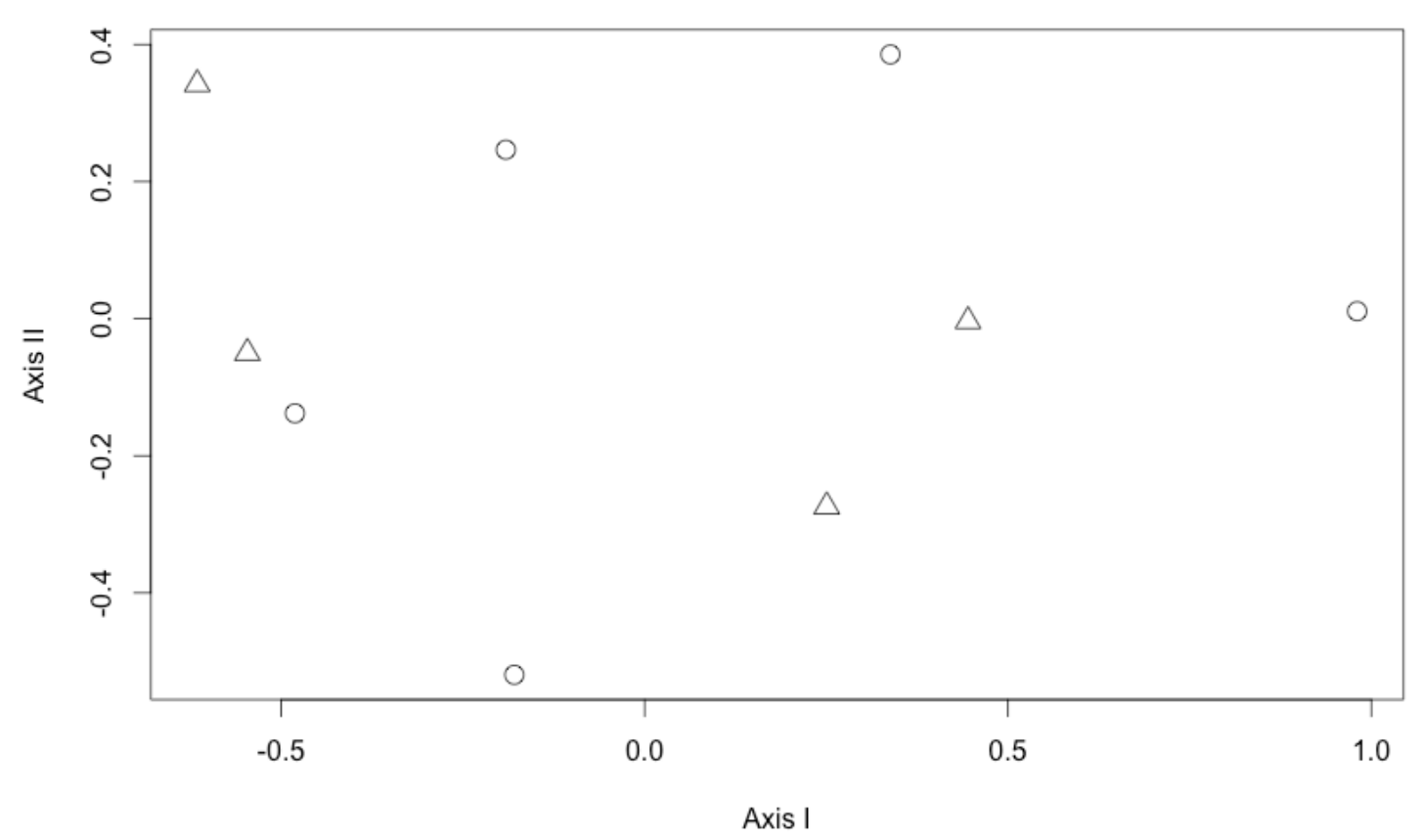

Figure 2.15. NMDS ordination of Aquatic dominant plants. Triangles represent transects where turtles were found (1-4). Circles represent unoccupied transects (5-9). 


\begin{tabular}{|llllllllllll|}
\hline \multicolumn{8}{|c|}{ Table 11. The environmental data for aquatic transects, means of each variable by transect } \\
\hline \multirow{2}{*}{ Transect } & $\begin{array}{l}\text { Air } \\
\text { Temp }\end{array}$ & $\begin{array}{l}\text { Water } \\
\text { temp }\end{array}$ & ph & do & $\begin{array}{l}\text { Water } \\
\text { depth }\end{array}$ & $\begin{array}{l}\text { substrate } \\
\text { depth }\end{array}$ & $\begin{array}{l}\% \\
\text { open } \\
\text { water }\end{array}$ & $\begin{array}{l}\% \\
\text { emergent } \\
\text { veg }\end{array}$ & $\begin{array}{l}\% \\
\text { floating } \\
\text { veg }\end{array}$ & $\begin{array}{l}\% \\
\text { organic }\end{array}$ \\
\hline \hline 1 & 26.90 & 26.88 & 6.43 & 4.55 & 71.8 & 33.2 & 68.83 & 60 & 17.58 & 69.4 \\
2 & 24.08 & 26.14 & 8.38 & 12.86 & 68.42 & 40.42 & 93.33 & 73.33 & 72.75 & 49.85 \\
3 & 24.1 & 23.75 & 7.26 & 7.615 & 53 & 88 & 81.25 & 80 & 0.75 & 31.83 \\
4 & NA & 23 & 6.935 & 5.345 & 113.5 & 36.5 & 100 & 52.5 & 3 & 86.3 \\
5 & 17.4 & 15.4 & 6.56 & 6.95 & 63 & 106 & 100 & 20 & 100 & NA \\
6 & 20.75 & 20.93 & 6.82 & 2.30 & 71 & 63.67 & 100 & 16.67 & 100 & 22.75 \\
7 & 26.4 & 25.95 & 6.915 & 9.125 & 129.5 & 9 & 63.33 & 35.67 & 58.33 & 30.1 \\
8 & 19 & 20.76 & 6.548 & 2.3 & 48.8 & 7.6 & 99 & 26 & 16 & 24.1 \\
9 & 23.16 & 24.5 & 7.232 & 4.018 & 30.4 & 14 & 100 & 58.2 & 1 & 77.05 \\
\hline
\end{tabular}

Discussion

Terrestrial Habitat

In terrestrial habitat turtles avoided areas with reed canary grass and thicker plant density. Reed canary grass, a non-native species, is known for altering wetland hydrology and plant community composition (Lavergne and Molofsky 2004; Miller and Zedler 2003; Schooler et al. 2006). Plant density was thickest in the southern part of the wetland where reed canary grass was most frequent. Marchand and Litvaitis (2004b) observed a negative relationship between turtle abundance and herbaceous vegetation, suggesting that movement of turtles may be restricted by dense vegetation. Higher plant density also restricts the availability of bare ground used for nesting. With denser vegetation it is difficult for both adult and hatchling turtles to quickly move from areas of nesting to the safety of aquatic habitat, leaving them vulnerable to predation (Christiansen and Gallaway 1984). Additionally, turtles need areas of low canopy cover for basking (Boyer 1965). Higher plant density, especially from shrubs and trees, increases shade and therefore reduces adequate basking habitat. While the tree and shrubs were not found to be indicator species and related to turtle occupancy, they could still impact basking. The lack of significance between trees and shrub presence and turtle occupancy is not surprising as there were few plots with these functional groups present.

Turtles need areas of bare ground for nesting (ODFW 2015). Terrestrial habitat around the northern wetland had a higher percent of bare ground, which is beneficial to turtles. The lack of bare ground in the south may explain why turtles have not been found in the south. Sparsely vegetated nesting habitat that is close to the edge of the wetland, therefore easily accessable, is beneficial to both adults and hatchlings. If turtles can get to and from the nesting habitat quickly, there is less of a risk of mortality through predation. Furthermore, if turtles have to cross a road or be in close proximity to a road, their risk of mortality increases.

Garden et al. (2007) found that the habitat structure was more important than the composition of specific species of vegetation for the local level management of turtles. 
Furthermore, Failey et al. (2007) found that the characteristics of the surrounding landscapes (such as percent of un-forested land and land usage), in urban areas may influence turtle species abundance more than specific pond types. The middle of FCH site, between the north and south wetland, had more terrestrial habitat per transect (mean

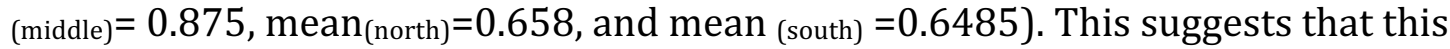
terrestrial habitat influences turtle site selection. Similarly, the lack of aquatic habitat or narrow and channelized water courses in the middle may deter turtles from moving into the southern end of the site.

\section{Aquatic Habitat}

The presence of turtles is significantly correlated to the presence of emergent vegetation. The turtles inhabit the northern end of the site where emergent vegetation is thicker, and milfoil and algae are indicator species. In fact, the turtles were observed basking near transect one in aquatic habitat, with emergent vegetation, deep water, and basic $\mathrm{pH}$ (high of 10.06). The presence of turtles basking in this area, may not be tied to the $\mathrm{pH}$ level but instead to the amount of the emergent vegetation present (Meseth and Sexton 1963). Thicker emergent vegetation such as milfoil, has many benefits to turtles including protection from predators and presence of a food source. Turtles eat vegetation as well as aquatic invertebrates that are found in areas of thick milfoil (Raney and Lachner 1942; Knight and Gibbons 1968; Nedeau et al. 2003). The deep water serves a similar role as the thick vegetation in predator avoidance. In this study water depth did not appear to differ between the transects with occupancy versus transects without. However, this observation along with the fact that only one transect was run through the area of the wetland with the large open water and deeper water (Figure 2.7) could lead to different findings if a more in depth study were done. Several studies on urban turtles in the Portland area have found that deeper water is important for western painted turtle habitat (Hayes et al. 2002; Rosenberg and Gervis 2012).

Vegetation can impact temperatures of a water body through shading as well as impacting the $\mathrm{pH}$, substrate composition and possibly dissolved oxygen. Hynes (1960) found less aquatic invertebrates in water bodies with lower DO levels. The aquatic invertebrates are an important food source for turtles. The northern area where turtles were found had thick aquatic vegetation providing suitable habitat for invertebrates. A future studying comparing vegetation and aquatic invertebrate richness and diversity at each site will strengthen the understanding of how site differences impact turtle site selection. 


\section{Chapter 3: Population}

\section{Objective and Purpose}

Mark-recapture data from 2008 to 2014 was used to estimate population abundance, summarize the capture history and create a population growth model. Findings shed light on how to best manage the population. Understanding if the population growth rate is declining or what the stage class structure of the population is will help guide management approaches to take at Fairview Creek Headwaters.

\section{Background}

An understanding of the threats to a population are essential to managing a population. Many managers focus on habitat restoration that can improve the habitat for particular species. While this is important and is needed, management is most effective when combining habitat restoration with an understanding of the population demographics.

The greatest threats to turtle populations in urban areas are: predation, roads, and reduced buffer zones (upland habitat availability). These threats lead to populations with reduced growth rates, skewed age class and sex ratios, and overall declining populations. In urban areas, population size tends to be small and isolated from others (often population sinks). Suitable habitat is often dissected by roads which threaten turtle survivorship. Proximity of roads is one of the greatest threats to females searching for nesting locations (Rosenberg and Gervis 2012). Sex ratios of urban populations are often skewed to favor males because females are often killed while searching for suitable habitat near roads (Steen and Gibbs 2004; Marchand and Litvaitis 2004b). If a site has limited nesting habitat available, females will travel farther, often across roads in search of a place to nest (Baldwin et al. 2004) thus impacting adult survival rate of the population. Furthermore, predators are more likely at the edges of habitat (such as along paths, backyards and along roads).

In order for populations to persist the population growth rate must be stable or increasing. The addition of individuals to a population through immigration and births helps increase the growth rate of the population. Unfortunately, in urban areas the fragmented landscape can create a landscape of habitat islands with little landscape connectivity. For low-vagility such as turtles, lack of connectivity in both aquatic and terrestrial habitats can make moving across the urban landscape and inhabiting new areas difficult. Without connectivity, the exposure to threats such as predation, removal for the pet trade, and road mortality is very high. Furthermore, sites in urban areas tend to be small, and wetlands, in particular often have limited adjacent upland habitat. The reduced upland buffer make recruitment (via nesting habitat) difficult, and many sites in urban areas are not acceptable habitat for turtles to occupy. Fairview Creek Headwaters is special in the fact that it has a large butte next to the wetland that turtles can occupy, thus providing the potential of nesting habitat in a safe area without the threat of having to cross a road. 
Understanding threats to the population and then managing them accordingly is the best way to protect current populations in urban areas (Rosenberg and Gervis 2012). As the landscape in Gresham has changed from natural areas to agriculture to densely populated neighborhoods, available wetland habitat has been reduced, which has undoubtedly reduced populations throughout the area. When finding a remnant population inhabiting an urban wetland as the turtle population at FCH has done, it is important to understand what is benefiting and threatening the population to best manage it.

\section{Mark-Recapture}

Field work/ data collection

Mark-recapture data was collected for seven years at FCH (2007-2014, not including 2009). Turtles were captured using a baited hoop net (Lagler 1943b). Trapping happened up to twice a year, once in the spring and once in the fall (primary capture events). Each trapping session consisted of two to five secondary trapping occasions. Secondary trapping events are consecutive days of trapping in a short period of time, these are usually considered to be closed population models, where there is no immigration, emigration, births or deaths.

During each collection, data recorded on each turtle included: carapace and plastron length, body mass, age, sex, unique scute patterns, number of marginal scutes, if females were gravid, injuries, and abnormalities (Mitchell 1988). Lengths were determined using a digital ruler. The age was determined through counting the growth annuli (Gibbons 1968b). Each turtle was uniquely marked along the marginal scutes with a unique number in accordance with ODFW policies (Cagle 1939). All data were recorded and analyzed using Microsoft excel and R.

Abundance estimate

The original intent of the mark-recapture study was to estimate population abundance. Program MARK was going to be used to estimate abundances and stage class survival rates using a robust model (Kendall et al. 1995; Pollock 1982). Unfortunately, due to the lack of recaptured turtles over several years (high number of zeros in the data) there were too many errors and the model was not able to give reliable outputs. Furthermore, any results from the model would carry a high level of uncertainty, because of unequal catching effort, and low recapture rate or capture probability (Chao 1987). Using baited hoop nets is known to have a capture bias in size classes and sex ratio of turtles (Ream and Ream 1966). This further compounded the already know biases and errors found when using Program MARK.

Two population models were used for this study, the Lincoln-Petersen model and the Schnabel estimate. Lincoln Peterson and Schnabel estimate are valid only if: (1) animals do not lose marks; (2) marks are correctly noted; (3) population is closed, (i.e, there are no births, deaths, or emigration during the study), and (4) all individuals in the population have equal probability of capture. Lindeman (1990) recommended using the Schnabel 
method (Schnabel 1938) for estimates of abundance in turtles due to the small sample size and low recapture rate.

Mark-recapture data from the spring of 2014 was used to estimate the abundance using both the Lincoln Peterson method as well as the Schnabel method. Trapping data from May 29 to 31, 2014 were used for the estimates. The short capture history met the assumption for a closed population model.

\section{Lincoln Petersen Mark-Recapture Estimate}

Lincoln- Petersen (LP) estimates are used to estimate population abundance in a close population. In order to not violate the closed population assumption, mark-recapture data from two days of capture ( $30^{\text {th }}$ and $31^{\text {st }}$ of May) were used for the Lincoln - Petersen estimate. A total of 56 turtles were captured between the two days. The fourteen turtles that were captured in the first sample (M) all were released, allowing for equal probability of capture on day two. There were 47 turtles captured in the second sampling event (C). A total of five of the turtles were recaptured (R) during the second sampling.

$$
\begin{aligned}
& M=14 \\
& C=47 \\
& R=5
\end{aligned}
$$

Population size was estimated using the equation: $\left(\frac{(M+1) *(C+1)}{R+1}\right)-1$

Results:

Estimated population size $\left(\mathrm{N}_{\text {est }}\right): 119$

Upper 95\% confidence interval: 193.3

Lower 95\% confidence interval: 44.73

Standard error of N: 37.12

\section{Schnabel Estimate}

The Schnabel estimate accounts for all the sample days (secondary events) in a short time frame. A population abundance estimate was found using the Schnabel estimate equation ( $\left(\mathrm{SN}_{\mathrm{est}}\right)$. Where $\mathrm{C}_{\mathrm{t}}$ is the number caught in each sample, $\mathrm{M}_{\mathrm{t}}$ is the number of marked animals at large, and $\mathrm{R}_{\mathrm{t}}$ is the number of recaptured turtles in each sample.

$\mathrm{SN}_{\mathrm{est}}=\frac{\Sigma(C t * M t)}{\Sigma(R t)}$

Results:

$\mathrm{N}_{\mathrm{est}}=93.57$

Variance $=8.158$ E-06

Standard error $=0.00286$ 
Upper 95\% confidence interval: 196.5

Lower $95 \%$ confidence interval: 61.4

Both the LP and Schnabel abundance estimates have large variation between the upper and lower 95\% confidence interval for the estimate. One limitation of the Schnabel estimate is there were only three sample events, hence the confidence in the estimate is low. Other errors with the estimate may come from unequal catchability, which can affect population size estimates. Low detectability, or low number of recapture events produces a larger range in confidence intervals. Koper and Brooks (1998) looked at unequal catchability in painted turtles and found large variation in capture probabilities and almost all estimates were below the actual population size.

\section{Capture History}

During the seven years of capture data, 269 individual adult and juvenile turtles were collected. One hundred (37\%) of those individuals were only captured one time and 169 (63\%) were captured multiple times over multiple years. Furthermore, 125 (46.5\%) of the individuals were only captured in one year of the study, meaning the 25 of those were captured multiple times in the same year but never seen again in another year. Just over half $(n=144 ; 53.5 \%)$ of the turtles caught were captured in two or more years. It should also be noted that $66(24.5 \%)$ of the turtles were captured just in 2014. For all seven years, females accounted for $43 \%(n=134)$ of the captures, males accounted for $39 \%(n=122)$ of the captures with juveniles and unknowns accounting for 17\% $(n=54)$.

There was a total of 12 primary capture events over the seven years. There were 777 total captured turtles (counting recaptured turtle events) during the seven years (Table 3.1). In 2007 and 2008 turtles were only captured in the fall. In 2010 and 2011 turtles were only captured in the spring. Starting in 2012 turtles were trapped both in the fall and the spring of each year.

\begin{tabular}{|c|c|c|c|c|c|c|c|c|}
\hline Year & 2007 & 2008 & 2009 & 2010 & 2011 & 2012 & 2013 & 2014 \\
\hline Primary & 1 & 1 & 0 & 1 & 2 & 2 & 3 & 2 \\
\hline Secondary & 1 & 2 & 0 & 5 & $4(2,2)$ & $7(4,3)$ & $7(3,1,3)$ & $7(3,4)$ \\
\hline Season (primary) & $\mathrm{F}$ & $\mathrm{F}$ & N/A & $\mathrm{F}$ & $s / s$ & $S / F$ & $S / S / F$ & \\
\hline
\end{tabular}

The total number of turtles captured each year was highest in 2012 and 2014 (Figure 3.1). The oldest adult turtle found was over 20 years old. Juveniles, or immature adults were found to be between 1 and 5 years old. Juveniles weighted between $7.05 \mathrm{~g}$ and $197 \mathrm{~g}$. Turtles identified as females were found to weight between 55 and $1767 \mathrm{~g}$. Males weighted between 91 and $730 \mathrm{~g}$. 


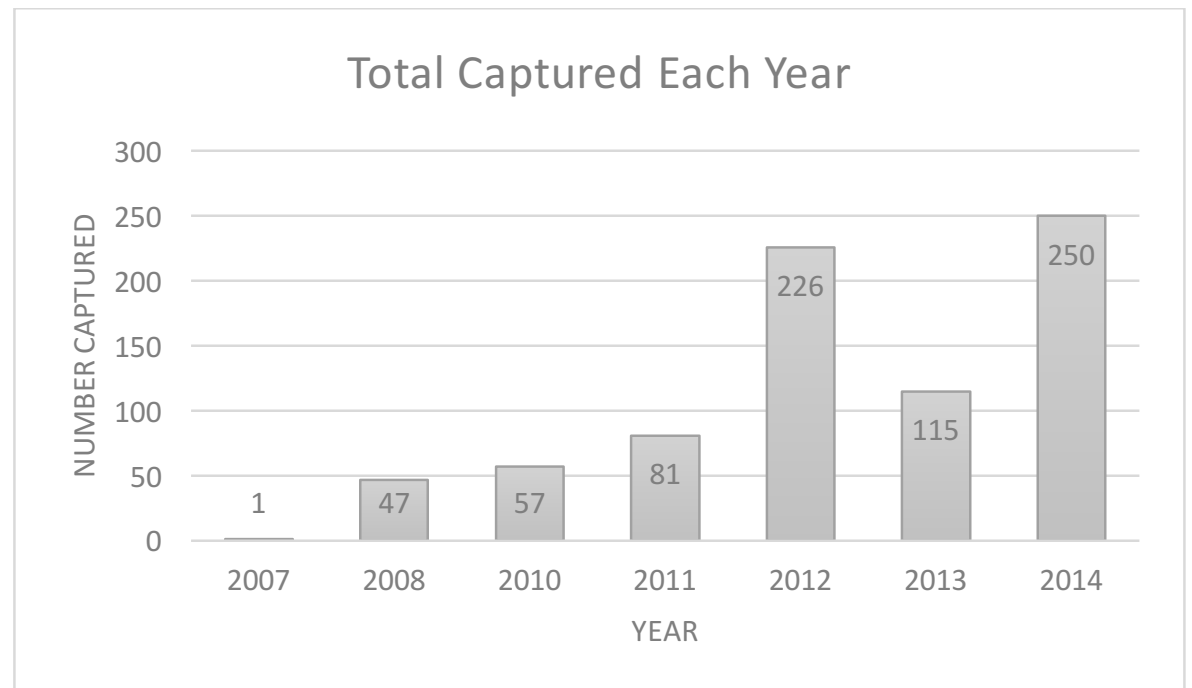

Figure 3.1. Total number of adults and juvenile turtles captured each year of the study. This number includes recaptured turtles from year to year.

Turtles were trapped in both the fall and spring for three years of the study (20122014). In 2012 and 2014 more turtles were captured in the fall than in the spring. In 2013 was the opposite with 95 turtles caught in the spring and only 20 captured in the fall. Capture effort was similar for all three years with three to four secondary capture events taking place in each season. Almost half of the individual unique turtles were captured in both seasons (Table 3.2).

\begin{tabular}{|l|l|l|}
\hline \multicolumn{3}{|l|}{ Table 3.2. Seasonality of turtles captured } \\
\hline Only spring & Only Fall & Both season \\
\hline 52 & 86 & 131 \\
\hline $19.3 \%$ & $32 \%$ & $48.7 \%$ \\
\hline
\end{tabular}

Sex ratio is often found to be skewed in urban populations. Females can be attracted to roads, which cause a male dominated population (Marchand and Litvaitis 2004b; Steen et al. 2006; Aresco 2005). Nesting habitat can be found in shaded areas which produce a higher number of male hatchlings, based on the fact that sex is determined in turtles by temperature (Gibbs and Steen 2005). Also, capture history data can be skewed based on catch effort and that baited hoop traps tend to be male biased (Ream and Ream 1966). Sex ratios in the FCH population appear to be close to 1:1, with most of the years having slightly more females (Figure 3.2; Table 3.3). The number of male and female turtles did not vary much by season. Over the entire study more female turtles $(n=210 ; 56 \%)$ were captured in the spring than male turtles ( $\mathrm{n}=152 ; 46 \%)$. Conversely, more males were captured during fall surveys $(\mathrm{n}=175 ; 54 \%)$ than females $(\mathrm{n}=167 ; 44 \%)$ with all others captured being juvenile or unknown gender (Table 3.4).

Each turtle was categorized in to a size class based on the length of the plastron (every 10 $\mathrm{mm}$ ). There were 16 size classes from 60-210, and one category for unknown length turtles (Table 3.5). More males were caught in the smaller size classes than females (size 
class $90-140 \mathrm{~mm})$. More females were caught in the larger size classes. The largest adult, a female, had plastron of $213.82 \mathrm{~mm}$ and carapace of 230.39 .

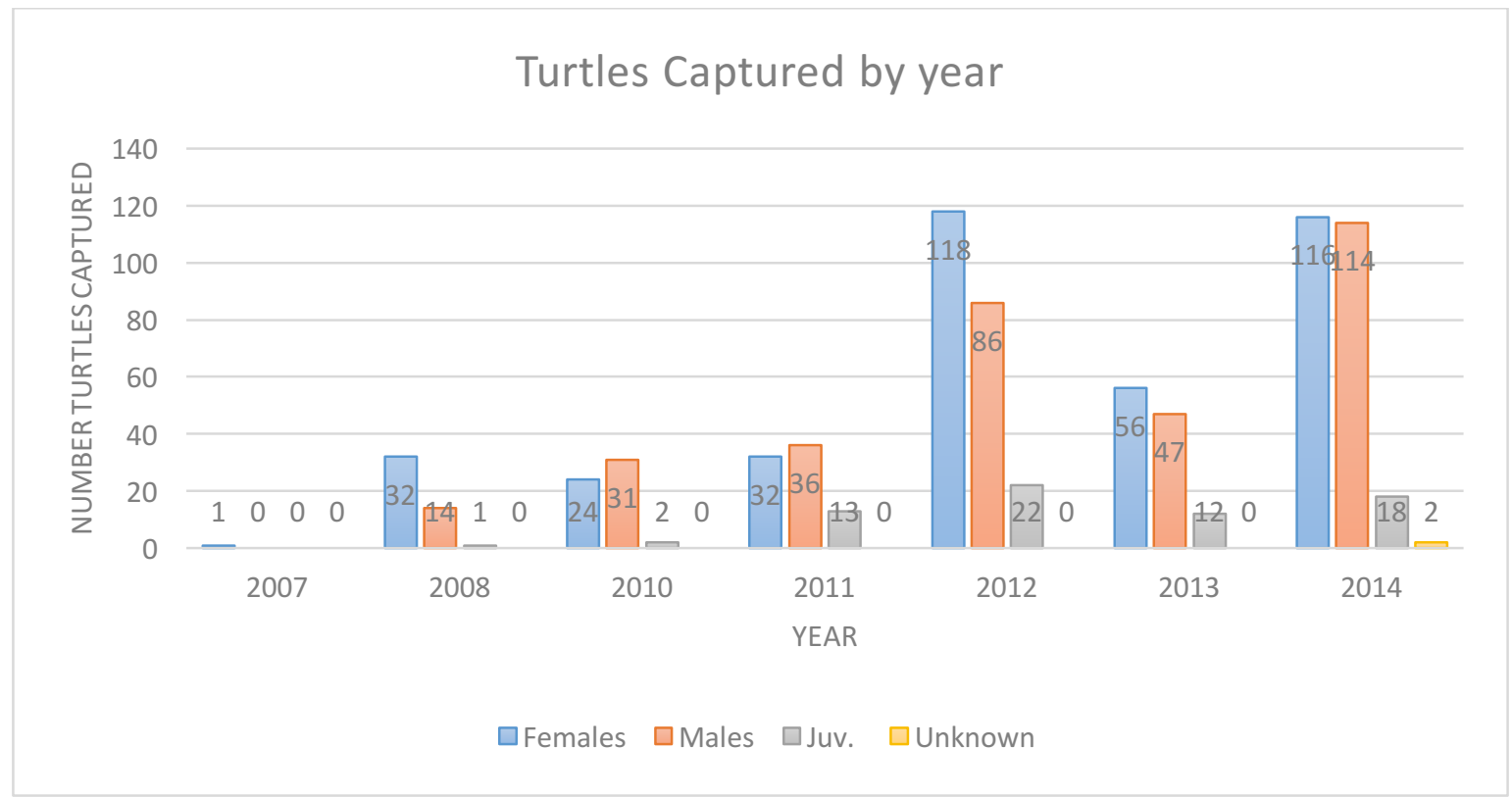

Figure 3.2. Individual turtles captured each year, the count numbers include recaptured individuals from year to year. A total of 777 turtles were captured, 68 juveniles, 328 males, 379 females, and 2 unknown gender.

\begin{tabular}{|c|c|c|c|c|c|c|c|c|}
\hline & 2007 & 2008 & 2010 & 2011 & 2012 & 2013 & 2014 & Grand Total \\
\hline \multicolumn{9}{|l|}{ Females } \\
\hline Recapture & 1 & 32 & 24 & 32 & 118 & 56 & 116 & \multirow[t]{2}{*}{377} \\
\hline Individual & 1 & 32 & 23 & 28 & 65 & 41 & 72 & \\
\hline \multicolumn{9}{|l|}{ Juvenile } \\
\hline Recapture & & 1 & 2 & 13 & 22 & 12 & 18 & \multirow[t]{2}{*}{68} \\
\hline Individual & 0 & 1 & 2 & 10 & 20 & 10 & 18 & \\
\hline \multicolumn{9}{|l|}{ Male } \\
\hline Recapture & 0 & 14 & 31 & 36 & 86 & 47 & 113 & \multirow[t]{2}{*}{327} \\
\hline Individual & 0 & 12 & 23 & 26 & 53 & 37 & 71 & \\
\hline Unknown & 0 & 0 & 0 & 0 & 0 & 0 & 2 & 2 \\
\hline \multicolumn{9}{|l|}{ Ratio (F:M) } \\
\hline Recapture & $1: 0$ & $2.28: 1$ & $1: 1.29$ & $1: 1.125$ & $1.37: 1$ & 1.19:1 & $1.03: 1$ & $1.15: 1$ \\
\hline Individual & $1: 0$ & $2.6: 1$ & $1: 1$ & $1.08: 1$ & $1.2: 1$ & 1.1:1 & $1.01: 1$ & $1.2: 1$ \\
\hline
\end{tabular}




\begin{tabular}{|llll|}
\hline \multicolumn{4}{|l|}{$\begin{array}{l}\text { Table 3.4. Number of total turtles captured each season during } \\
\text { the seven-year study. }\end{array}$} \\
\hline Sex & Fall & Spring & Total \\
\hline \hline Female & $167(44 \%)$ & $210(56 \%)$ & 377 \\
Juvenile & $22(32 \%)$ & $46(68 \%)$ & 68 \\
Male & $175(54 \%)$ & $152(46 \%)$ & 327 \\
Unknown & $5(100 \%)$ & 0 & 5 \\
Grand Total & 369 & 408 & 777 \\
\hline
\end{tabular}

\begin{tabular}{|c|c|c|c|c|c|c|c|c|}
\hline \multirow{2}{*}{ Size Class (mm) } & \multirow{2}{*}{ Ratio(F:J:M) } & \multicolumn{7}{|c|}{ Year } \\
\hline & & 2007 & 2008 & 2010 & 2011 & 2012 & 2013 & 2014 \\
\hline 60 & $0: 0: 0$ & & & 1 & & & & 2 \\
\hline 70 & $2: 0: 0$ & & 1 & & & 1 & & 4 \\
\hline 80 & $4: 3: 2$ & & 1 & & 3 & 9 & 1 & 9 \\
\hline 90 & $6: 6: 7$ & & 3 & 2 & 6 & 10 & 4 & 9 \\
\hline 100 & $15: 2: 41$ & & 5 & & 3 & 23 & 19 & 20 \\
\hline 110 & $22: 0: 64$ & & 5 & 1 & 2 & 18 & 25 & 38 \\
\hline 120 & $32: 0: 49$ & & 6 & 6 & 9 & 13 & 11 & 36 \\
\hline 130 & 23:0:32 & & 1 & 6 & 12 & 7 & 3 & 26 \\
\hline 140 & 23:0:28 & & 2 & 4 & 8 & 21 & 4 & 12 \\
\hline 150 & 23:0:16 & & 3 & 3 & 2 & 7 & 11 & 13 \\
\hline 160 & $18: 0: 10$ & & & 1 & 4 & 6 & 5 & 12 \\
\hline 170 & 16:0:12 & & 3 & 3 & 3 & 8 & 1 & 10 \\
\hline 180 & $13: 0: 0$ & & 1 & 2 & 1 & 5 & & 4 \\
\hline 190 & $52: 0: 0$ & & 8 & 8 & 5 & 18 & 4 & 9 \\
\hline 200 & $62: 0: 0$ & & 5 & 5 & 7 & 21 & 10 & 14 \\
\hline 210 & $13: 0: 0$ & 1 & 1 & & 1 & 5 & 1 & 4 \\
\hline Unknown & $51: 2: 58$ & & 5 & 13 & 16 & 54 & 16 & 26 \\
\hline Grand Total & $375: 13: 319$ & 1 & 50 & 55 & 82 & 226 & 115 & 248 \\
\hline
\end{tabular}

Hatchlings found emerging from nests on a private property were analyzed separately from the adults. Data was collected on a total of 283 hatchlings during 2007-2014. Between 1 and 15 hatchlings emerged from each nest. Most of the hatchlings weighted 4-6 grams with a range of 0-6g recorded for all hatchlings. 


\section{Discussion}

This population does not follow the trend of other urban sites with the sex ratio skewed to more males in the population. Furthermore, both male and female turtles were caught in both seasons at similar rates, indicating no sex bias between seasons. One issue presented in this study is the unequal catchability. A number of the turtles were trap happy, meaning the same turtle would be in the trap with each successive trapping. Hoop nets were used to trap the turtles. The size of the netting in the traps selects for larger turtles. Thus, capturing all age classes is more difficult using these traps. This can be seen when looking at the capture history for size classes and the fact that more females (larger size class) were caught than males and no turtles under $60 \mathrm{~mm}$ were found in the traps. Conclusions drawn about the population size especially regarding hatchings and juveniles should consider the unequal catchability.

\section{Population Growth Rate Model}

\section{Purpose and Methods}

Understanding population growth rates is very important for making conservation plans for a population. A theoretical model was built in Matlab to test how changes in survivorship of the different stage classes would influence the population growth rate. Projection matrixes are commonly used to calculate growth rates in populations. Understanding growth rate is also important for conservation of species and what life stages managers should focus management. Each life stage has unique factors influencing its survivorship, these rates ultimately determine the population growth rate (Figure 3.3) Stage projection matrices are often used for organisms with discrete life stages when breaking up by ages is difficult, as it is with turtles. Furthermore, stage projection matrices allow us to conduct sensitivity and elasticity analyses which points out the vital rates (e.g. birth and death rates) that will affect the population growth rate the most. 
SH: Survivorship of hatchlings,

SJ: survivorship of juveniles,

SA: survivorship of adults,

F: fecundity,

FSA: fecundity of small adults,

FLA: fecundity of large adults,

Fx: px*F

Px: proportion that survive from one stage class to the next,

SC: Number of individuals in each stage class

GR: Growth rate $(\mathrm{Nt}+1 / \mathrm{Nt})$

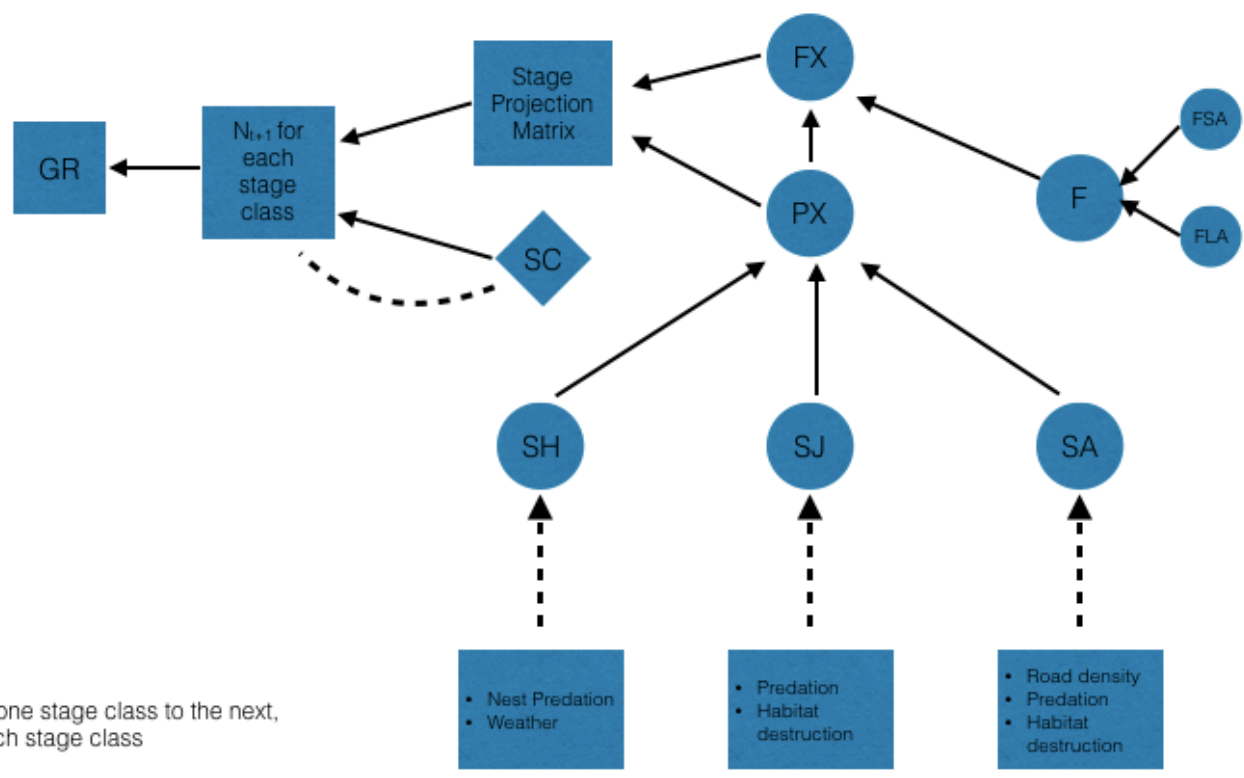

Figure 3.3. Conceptual model of the factors influencing growth rates in Western painted turtles.

Using stage specific survivorship rates published by Mitchell (1988), growth rates for a population of Chrysemsy picta found in a highly anthroponized urban lake were estimated using population stage matrices. The objectives of this study were: (1) Obtain a population growth rate for an urban population of turtles (2) to understand how small changes in stage specific survival rates would impact population growth rate in an urban population of painted turtles; (3) to make conservation and management recommendations. Changes in population survival rates of adults were adjusted to represent management plans dealing with road mortalities. Adjusting fecundity rates were used to understand how management recommendations with increasing nesting availability and basking area would impact growth rates. This is a theoretical model using values found in literature rather than values for the FCH population of western painted turtles, which were unable to be obtained with data collected.

A stage class projection model is a more accurate way to evaluate the population because as a turtle grows, exact age becomes harder to determine (Lindeman and Rabe 1990). Furthermore, turtles have been found to grow more than one annuli in a year (Wilson et al. 2003; Bury et al. 2010). There are four life stages for Western painted turtles: hatchling, juvenile, small adult and large adult (Figure 3.4). Individuals are considered hatchlings as soon as they emerge from the eggs in the nest. Survival rates of hatchlings are typically very low. Predation of the nest and the ability to survive winter temperatures (Nagle et al. 2000) are two factors that decrease survival rates. Once the hatchlings emerge from the nest and enter the water they are considered juveniles. They remain in the juvenile stage until maturity ( 4 years for male and 7 years for females). Only the females in the population are used in the model. Once the female reaches maturity she is considered a small adult. The difference between the small and large adult is the number of nests laid per year. Larger female turtles are known to be able to nest more than one time during a 
season. Because of this the fecundities are different for large and small adults, represented by a fourth age class. An adult will continue to reproduce until death, with at least one nest per year.

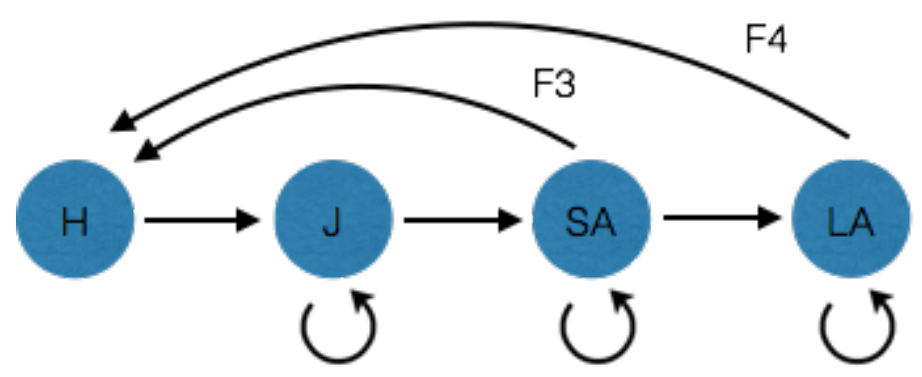

Figure 3.4. Life cycle graph of life stages of turtles. First stage $(H)$ is hatchlings which is from egg to emerging from the nest. Second stage (J) is juvenile, which is from hatchling emergence up to age of maturity (6-7 years). The final two stages small adult (SA) and large adult (LA) is from maturity to death (30+). The last two are broken up because although survivorship is the same in each, fecundity differs. Small adults only produce one nest per season (F3) while the largest females will produce two (F4).

Matrix model and Parameters

A Leftivotch stage classified projection matrix model (A) was used to estimate growth rates of the population. Calculation methods (Table 3.6) for each of the probabilities (P) and fecundities (F) in the matrix followed calculations set up by Enneson and Litzgus (2008) and using survival values from Mitchell (1988). The model was run 50 times, staring with 100 individuals in each age class.

$$
A=\left(\begin{array}{ccc}
0 & 0 & F_{3} \\
P_{21} & P_{22} & 0 \\
0 & P_{32} & P_{33}
\end{array}\right)
$$

The values were used to calculate the different parameters of the matrix using the equations. A matrix model was built using software Matlab. The elasticity matrix parameters (Matrix 2) were calculated from the original matrix (Matrix 1; Equation E). Elasticity is calculated from the sensitivity analysis (Equation S), and indicates how small changes in the vital rates will affect the growth rate of the population (Caswell 2001). The elasticity matrix is a standardization of the sensitivity analysis so it can be compared across matrix manipulations.

$$
E_{i j}=\frac{a_{i j}}{\lambda} \cdot \frac{v_{i} \cdot w_{j}}{\langle w, v\rangle} \quad S_{i j}=\frac{v_{i} \cdot w_{j}}{\langle w, v\rangle}
$$




\begin{tabular}{|c|c|c|c|}
\hline Parameter & Code & Equation/Source & Value \\
\hline \multicolumn{4}{|l|}{ Stage Survival Success } \\
\hline Hatchling & $\sigma \mathrm{H}$ or $\mathrm{P} 12$ & Mitchell (1988) & 0.193 \\
\hline Juvenile (J) & $\sigma J$ & Mitchell (1988) & 0.457 \\
\hline Small Adult (SA) & $\sigma S A$ & Mitchell (1988) & 0.944 \\
\hline Large Adult (LA) & бLA P44 & Mitchell (1988) & 0.963 \\
\hline Clutch Size & CS & Mitchell (1988) & 8 \\
\hline Clutch frequency & CF & Enneson Litgus(2008) & 0.64 \\
\hline Fecundity SA & F3 & $((\mathrm{CS} * \mathrm{CF}) / 2) * \sigma S A$ & \\
\hline Fecundity LA & $\mathrm{F} 4$ & $\mathrm{~F} 3 * 2$ & \\
\hline \multicolumn{4}{|l|}{ Transition Probability } \\
\hline $\mathrm{J}$ to $\mathrm{SA}$ & $\gamma J A$ & $y i=\frac{\left.\left(\frac{\sigma i}{\lambda}\right)^{\mathrm{Ti}}-\frac{\sigma i}{\lambda}\right)^{\mathrm{Ti}-1}}{.}$ & \\
\hline SA to LA & үSLA & $\left.r l-\frac{\sigma i}{\lambda}\right)^{\mathrm{Ti}}-1$ & \\
\hline Prob. Staying as a J & P22 & $\sigma J^{*}(1-\gamma J A)$ & \\
\hline Transition from J to SA & P32 & $\gamma J A * \sigma J$ & \\
\hline Prob. Staying as SA & P33 & $\sigma S A^{*}(1-\nu S L A)$ & \\
\hline Transition from SA to LA & P43 & $\gamma S L A * \sigma S A$ & \\
\hline
\end{tabular}

To meet the objectives of this study, a number of simulations were run that included differences in road mortality and nesting success. Vital rates of stage specific survival will impact the probabilities found in the matrix and eventually the asystemic growth rate $(\lambda)$. Survivorship of each stage class was adjusted by $10 \%$ while holding the others constant as part of a model to understand elasticity and what the thresholds were for each stage class. Using information gained from this analysis guided which other simulations should be run with the model to understand the different management and conservation effects.

The road mortality simulation of the model was run by reducing both small and large adult survivorship by 30 percent to assess the impacts of decreased survivorship of adults to overall population growth. The model was then adjusted to determine the lowest percent of survival needed in order to maintain a positive growth rate $(\lambda>1)$. The nesting success model was built off the original model, but the clutch size and clutch frequency was adjusted to change the overall fecundity values that were used to build the matrix.

Results

Using the survivorship demographic data from Mitchell (1988), the original matrix was calculated (Matrix 1). The population growth rate for the original matrix was 1.096. A 
growth rate greater than one indicates population growth, so this population is slightly growing.

Matrix 1. Original survivorship matrix, projection model (A)

\begin{tabular}{|cccc|}
\hline 0 & 0 & 2.41664 & 4.83328 \\
0.193 & 0.315407458 & 0 & 0 \\
0 & 0.141592542 & 0.489802243 & 0 \\
0 & 0 & 0.454197757 & 0.963 \\
\hline
\end{tabular}

Elasticity was highest for the large adult survivorship element of the matrix (0.55). This value was much higher than any other of the parameters, even matrixes containing small adult survivorship.

Matrix 2. Elasticity matrix

\begin{tabular}{|rrrr|}
\hline 0 & 0 & 0.011166391 & 0.076429042 \\
0.087595432 & 0.035406746 & 0 & 0 \\
0 & 0.087595432 & 0.070809264 & 0 \\
0 & 0 & 0.076429042 & 0.554568651 \\
\hline
\end{tabular}

The left and right eignvectors were calculated from the matrix and were used to calculate the elasticity and sensitivity matrix. The left eignvector $(v)$ is also known as the reproductive values of each stage, indicating the worth of each of the stages to their contributions to future generations. The small and large adults are the largest with 31.28 percent and 36.42 percent more of a contribution then the hatchlings. This is consistent with the findings for the elasticity. The right eignvector $(w)$ indicates the stable stage distribution. For a stable population, most of the individuals should be hatchlings (66\%). Small and large adults only comprise three percent and 16 percent of the population respectively.

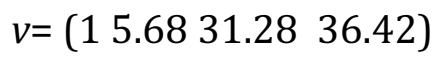

$$
\mathrm{w}=\quad \begin{array}{r}
0.665362746 \\
0.164569137 \\
0.038457108 \\
0.13161101
\end{array}
$$

Survivorship resulting in reduced growth rates was found to be most significant in small and large adults (Figure 3.5). Only a 20\% reduction in survivorship of large adults can occur before the population is declining. Reduction in hatchling survival rates (with others constant) were found not to have a negative growth rate $(\lambda<1)$. If fact the hatchling survival rate could be decreased to as low as four percent before the population growth rate declined $(\lambda<1)$. 


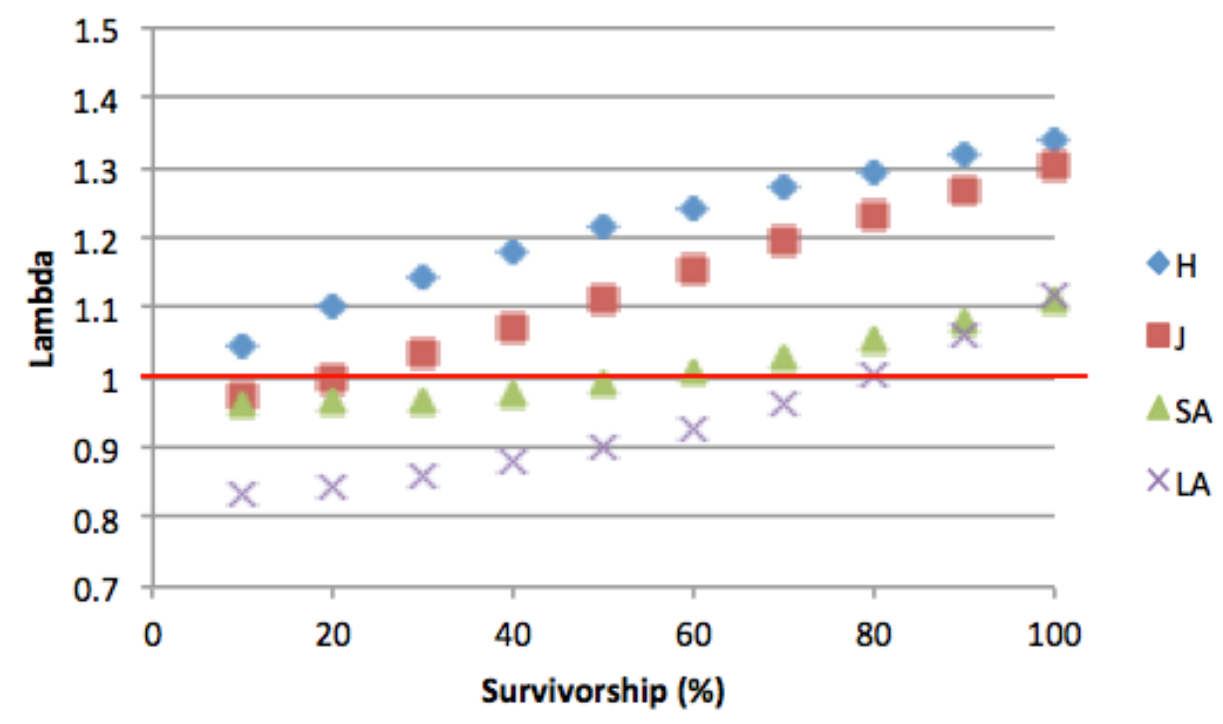

Figure 3.5. Simulations adjusting the survival rate (y axis) of each stage while keeping the rest constant. This showed at which point each stage class started to have a positive growth rate $(\lambda>1$; red line). Values for each age class resulting in $\lambda=1$ are as followed: hatchling 0.04 (4\%), juvenile 0.3 (30\%), small adult $0.6(60 \%)$, and large adult $0.8(80 \%)$.

Road mortality simulated by reduction in survival rates of both small and large adults simultaneously was found to decrease growth rate starting at $12 \%$ mortality. Small adults had the lowest population size of all of the age classes for all simulations (right eigenvalue, $w$, and Figure 3.6). Starting at a mortality rate of $30 \%$ adults rate were tested $(20,15,12 \%)$ until a positive growth rate was achieved at $10 \%$ mortality. Elasticity was analysed with each simulation as was found to be consistent with the original matrix with large adult survivorship to be most valuable.

Adjustment of clutch size and clutch frequency to simulate management actions of nest protection and increasing nesting and basking habitats for adult turtles resulted in small changes in overall population growth rate. Increasing the clutch frequency from 0.64 to 0.94 raised the growth rate from 1.096 to 1.14 . Elasticity values are consistent with the original matrix. 


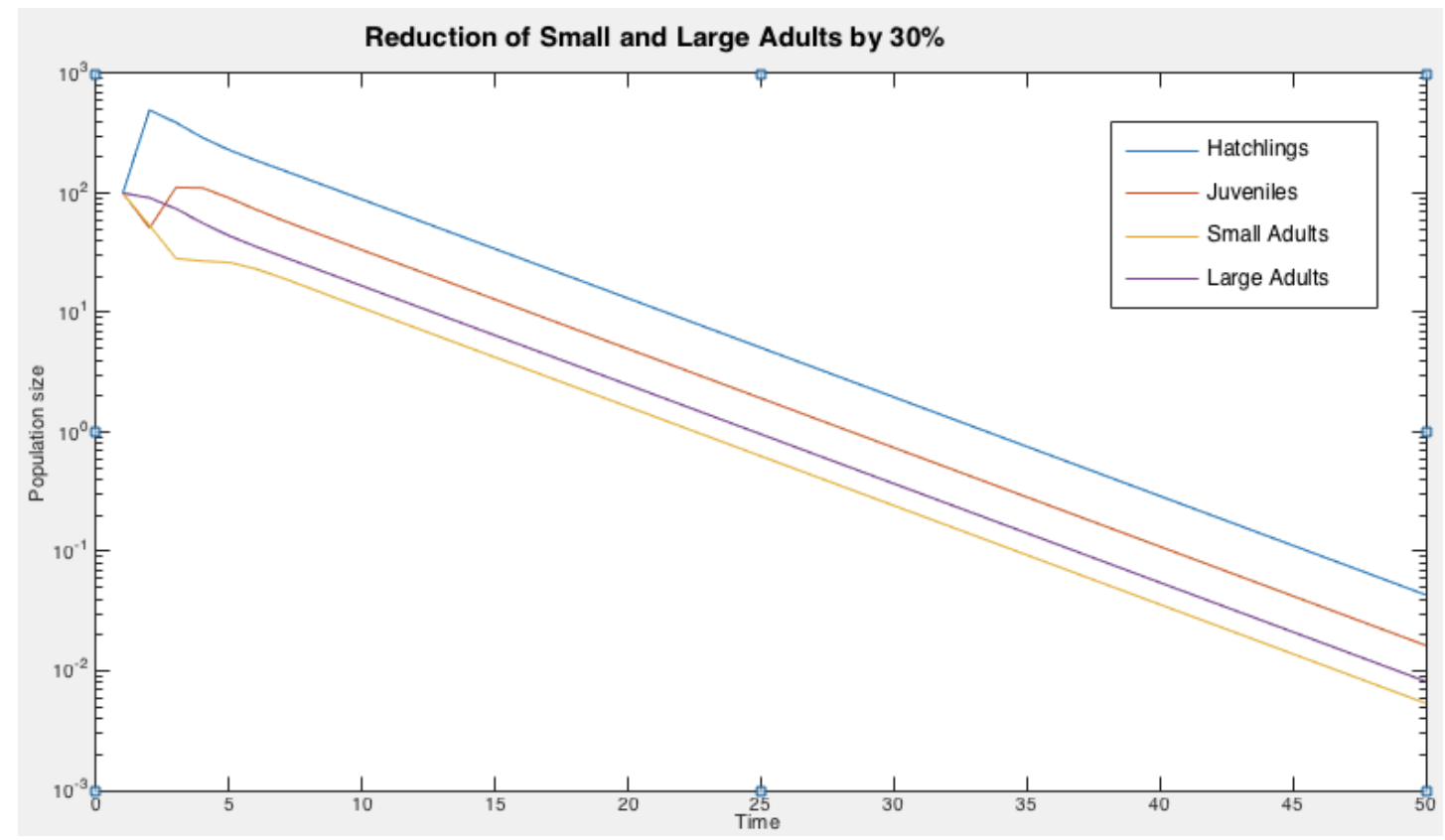

Figure 3.6. A declining growth rate of 0.82 was found when both the small and large adult survivorship was reduced to 30 percent, reflecting thirty percent of the population mortality was due to road mortality. Maintaining a stable population was not achieved until mortality was reduced to $10 \%$ in both stage classes.

While confident in the results from this model as good predictors of management actions needed to take place, there were a few issues and concerns that should be addressed with any reiterations of the model. The main issue stems from the equation calculating the transition probabilities ( $\gamma$; Table 3.1) in the original matrix (A). Enneson and Litzgus (2008) claimed that Ti was the duration of the stage however when calculating the transition probability, the correct growth rate was not calculated when using the duration time of the stage (should have been equal to $\lambda$ in the equation). To make the population growth rate $(\lambda)$ and transition probability equal, the duration time (Ti) was adjusted until the calculated growth rate was achieved and the matrix parameters were correct.

\section{Discussion of Model}

Management of freshwater turtle population usually focuses on protection and enhancement of nesting habitat. Basking habitat is also recognized as important for activities such as temperature regulation, egg incubation, and energetics in turtles. Adult survivorship was found through several different simulations in this study to continually be the most important variable for impacting the population growth rate, thus indicating conservation efforts need to focus on maintaining high adult survival rates. While there are a few sources of adult mortality in a population including predation, removal for pet trade, and dogs, road mortality is a common source of death in many urban areas. Reducing road mortality would be one of the most important management options for maintaining stable populations of turtles in urban areas. 
Female mortality has been closely linked with the abundance of roads near by a site (Steen et al. 2006). Marchand and Litvaitis (2004b) found that females migrating to uplands tend to cross roads leading to higher mortality rates. Furthermore, roads act as ecological traps (Aresco 2005) have many of the same habitat characteristics that turtles are looking for in a nest site: open, low vegetation and gravelly soil. Results from this model indicate the importance of adult survivorship. Only ten percent of small and large adults could be killed through road mortality in the model before the population would begin to decline. Steen et al. (2006) found that roads had a disproportionality higher impact on some age classes of turtles. When the adult age class is reduced that can caused low reproductive success and output (Aresco 2005), low recruitment (Marchand and Litvaits 2004b) and skewed sex ratios (Marchand and Livaits 2004b; Steen et al. 2006).

The finding of adult survival rates being important as well as the left eigenvalue indicating over thirty percent higher individual contribution by the small and large adults, sixty percent collectively, indicates that basking habitat might be just as important as nesting habitat to site development. Having appropriate basking habitat will allow females to increase their reproductive success by incubating their eggs longer and having a higher chance of laying multiple nests in a year. Females will also be able to grow larger by having adequate feeding and basking habitat, thus increasing their reproductive value by moving from a small adult to a large adult.

It was found that the small and large adults were the smallest proportion of the population (right eigenvalue, $w$ ) yet their survival is most important for population growth. Once the turtles reach a sustainable size they are able to live a very long time. Adult turtles often live for $30+$ years, in fact in this population several adults over 20 years old were found. The model predicts that in order to have a sustainable population 60 percent of small adults need to survive and $80 \%$ of large adults need to survive. Thus management should focus on maintaining these small proportion of the population. Options such as fences put up on the edge of roads, providing nesting habitat in areas that reduce changes of mortality through road crossing,

The hatchlings were the highest proportion, with a low survival rate. There were fewer individuals that make it to the adult stages, but if they did they have the greatest chance of survival and are the most important contributors to the population growth. Turtles are investing in a bet hedging life history strategy, with high mortality in the early life stages. This life history strategy along with results from the model indicate that future management for freshwater turtle populations should be adjusted to incorporate greater emphasis on the adult life stages and improving the habitat types used during that stage. 


\section{Chapter 4: Management Plan}

\section{Objective}

Recommendations made are based on findings from the habitat assessment, habitat surveys, and population assessments and models. The objective of this section is to highlight findings and recommendations from all the sections and use those to make recommendations for the newly acquired Gantenbein Property on the north end of FCH.

Habitat Recommendations

Site Vegetation

Based on the findings of the habitat studies, terrestrial vegetation on the site should be sparse with areas of bare ground. Planting the newly acquired area to have low plant density and minimize RCG colonization is essential. Reed Canary grass forms dense mats which impedes the movement of turtles throughout the site. This can include nesting females trying to move through the thick grass and find bare ground for nesting, as well as hatchlings trying to make it from the nest to the water. Often times the thick fibrous root of RCG will trap turtle hatchlings in the nests, as they are not able to push their way through it to the surface.

Rush species were found to be an important emergent vegetation at FCH. Also the presence of milfoil is important for predator avoidance and feeding in the aquatic environment. The functions of these species provide are essential components in restoration planting plans in known turtle habitat areas. Plants used by turtles in Oregon include: American wild-celery (Vallisneria americana), arrowweed (Pluchea spp), common duckweed (Lemna minor), pondweed (Potamogeton spp), water smartweed (Persicaria hydropiperoides), bulrush or three-square (Scirpu spp), bur reed (Sparganium spp), common reed (Phragmites spp), cattail (Typha spp), lilies (Nuphar spp), milfoil (Myriophyllum spp), rushes (Juncus spp), sedges and spikerushes (Carex and Eleocharis spp), wapato (Sagittaria latifolia) and western skunk cabbage (Lysichiton americanus) (Leatham, 1994; Hayes et al., 1999; Clark, 2001; ODFW 2015). It is important to plant short herbaceous species in areas where nesting habitat is located. It is also important to avoid quick growing plants with extensive or rhizomatous root systems (ODFW 2015). For a complete list of plants based on habitat type see Guidance for Conserving Oregon's Native Turtles including Best Management Practices (ODFW 2015).

\section{Vegetation Maintenance:}

- Light clearing of the nesting areas of vegetation twice a year: once in fall and once in in early spring. Avoid use of chemical and mowing. Maintenance should be done keeping the seasonal activities of turtles in mind in order to avoid harm to turtles (avoid activities from mid-May to mid-July).

- Every 2-3 years, a more labor intensive clearing of the vegetation should take place, includes scraping, raking, spraying with herbicides, hand-pulling, and mowing. 
Remove any trees, shrubs or RCG that might be encroaching on the area around the bare patch.

- Reduce plant density in the southern end of the site (special focus on RCG).

Basking Habitat:

Restoration efforts should be focused on creating basking habitat away from the edges of the channels and open water areas. If possible, the creation of a complex system with downed logs, braided channels (with large deep open areas) and small natural mounds throughout the site would provide the best habitat. Sunny areas along the edges of water bodies are import to ensure basking areas are not too shady, as well as creating enough nesting habitat near the water's edge.

At FCH, the north wetland currently has several artificial basking structures as well as floating logs and natural mud islands that the turtles are using for basking. This current habitat must be maintained with any future site development. It is recommended that the hydrology be further studied to ensure the current habitat isn't altered in a way that would be detrimental. Artificial basking structures should be monitored and repaired as needed each year. Additionally the GIS database should be updated accordingly. Maintenance of these structures should be done on an annual basis as they are known to deteriorate over time. Maintenance should include checking to make sure structures are still present, preform minor repairs, replacing structures with new ones if needed.

\section{Basking habitat recommendations:}

- Annual check-ups and maintenance on the artificial basking structures.

- Maintain the presence of logs in the wetland and allow for additional floating logs to be added.

- Conduct basking surveys with equal effort placed on the southern wetland. Providing more survey effort in the southern wetland will help us understand if the turtles truly are not using the southern end of the site, or to what degree they are using that habitat.

Nesting Habitat:

The railroad bed and the southeast edge of the butte provide excellent nesting habitat. These sites should be protected and maintained. The current method of signage not to enter as well as the large hedgerow along the east side of the area, seem to be working well. Community outreach with the neighborhood should continue to help find other nesting sites and to preserve sites currently found on private property.

The creation of nesting sites is very valuable. It is important to keep urban pressures in mind when restoring an area to create nesting habitat. Nesting habitat should be placed in area with little disturbance from dogs, humans, mowing, and spraying. Additionally, the area should have low, sparse vegetation with little-to-no overhead trees, and the area 
should rarely flood. Evidence of various sized nesting pads working is found throughout literature. However, creating fewer, larger patches might be easier to maintain then several small, one meter square patches. Ammending existing soil to create or enhance nesting area typically works well (Table 4.1). However, soils should also be tested to see if they could be amended through tilling in the soil types needed. Furthermore, fine gravels or clay soils can be added to the top layer of existing soils to suppress unwanted vegetation growth.

Considerations for Nesting Area Placement (ODFW 2015):

- Located on slopes less than 15 percent

- Needs sufficient sun, with a south or southwest facing aspect.

- Variable soil is good, with high clay content, sandy loam, and gravelly cobble (Table 4.1)

- Nests built within $100 \mathrm{~m}$ (325ft) of aquatic habitat. The BMP recommends $50 \mathrm{~m}$, however Baldwin et al. (2004) found greater predation on nests found within 50m of the wetland.

- The ground needs to be disturbed through scarification methods (scraping with equipment or hand tools to create bare ground.

Nesting recommendations:

- Maintain the existing nesting habitat (SE corner of butte and railroad bed).

- Create new habitat in areas with minimal disturbance.

- Continue community outreach and citizen science projects with neighbors.

- New habitats should be close to the wetland (without inundation) and use the proper soil mixture.

- Measures should be taken to limit predator's access to the nesting area, whenever possible.

Table 4.1. TURTLE BMP Soil Mixture - Taken from ODFW (2015).

\begin{tabular}{|c|c|}
\hline Soil/Substrate Type* & Percent of Total Mix \\
\hline Fine Clay & 25 or less \\
\hline Loam & 25 \\
\hline Sand & $25-50$ \\
\hline Small Aggregate & 25 or less \\
\hline \multicolumn{2}{|c|}{$\begin{array}{l}\text { * Use of native (on-site) soils is preferable to prevent introduction of different weeds and soi } \\
\text { microbes. Ideal aggregate (gravel) size is } 1 / 4 \text { in }(0.6 \mathrm{~cm}) \text { minus (rounded if available), but } \\
\text { expert recommendations range from } 3 / 4 \text { in }(2 \mathrm{~cm}) \text { to } 1 / 8 \text { in }(0.3 \mathrm{~cm}) \text {. The purpose of the } \\
\text { aggregate is to aid in weed suppression. }\end{array}$} \\
\hline
\end{tabular}


Recommendations from Population Plan:

Turtle populations are inherently hard to study. The detection probability is very low, leading to population estimates with a great deal of uncertainty. The issue became very obvious when attempting to study the population at Fairview Creek Headwaters using past data collected. While there were some turtles that were seen over many years $(n=144$; $53.5 \%)$, there were still a number of them that were detected only in one year $(n=125$; $46.5 \%$ ). It is recommended that research questions and study design be well thought out before conducting anymore population surveys. Important aspects to consider in survey design include: site selection, effort, detection probability (turtle populations tend to have a low detection probability), seasonality, and capture method.

The population growth model showed that survivorship in adults is important to maintain. Reducing road mortality is one way to maintain high survivorship in adults. It is recommended that exclusion fences be put up around Division Street. The creation of a wildlife crossing (underpass or overpass) could also be beneficial to turtles, but also very costly. The population is currently isolated, there are no nearby populations of western painted turtles. However, Johnson Creek, located across from Powell Boulevard could act as a wildlife corridor for the turtles. The connection of Johnson Creek and Fairview Creek headwaters, will need to be done in a way that reduces the chance of road crossings by turtles as well as make adequate nesting habitat on the south end of Powell next to Johnson Creek so turtles don't attempt to make nests on the south facing slope of Powell Boulevard.

\section{Recommendations for Future Surveys:}

- Baited hoop net trappings should occur down in the southern end to ensure that there are no turtles present there.

- Study overwintering of turtles to determine the location of overwintering sites.

- Design future studies to assess behaviors, site use, and locations of hatchling and juvenile stages at FCH.

- Explore other methods of trapping that might capture smaller individuals in the population. Ream and Ream (1966) found a combination of trapping methods are needed in order to capture the different sex ratio and size class distributions. Trapping methods to be considered are: hand capture, baited net traps, and a basking trap.

- Before continuing with mark-recapture surveys, have clear research questions in mind. This will maximize survey efforts.

- Road barriers should be put in place along Division Street to reduce road crossings by adults. This should be made from a material that the turtles cannot climb (e.g. metal corrugate). See Plan 2 for full details. 


\section{Status of Current wetland}

The turtles are currently utilizing the northern portion of the wetland for feeding, basking, nesting, and potentially overwintering. It is important that any restoration done to the northern portion of the wetland does not impact this current habitat in any significant way. This population is completely surrounded by urbanization and has very little, if any, immigration and emigration. Thus, altering the current habitat to a state where the turtles could no longer occupy it would greatly impact the population.

The Habitat surveys, together with the literature review, revealed that the large open water and emergent vegetation (mainly milfoil species), along with the proximity of adequate nesting habitat that include more sparely vegetated terrestrial habitat, all benefit the turtles.

Recommendations for Restoration Plans:

- Create and maintaining areas of bare ground throughout the site.

- Extend some accessible bare ground upland habitat on the east end of the southern wetland (On rail road bed).

- Maintain and create large areas of open water for turtles to move through. These should be deep and have minimal edge effect (not a meandering channel with lots of edges).

- Maintain emergent vegetation. The milfoil currently located in the northern ponds is benefiting the turtles.

- Make sure there is at least a $500 \mathrm{ft}(150 \mathrm{~m})$ buffer between turtle habitat and any trails, roads, or other disturbances.

\section{Plan 1}

Plan 1 is a low impact plan. It focuses on the creation of nesting habitat in the upland along the west edge of the current wetland. There are also two areas of south aspect hills: one at the north end of the wetland (which has been slightly removed by demolition of the buildings) and a clearing in the trees on the butte (Figure 4.1; green). The north end of the site (Gantenbein property) is gently sloped to the east. Nesting habitat should be created with slopes less than 15 degrees, which can be found along the west edge of the wetland. This plan focuses on upland restoration and would not have any aquatic restoration, therefore limiting its impact on site hydrology. Newly created nesting patches should be maintained to have little or no tree coverage, with sparse-to-low vegetation.

To enhance the nesting habitat in these areas, use the recommended fill mixture found in the Turtle BMP (Table 4.1). It is recommended to rototill the area and fill with the soil mixture. These patches should be placed within $100 \mathrm{~m}$ of the water's edge (ideally $50 \mathrm{~m}$ from the edge). Once these areas are established, regular maintenance should be done to keep the nesting area free of vegetation. The creation of new nesting sites would also provide a great opportunity to study how the site is used and pose further research questions related to nesting habitat, as well as hatchling and juvenile populations in urban areas. 


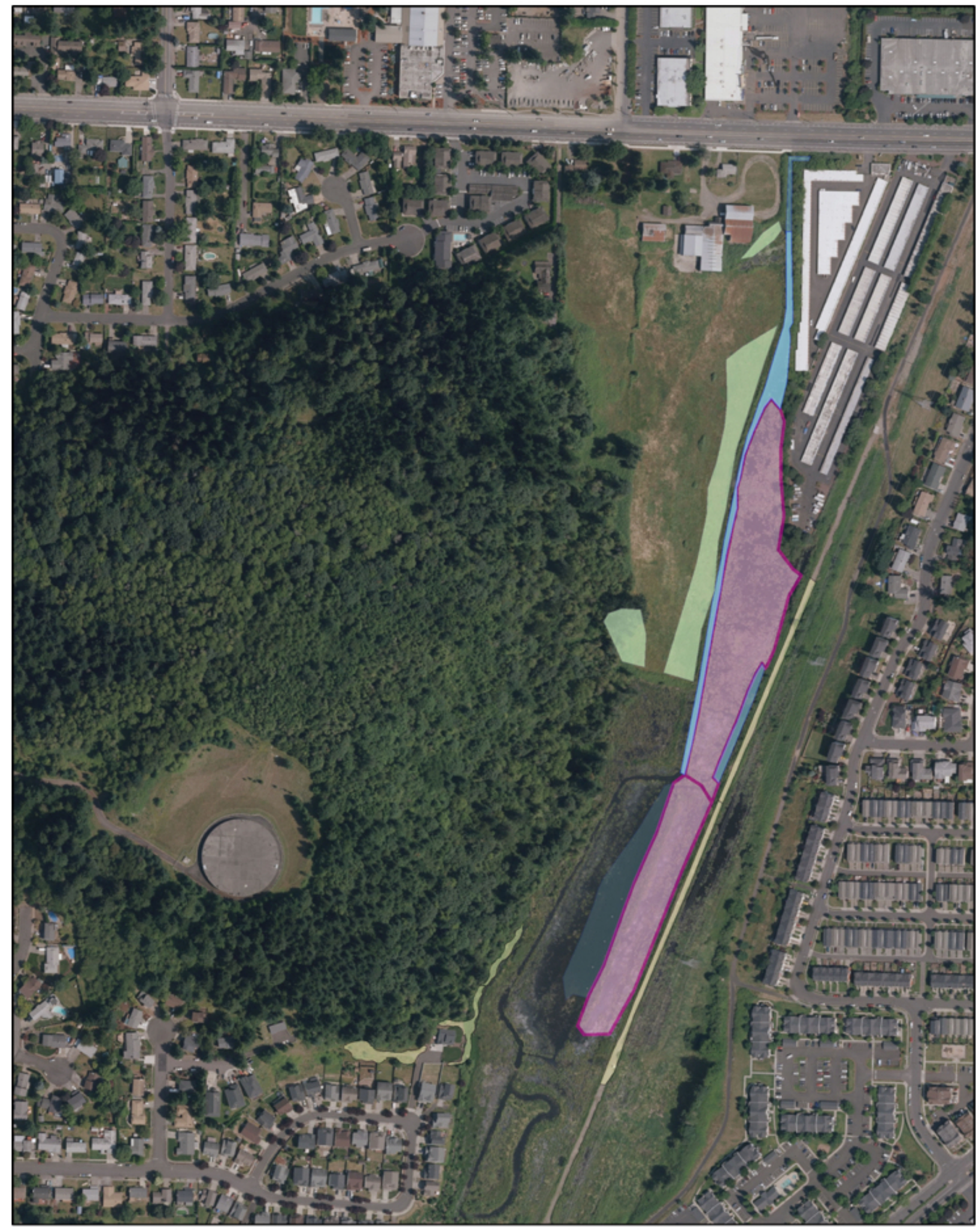


Figure 4.1. Plan 1 - restoration plan. Yellow is known nesting habitat, pink is known aquatic and basking habitat, blue is deeper open water habitat, green is proposed area for nest habitat creation.

Plan 2

Plan 2 focuses on improving aquatic habitat and creating nesting habitat. Aquatic habitat enhancement should include creating a large open wetland with deep areas with thick vegetation that turtles can use for protection from predators and feeding (Figure 4.2red). In this aquatic area, there should be natural basking features such as islands and floating logs. One option is to create nesting habitat on larger islands. Mason Flat wetlands managed by the City of Portland had great success creating nesting islands (Figure 4.3). This larger, open wetland with islands (similar to the north wetland habitat) would create areas of nesting and basking in the middle of the wetland where predation is lower. This will also provide nesting and upland habitat that is away from Division Street an area with high disturbance and potentially increased road mortalities with habitat built closer to it. Additionally, areas in the uplands should be tilled to create even more nesting habitat (Figure 4.2 -orange).

Currently there has been little evidence of turtles being killed on Division Street. When creating additional nesting and aquatic habitat closer to the road this threat is increased (Langen et al. 2012). In order to minimize the turtles being attracted to crossing the road, a few measure should be taken place. First, any nesting habitat created should be in the middle of the site, further from the roads. As was shown in the population model, reductions in adult turtle survivorship is detrimental to the population. Nests placed away from the roads or site edges, will help reduce turtles looking to the edge of the site and road for nesting areas and therefore will most likely reduce adult mortalities from predators, cars and human interactions. Nesting areas created on the Gantenbein property should not be placed near the road. Additionally, a shrub barrier could be added between the wetland and Division Street (Figure 4.4).

Another option is to place a barrier (or fence) between Division Street and the wetland. A fence placed along the entire length of the road would remove any problem with road mortality but would increase the barrier effect (Jaeger and Fahrig 2004). In an area that is highly urbanized with much of the landscape as built environment the benefits of a fence need to be taken into account. Currently the site does not have an issue with road mortality of adult turtles. Jaeger and Fahrig (2004) found that with populations such as FCH's population where road mortality is already low and the population appears to be stable, the use of fences should be avoided. This is because the fence will have a greater impact on the barrier impact (creating a more isolated population) than reducing a few more road deaths. Therefore it is recommended to focus on creating nest habitat in the middle of the site and creating a shrub barrier (that turtles could still pass through) around the north end of the property to not act a turtle barrier for immigration and emigration, but rather a barrier for predators and humans wanting to enter the site. A shrub barrier will help minimize disturbances to the turtle population. This is especially important if additional aquatic habitat is created on the Gantenbein property. 


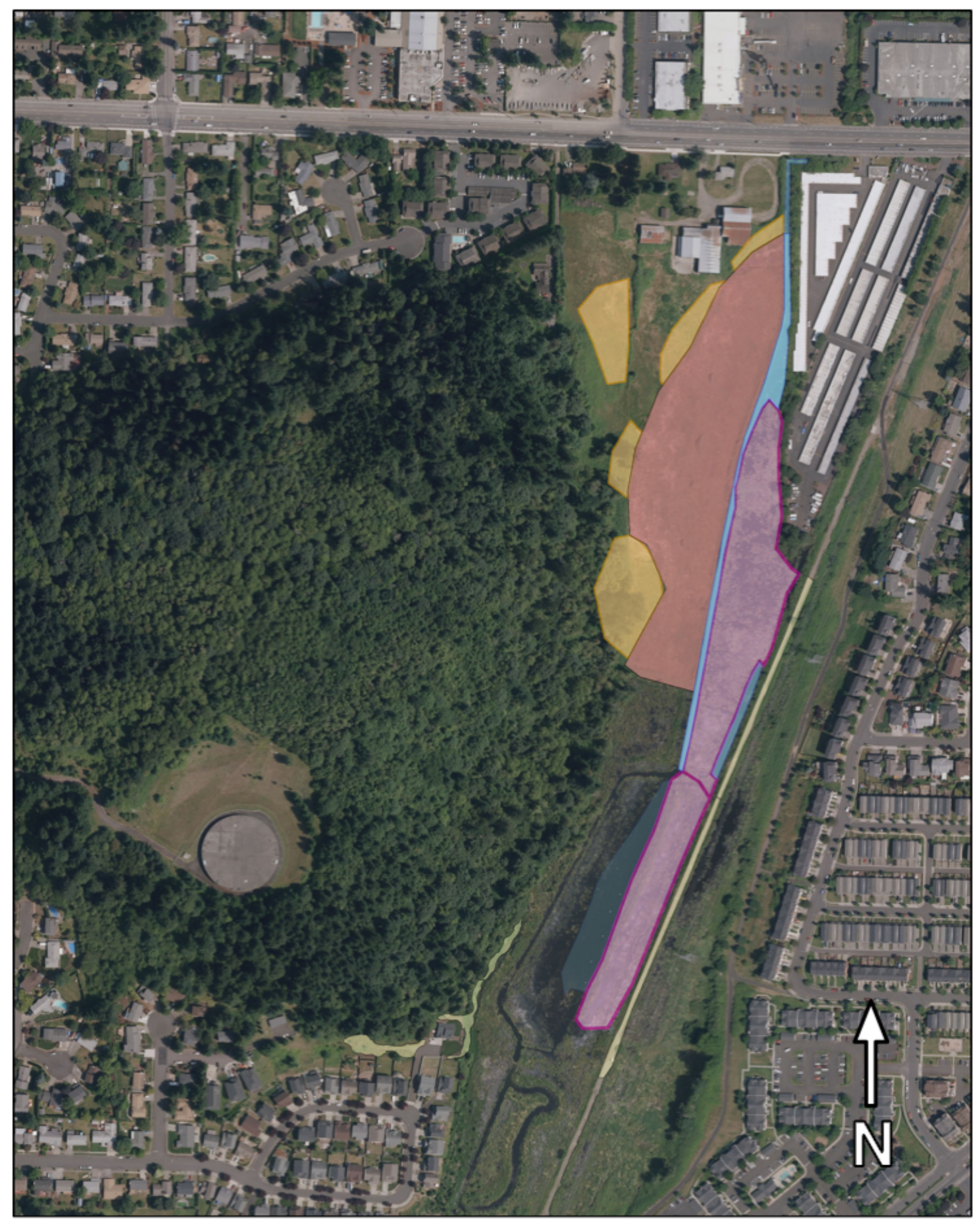

Figure 4.2. Plan 2. Restoration plan. Yellow is known nesting habitat, pink is known aquatic and basking habitat, blue is deeper open water habitat, red is the area identified as an area for improved basking and aquatic habitat, orange are areas for nesting habitat creation. 


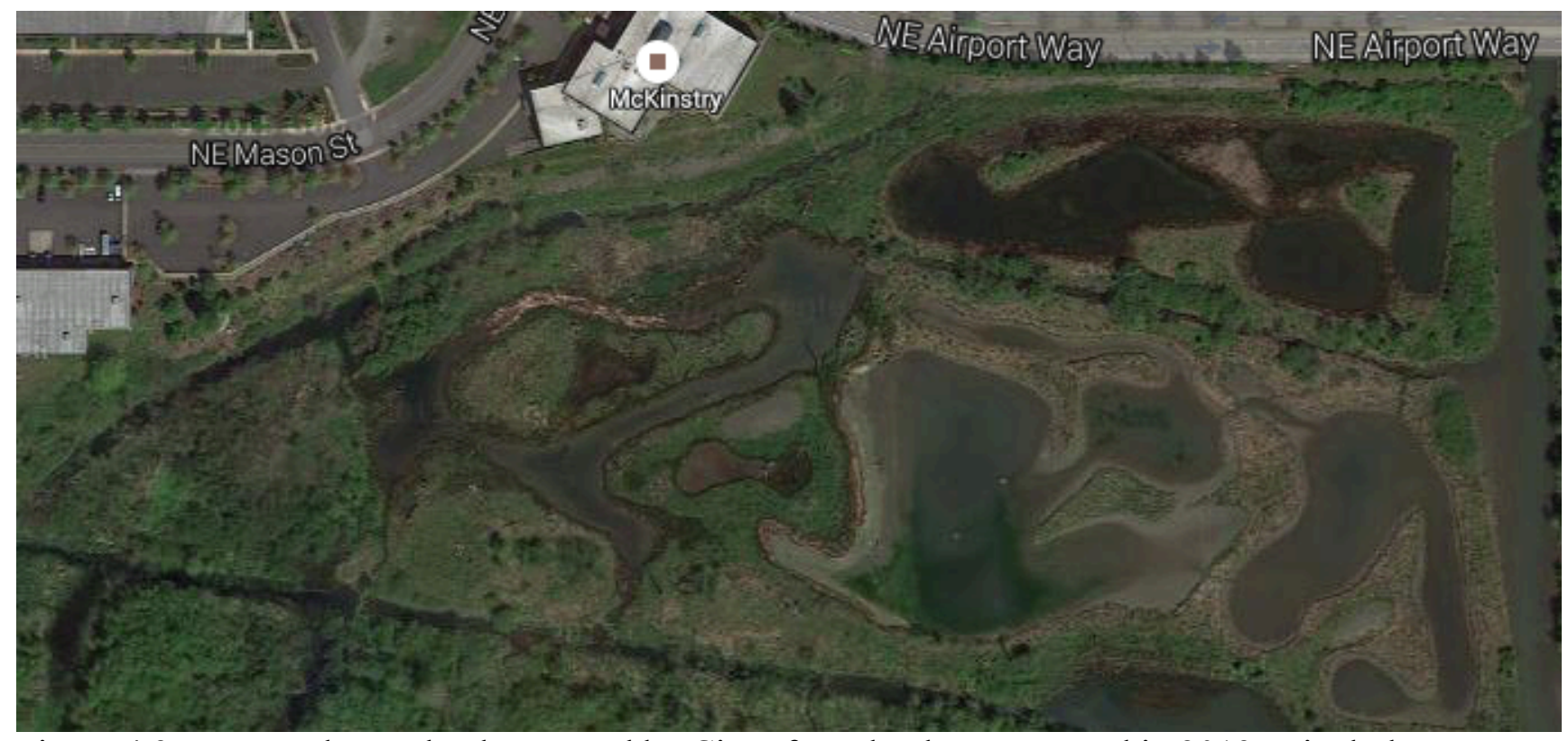

Figure 4.3. Mason Flat wetland managed by City of Portland was restored in 2013 to include nesting and basking islands within the braided wetland. This site could be used as a model for wetland created at FCH as part of plan 2.

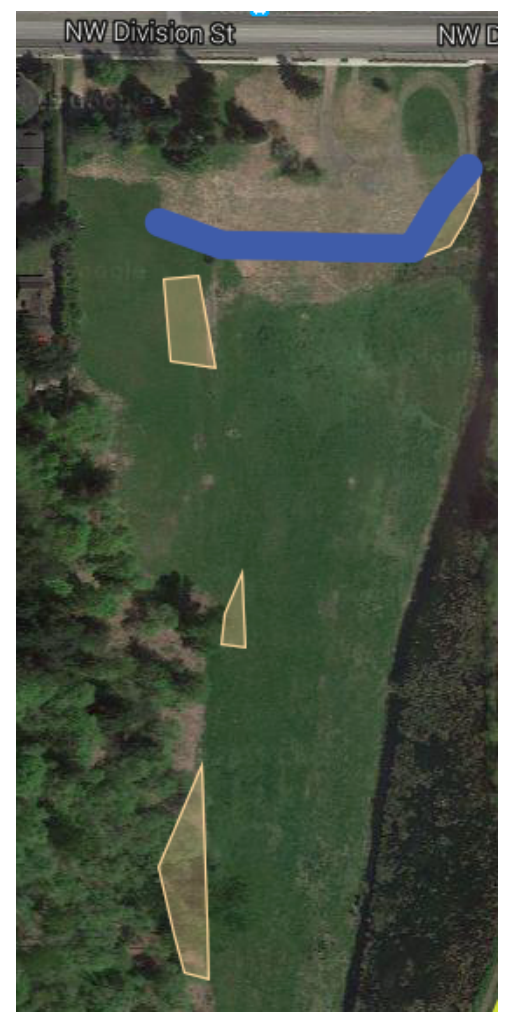

Figure 4.4. Providing a shrub barrier on the north end of the site (blue line) will minimize disturbance from predators, humans and the road. Emphasis placed on creating quality nesting habitat close to the middle of the site, away from highly disturbed edges will help protect adult turtles. 


\section{How to make a turtle platform:}

(1) - ten foot long piece of 3" ABS pipe *cut into 2 three foot lengths and 2 two foot lengths

(1) - PVC cement, 1 pint

(4) - 3" ABS elbows

(3) - 8' x 1" x 6" cedar fencing

*cut one eight foot piece into six 16" lengths for ramps

*cut one more 16 " length from each of the remaining two 8 ' pieces

*cut the remaining two long pieces in half, yielding 4 40" sunning decks
(1) - old bicycle tire

*cut $\sim 6$ " lengths to connect ramps to deck ends

(1)-box of \#8 woodscrews 1 1/2" long

(1)-box of \#8 woodscrews 3/4" long

(2) - 40" lengths of 1"x2" (rough cut wood)

(1) - large roll of galvanized plumber's tape

(1) - small container of gorilla glue

(1)- small roll of mechanic wire

1. On a flat surface, Use PVC cement to connect the ABS pipe and elbows together to form a rectangle.

2. Glue (gorilla glue) each 40 " length of 1 "x2" wood to the top of each long side of the ABS pipe rectangle. Compress the wood and PVC together for 1-2 hours after gluing to assure a strong connection.

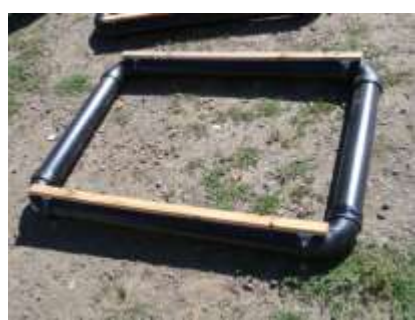

3. Place the four 40 " deck pieces across the top of the rectangle platform, with both ends resting on the 1"x2" wood strips. Evenly space the four deck pieces across the top with 5-6 inches between them. Screw (1 $1 \frac{1}{2}$ ") them at both ends into the two 1 "x2"wood strips. Take care not to puncture the plastic pipe.

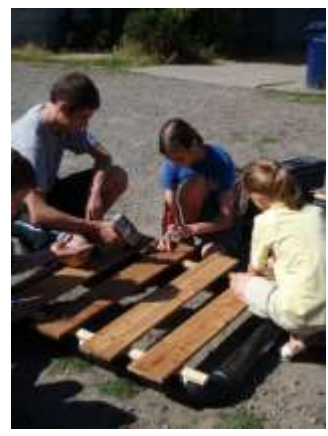


4. Connect the ramps to the end of the deck pieces with the plumber's tape and rubber strips cut from the bicycle tire. First attach plumber's tape with $3 / 4$ " screws onto the 40 " board pieces and attach ramps at approximately a 60 degree angle. Then add rubber strips on top of plumbers tape. The rubber strips will help the ramps last longer as the plumbers tape will likely degrade after a few months.

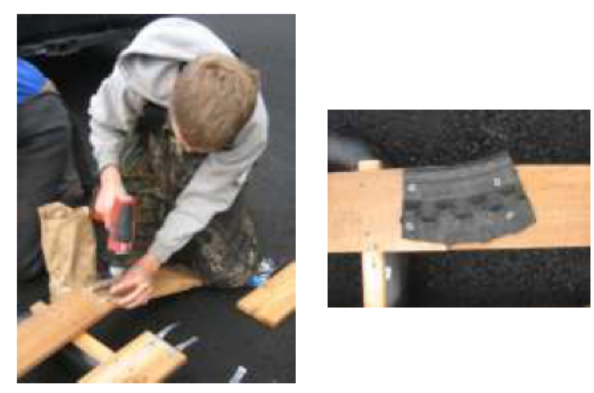

5. Ending results should look something like this! $)$

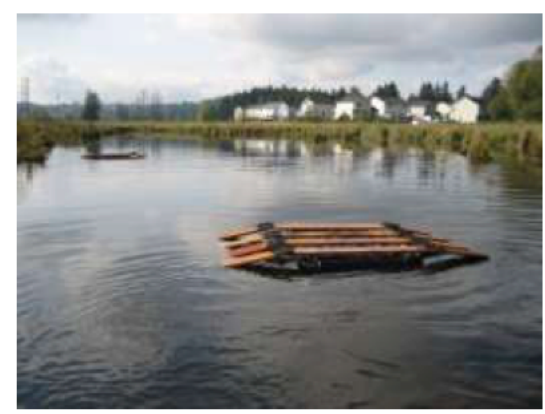




\section{References}

Aresco, M. J. (2005). The effect of sex-specific terrestrial movements and roads on the sex ratio of freshwater turtles. Biological Conservation, 123(1), 37-44.

Auth, D. L. 1975. Behavioral ecology of basking in the yellow-bellied turtle, Chrysemys scripta scripta (Schoepff). Bull. Florida State Mus. Biol. Sci. 20: 1-45.

Baldwin, E. A., Marchand, M. N., \& Litvaitis, J. A. (2004). Terrestrial habitat use by nesting painted turtles in landscapes with different levels of fragmentation. Northeastern Naturalist, 11(1), 41-48.

Barela, K.L., \& Olson D.H. (2014). Mapping the Western Pond Turtle (Actinemys marmorata) and Painted Turtle (Chrysemys picta) in Western North America. Northwest Naturalist, 95 (1):1-12.

Bash, J. S., \& Ryan, C. M. (2002). Stream restoration and enhancement projects: is anyone monitoring?. Environmental management, 29(6), 877-885.

Benjamini, Y., \& Hochberg, Y. (1995). Controlling the false discovery rate: a practical and powerful approach to multiple testing. Journal of the Royal Statistical Society. Series B (Methodological), 289-300.

Benner, P. A., \& Sedell, J. R. (1997). Upper Willamette River landscape: a historic perspective. River quality: dynamics and restoration. CRC Press, Lewis Publishers, New York, 23-47.

Bernert, J. A., Eilers, J. M., Eilers, B. J., Blok, E., Daggett, S. G., \& Bierly, K. F. (1999). Recent wetlands trends (1981/82-1994) in the Willamette Valley, Oregon, USA. Wetlands, 19(3), 545-559.

Bodie JR, Semlitsch RD, Renken RB (2000) Diversity and structure of turtle assemblages: associations with wetland characters across a floodplain landscape. Ecography 23:444-456

Boyer, D. R. (1965). Ecology of the basking habit in turtles. Ecology, 99-118. Bodie, J. R. (2001). Stream and riparian management for freshwater turtles. Journal of Environmental Management, 62(4), 443-455.

Broderick, A. C., \& Godley, B. J. (1996). Population and nesting ecology of the green turtle, Chelonia mydas, and the loggerhead turtle, Caretta caretta, in northern Cyprus. Zoology in the Middle East, 13(1), 27-46.

Brown, D. J., Schultz, A. D., Dixon, J. R., Dickerson, B. E., \& Forstner, M. R. (2012). Decline of red-eared sliders (Trachemys scripta elegans) and Texas spiny softshells (Apalone spinifera emoryi) in the Lower Rio Grande Valley of Texas. Chelonian Conservation and Biology, 11(1), 138-143. 
Burke, V. J., \& Gibbons, J. W. (1995). Terrestrial buffer zones and wetland conservation: a case study of freshwater turtles in a Carolina bay. Conservation Biology, 9(6), 1365-1369.

Bury, R. B. (2001). Western pond turtle: survey protocol and monitoring plan. Final Draft. Interagency Western Pond Turtle Working Group.

Bury, R. B., Germano, D. J., \& Bury, G. W. (2010). Population structure and growth of the turtle Actinemys marmorata from the Klamath-Siskiyou Ecoregion: age, not size, matters. Copeia, 2010(3), 443-451.

Cadi, A., \& Joly, P. (2003). Competition for basking places between the endangered European pond turtle (Emys orbicularis galloitalica) and the introduced red-eared slider (Trachemys scripta elegans). Canadian Journal of Zoology, 81(8), 1392-1398.

Cagle, F.R. 1939. A system of marking turtles for future identification. Copeia 1939:170-173

Cagle, F. R. (1954). Observations on the life cycles of painted turtles (genus Chrysemys). American Midland Naturalist, 225-235.

Carrière, M. A., Rollinson, N., Suley, A. N., \& Brooks, R. J. (2008). Thermoregulation when the growing season is short: sex-biased basking patterns in a northern population of painted turtles (Chrysemys picta). Journal of Herpetology, 42(1), 206- 209.

Caswell, H. (2001). Matrix population models. John Wiley \& Sons, Ltd.

Chao, A. (1987). Estimating the population size for capture-recapture data with unequal catchability. Biometrics, 783-791.

Christiansen, J. L., \& Gallaway, B. J. (1984). Raccoon removal, nesting success, and hatchling emergence in Iowa turtles with special reference to Kinosternon flavescens (Kinosternidae). The Southwestern Naturalist, 343-348.

Clark, S. L. 2001. Ecological Observations of Juvenile Head-Started Western Pond Turtles (Clemmys marmorata marmorata) in Their First Season in the Wild. Unpublished M.S. Thesis: Portland State University. 135 p.

Congdon, J. D., \& Gatten Jr, R. E. (1989). Movements and energetics of nesting Chrysemys picta. Herpetologica, 94-100.

Congdon, J. D., Dunham, A. E., \& van Loben Sels, R. C. (1993). Delayed Sexual Maturity and Demographics of Blanding's Turtles (Emydoidea blandingii): Implications for Conservation and Management of Long-Lived Organisms. Conservation Biology, 7(4), 826-833.

COSEWIC 2006. COSEWIC assessment and status report on the Western Painted Turtle Chrysemys picta bellii (Pacific Coast population, Intermountain-Rocky Mountain population and Prairie/Western Boreal - Canadian Shield population) in Canada. Committee on the Status of Endangered Wildlife in Canada. Ottawa. vii + 40 pp. 
(www.sararegistry.gc.ca/status/status_e.cfm).

Crawford, K. M. (1991). The winter environment of painted turtles, Chrysemys picta: temperature, dissolved oxygen, and potential cues for emergence. Canadian Journal of Zoology, 69(9), 2493-2498.

CRF 2013. Chrysemys picta. The IUCN Red List of Threatened Species. Version 2015.2

Davis, C. J. (1998). Western pond turtle (Clemmys marmorata pallida) winter habitat use and behavior. Unpubl. Master's thesis, San Jose State University, San Jose, California.

De Lathouder, R., Jones, D. N., \& Balcombe, S. R. (2009). Assessing the abundance of freshwater turtles in an Australian urban landscape. Urban ecosystems, 12(2), 215- 231.

DonnerWright DM, Bozek MA, Probst JR, Anderson EM (1999) Responses of turtle assemblages to environmental gradients in the St. Croix River in Minnesota and Wisconsin, U.S.A. Can J Zool 77:989-1000

Dufrêne, M., \& Legendre, P. (1997). Species assemblages and indicator species: the need for a flexible asymmetrical approach. Ecological monographs, 67(3), 345-366.

Dunne, T. and Leopold, L. B. (1978). Water in Environmental Planning. San Francisco, CO: W. H. Freeman.

Ehrenfeld, J. G. (2000). Evaluating wetlands within an urban context. Ecological Engineering, 15(3), 253-265.

Enneson, J. J., \& Litzgus, J. D. (2008). Using long-term data and a stage-classified matrix to assess conservation strategies for an endangered turtle (Clemmys guttata). Biological Conservation, 141(6), 1560-1568.

Ernst, C. H. (1971). Population dynamics and activity cycles of Chrysemys picta in southeastern Pennsylvania. Journal of Herpetology, 151-160.

Ernst, C. H., \& Lovich, J. E. (2009). Turtles of the united states and Canada. JHU Press.

Ewert, M. A., and C. E. Nelson. 1991. Sex determination in turtles: diverse patterns and some possible adaptive values. Copeia 1991:50-69.

Failey, E. L., McCoy, J. C., Price, S. J., \& Dorcas, M. E. (2007). Ecology of turtles inhabiting golf course and farm ponds in the western Piedmont of North Carolina. Journal of North Carolina Academy of Science, 123, 221-232.

Findlay CS, Houlahan J (1997) Anthropogenic correlates of species richness in southeastern Ontario wetlands. Conserv Biol 11:1000-1009

Galat DL, Fredrickson LH, Humberg DD, Bataille KJ, Bodie JR, Dohrenwend J, Gelwicks GT, 
Havel JE, Helmers DL, Hooker JB, Jones JR, Knowlton MF, Kubisiak J, Mazo- urek J, McColpin AC, Renken RB, Semlitsch RD (1998) Flooding to restore connectivity of regulated, largeriver wetlands. Bioscience 48:721-733

Garber, S. D., and J. Burger. 1995. A 20-year study documenting the re- lationship between turtle decline and human recreation. Ecological Applications 5:1151-1162.

Garden, J. G., Mcalpine, C. A., Possingham, H. P., \& Jones, D. N. (2007). Habitat structure is more important than vegetation composition for local-level management of native terrestrial reptile and small mammal species living in urban remnants: A case study from Brisbane, Australia. Austral Ecology, 32(6), 669-685.

Gervais, J., Rosenberg, D., Barnes, S., Puchy, C., Stewart, E. (2009). Conservation Assesment for the Western Painted Turtle in Oregon (Chrysemys picta bellii). USFS. Version 1.1

Gibbons, J. W. (1967). Variation in growth rates in three populations of the painted turtle, Chrysemys picta. Herpetologica, 296-303.

Gibbons J.W. 1968a. Reproductive potential, activity, and cycles in the painted turtle, Chrysemys picta. Ecology 49:399-409

Gibbons, J. W. 1968b. Population structure and survivorship in the painted turtle, Chrysemys picta. Copeia, 260-268.

Gibbons, J. W., Scott, D. E., Ryan, T. J., Buhlmann, K. A., Tuberville, T. D., Metts, B. S., \& Winne, C. T. (2000). The Global Decline of Reptiles, Déjà Vu Amphibians. BioScience, 50(8), 653666.

Gibbs, J. P. (2000). Wetland loss and biodiversity conservation. Conservation biology, 14(1), 314-317.

Gatenbein-Grimm, D. (2014, August 19). Personal interview with Laura O. Foster.

Hammond, K. A., Spotila, J. R., \& Standora, E. A. (1988). Basking behavior of the turtle Pseudemys scripta: effects of digestive state, acclimation temperature, sex, and season. Physiological Zoology, 69-77.

Hartweg, Norman. 1944. Spring emergence of painted turtles hatchlings. Copeia 1:20-22.

Hayes, M. P., S. G. Beilke, S. M. Boczkiewicz, P. B. Hendrix, P. I. Ritson, and C. J. Rombough. 2002. The western painted turtle (Chrysemys picta bellii) at the Rivergate Industrial District: management options and opportunities.

Hayes, D. W., K. R. McAllister, S. A. Richardson, and D. W. Stinson. 1999. Washington State Recovery Plan for the Western Pond Turtle. Washington Department of Fish and Wildlife.

Herbert, C. V., And D. C. Jackson. 1985. Temperature effects on the responses to prolonged 
submergence in the turtle Chrysemys picta bellii. II. Metabolic rate, blood acid-base and ionic changes, and cardiovascular function in aerated and anoxic water. Physiological Zoology 56:670-681.

Holland, D. C. (1994). The western pond turtle: habitat and history. Final Report. USDOE Bonneville Power Administration, Portland, OR (United States). Div. of Fish and Wildlife.

Hulse, D., A. Branscomb, J. Giocochea-Duclos, S. Gregory, L. Ashkenas, P. Minear, S. Payne, D. Richey, H. Dearborn, J. Christy, E. Alverson, and M. Richmond. 1998. Willamette River Basin Planning Atlas, first edition. Pacific Northwest Ecosystem Research Consortium, Institute for a Sustainable Environment, University of Oregon, Eugene, OR, USA

Hynes, H. B. N. 1960. The biology of polluted waters. Liverpool Univ. Press. 202 p. 1962. The significance of macroinvertebrates in the study of mild river pollution. p. 235-240. In C. M. Tarzwell, ed. Biological Problems in Water Pollution, 3rd seminar, 1962. U.S. Public Health Service Publ. No. 999-WP-25. 424 p.

IUCN. 2011. IUCN Red List of Threatened Species (ver. 2011.1). Available at:http://www.iucnredlist.org. (Accessed: 16 June 2011).

Iverson, J. B., \& Smith, G. R. (1993). Reproductive ecology of the painted turtle (Chrysemys picta) in the Nebraska Sandhills and across its range. Copeia, 1-21.

Jackson, P. L. and A. J. Kimerling. 1993. Atlas of the Pacific Northwest. Oregon State University Press, Corvallis, OR, USA

Jackson, D. C., E. M. Rauer, R. A. Feldman, And S. A. Reese. 2004. Avenues of extrapulmonary oxygen uptake in western Painted Turtles (Chrysemys picta bellii) at 10uC. Comparative Biochemistry and Physiology A 139:221-227.

Jaeger, J. A., \& Fahrig, L. (2004). Effects of road fencing on population persistence. Conservation Biology, 18(6), 1651-1657.

Janzen, F. J. (1994). Vegetational cover predicts the sex ratio of hatchling turtles in natural nests. Ecology, 1593-1599.

Johnson CM, Johnson LB, Richards C, Beasley V (2002) Predicting the occurrence of amphibians: an assessment of multiple-scale models. In: Scott JM, Heglund PJ, Morri- son ML, Haufler JB, Raphael MG, Wall WA, Samson FB (eds) Predicting species occurrences: issues of accuracy and scale. Island Press, Washington, DC, USA, pp 157- 170

Jones, D. N., \& Wieneke, J. (2000). The suburban bird community of Townsville revisited: Changes over a 17 year period.

Kendall, W. L., Pollock, K. H., \& Brownie, C. (1995). A likelihood-based approach to capturerecapture estimation of demographic parameters under the robust design. Biometrics, 293308. 
Kentula, M. E., S. E. Gwin, and S. M. Pierson. 2004. Tracking changes in wetlands with urbanization: sixteen years of experience in Portland, Oregon, USA. Wetlands 24:734-743.

Klein, R. D. (1979). Urbanization and stream quality impairment. Water Resources Bulletin, 15(4), 948-963.

Klemens MW. 1993. The amphibians and reptiles of Connecticut and adjacent regions. State Geological and Natural History Survey of Connecticut, Bulletin 112:1-318.

Knight, A. W., \& Gibbons, J. W. (1968). Food of the painted turtle, Chrysemys picta, in a polluted river. American Midland Naturalist, 558-562.

Koonz, W. H. (1998). Western painted turtle hatchlings overwintering in Manitoba nests. Blue Jay, 56, 183-184.

Koper, N., and R.J. Brooks. 1998. Population-size estimators and unequal catchability in Painted Turtles. Canadian Journal of Zoology 76:458-465.

Krawchuk, M. A., \& Brooks, R. J. (1998). Basking behavior as a measure of reproductive cost and energy allocation in the painted turtle, Chrysemys picta. Herpetologica, 112-121.

Kutschera, R. (2010). Habitat assessment and conservation recommendations for the western pond turtle (Actinemys marmorata marmorata) and western painted turtle (Chrysemys picta bellii) within the urban growth boundary of Portland, Oregon. Portland State University.

Lagler,K. F. 1943a. Food habits and economic relations of the turtles of Michigan with special reference to fish management. Amer. Midl. Nat. 29(2) :257-312.

Lagler, K.F. 1943b. Methods of collecting freshwater turtles. Copeia 1943:21-25.

Lambert, M. R., Nielsen, S. N., Wright, A. N., Thomson, R. C., \& Shaffer, H. B. (2013). Habitat Features Determine the Basking Distribution of Introduced Red-Eared Sliders and Native Western Pond Turtles. Chelonian Conservation and Biology, 12(1), 192-199.

Langen, T. A., Gunson, K. E., Scheiner, C. A., \& Boulerice, J. T. (2012). Road mortality in freshwater turtles: identifying causes of spatial patterns to optimize road planning and mitigation. Biodiversity and conservation, 21(12), 3017-3034.

Lavergne, S., \& Molofsky, J. (2004). Reed canary grass (Phalaris arundinacea) as a biological model in the study of plant invasions. Critical Reviews in Plant Sciences, 23(5), 415-429.

Leatham, T.M. 1994. 1993 Study of the Western Pond Turtle Clemmys marmorata at Kirk Park, Fern Ridge Reservoir, Oregon. Report to U.S. Army Corps of Engineers.

Legendre, P., \& Legendre, L. F. (2012). Numerical ecology (Vol. 24). Elsevier. 
Lenhart, C. F., Naber, J. R., \& Nieber, J. L. (2013). Impacts of Hydrologic Change on Sandbar Nesting Availability for Riverine Turtles in Eastern Minnesota, USA. Water, 5(3), 12431261.

Leopold, L. B. (1968). Hydrology for urban land planning: A guidebook on the hydrologic effects of urban land use (p. 18). US Government Printing Office.

Lindeman, P. V. (1996). Comparative life history of painted turtles (Chrysemys picta) in two habitats in the inland Pacific Northwest. Copeia, 114-130.

Lindeman, P. V., \& Rabe, F. W. (1990). Effect of drought on the western painted turtle, Chrysemys picta belli, in a small wetland ecosystem. Journal of Freshwater Ecology, 5(3), 359-364.

Lindeman, P. V. (1990). Closed and open model estimates of abundance and tests of model assumptions for two populations of the turtle, Chrysemys picta. Journal of Herpetology, 24(1), 78-81.

Leslie, A., Penick, D., Spotila, J. R., \& Paladino, F. V. (1996). Leatherback turtle, Dermochelys coriacea, nesting and nest success at Tortuguero, Costa Rica, in 1990-1991. Tortuga baula, Dermochelys coriacea, anidamiento y éxito en el nido en Tortuguero, Costa Rica, en 19901991. Chelonian Conserv Biol, 2, 159-168.

Manning, B., \& Grigg, G. C. (1997). Basking is not of thermoregulatory significance in the "basking" freshwater turtle Emydura signata. Copeia, 579-584.

Marchand, M. N., Litvaitis, J. A., Maier, T. J., \& DeGraaf, R. M. (2002). Use of artificial nests to investigate predation on freshwater turtle nests. Wildlife Society Bulletin, 1092-1098.

Marchand, M. N., \& Litvaitis, J. A. (2004a). Effects of landscape composition, habitat features, and nest distribution on predation rates of simulated turtle nests. Biological Conservation, 117(3), 243-251.

Marchand, M. N., \& Litvaitis, J. A. (2004b). Effects of habitat features and landscape composition on the population structure of a common aquatic turtle in a region undergoing rapid development. Conservation Biology, 18(3), 758-767.

Marzluff, J. M. (2001). Worldwide urbanization and its effects on birds. In Avian ecology and conservation in an urbanizing world (pp. 19-47). Springer US.

McCune, B. and M. J. Mefford. 2011. PC-ORD. Multivariate Analysis of Ecological Data. Version 6. MjM Software, Gleneden Beach, Oregon, U.S.A

McCune, B., Grace, J. B., \& Urban, D. L. (2002). Analysis of ecological communities (Vol. 28). Gleneden Beach, OR: MjM software design.

McKinney ML (2006) Urbanization as a major cause of biotic homogenization. Biol Conserv 
Meseth, E. H., \& Sexton, O. J. (1963). Response of painted turtles, Chrysemys picta, to removal of surface vegetation. Herpetologica, 19(1), 52-56.

Miller, R. C., \& Zedler, J. B. (2003). Responses of native and invasive wetland plants to hydroperiod and water depth. Plant ecology, 167(1), 57-69.

Mitchell, J. C. (1985). Female reproductive cycle and life history attributes in a Virginia population of painted turtles, Chrysemys picta. Journal of Herpetology, 218-226.

Mitchell, J. C. (1988). Population ecology and life histories of the freshwater turtles Chrysemys picta and Sternotherus odoratus in an urban lake. Herpetological Monographs, 40-61.

Moll, E0. 1973. Latitudican and intersubspecific variation in reproduction of the painted turtle, chrysemys picta. Herpetologica 29:307-318.

Montgomery, D. R. (1999). Process domains and the river continuum. Journal of the American Water Resources Association, 35(2), 397-410.

Moon, D. Y., MacKenzie, D. S., \& Owens, D. W. (1997). Simulated hibernation of sea turtles in the laboratory: I. Feeding, breathing frequency, blood $\mathrm{pH}$, and blood gases. The Journal of experimental zoology, 278(6), 372-380.

Moore, M. J., \& Seigel, R. A. (2006). No place to nest or bask: Effects of human disturbance on the nesting and basking habits of yellow-blotched map turtles $(<\mathrm{i}>$ Graptemys flavimaculata</i>). Biological Conservation, 130(3), 386-393.

Moyle, P. B., \& Leidy, R. A. (1992). Loss of biodiversity in aquatic ecosystems: evidence from fish faunas. In Conservation biology (pp. 127-169). Springer US.

Nagle, R. D., Kinney, O. M., Congdon, J. D., \& Beck, C. W. (2000). Winter survivorship of hatchling painted turtles (Chrysemys picta) in Michigan.Canadian Journal of Zoology, 78(2), 226-233.

Nedeau, E. J., Merritt, R. W., \& Kaufman, M. G. (2003). The effect of an industrial effluent on an urban stream benthic community: water quality vs. habitat quality. Environmental pollution, 123(1), 1-13.

Nichols, J.T. 1933. Further notes on painted turtles. Copeia 1:41-42.

Oetter, D. R., W. B. Cohen, M. Berterretche, T. K. Maiersperger, and R. E. Kennedy. 2000. Land cover mapping in an agricultural setting using multi seasonal Thematic Mapper data. Remote Sensing of Environment 76:139-155.

Oregon Department of Fish and Wildlife. 2006. Oregon Conservation Strategy. Oregon 
Department of Fish and Wildlife, Salem, Oregon.

ODFW. 2015. Guidance for Conserving Oregon's Native Turtles including Best Management Practices. Oregon Dept. of Fish and Wildlife. 99 pp.

Pollock, K. H. (1982). A capture-recapture design robust to unequal probability of capture. The Journal of Wildlife Management, 46(3), 752-757.

Proulx, C. L., Fortin, G., \& Blouin-Demers, G. (2014). Blanding's Turtles (Emydoidea blandingii) Avoid Crossing Unpaved and Paved Roads. Journal Of Herpetology, 48(2), 267 271.

R Core Team (2015). R: A language and environment for statistical computing. $\mathrm{R}$ Foundation for Statistical Computing, Vienna, Austria. URL http://www.R-project.org/.

Raney, E. C., \& Lachner, E. A. (1942). Summer Food of Chrysemys picta marginata, in Chautauqua Lake, New York. Copeia, 1942(2), 83-85.

Ream, C., \& Ream, R. (1966). The influence of sampling methods on the estimation of population structure in painted turtles. American Midland Naturalist, 325-338.

Rizkalla, C. E., \& Swihart, R. K. (2006). Community structure and differential responses of aquatic turtles to agriculturally induced habitat fragmentation. Landscape Ecology, 21(8), 1361-1375.

Rollinson, N., Tattersall, G. J., \& Brooks, R. J. (2008). Overwintering habitats of a northern population of Painted Turtles (Chrysemys picta): winter temperature selection and dissolved oxygen concentrations. Journal of Herpetology, 42(2), 312-321.

Rosenberg, D., \& Gervais, J. (2012). Conservation Plan for Native Turtles in the Columbia Slough, Portland, Oregon.

Rowe, J. W. (2003). Activity and movements of midland painted turtles (Chrysemys picta marginata) living in a small marsh system on Beaver Island, Michigan. Journal of Herpetology, 37(2), 342-353.

Rubin, C. S., Warner, R. E., Bouzat, J. L., \& Paige, K. N. (2001). Population genetic structure of Blanding's turtles (Emydoidea blandingii) in an urban landscape. Biological Conservation, 99(3), 323-330.

Russell KR, Guynn DC Jr, Hanlin HG (2002) Importance of small isolated wetlands for herpetofaunal diversity in managed, young growth forests in the Coastal Plain of South Carolina. Forest Ecol Manag 163:43-59

Schnabel, Z. E. (1938). The estimation of total fish population of a lake. The American Mathematical Monthly, 45(6), 348-352. 
Schooler, S. S., McEvoy, P. B., \& Coombs, E. M. (2006). Negative per capita effects of purple loosestrife and reed canary grass on plant diversity of wetland communities. Diversity and Distributions, 12(4), 351-363.

Schwarzkopf,L., and R. J. Brooks. 1985. Appli-cation of operative environmental temperatures to analysis of basking behavior in Chrysemys picta. Herpetologica 41:206212.

Semlitsch, R. D., \& Bodie, J. R. (2003). Biological criteria for buffer zones around wetlands and riparian habitats for amphibians and reptiles. Conservation Biology, 17(5), 1219-1228.

Sexton, Owen J. 1959. A method of estimating the age of painted turtles for use in demographic studies. Ecology 40: 716-718.

Shepard, D. B., Kuhns, A. R., Dreslik, M. J., \& Phillips, C. A. (2008). Roads as barriers to animal movement in fragmented landscapes. Animal conservation, 11(4), 288-296.

Shochat, E., Lerman, S. B., Anderies, J. M., Warren, P. S., Faeth, S. H., \& Nilon, C. H. (2010). Invasion, competition, and biodiversity loss in urban ecosystems. BioScience, 60(3), 199208.

Smith,H.M. 1950. Handbook of amphibians and reptiles of Kansas. Misc. Publ. No 2, University Kansas Museum of Natural History. 1-336

Soil Survey Staff. (2014). Soil Survey Field and Laboratory Methods Manual. Soil Survey Investigations Report No. 51, Version 2.0. R. Burt and Soil Survey Staff (ed.). U.S. Department of Agriculture, Natural Resources Conservation Service.

Spencer, R. J. (2002). Experimentally testing nest site selection: fitness trade-offs and predation risk in turtles. Ecology, 83(8), 2136-2144.

Spinks, P. Q., Pauly, G. B., Crayon, J. J., \& Bradley Shaffer, H. (2003). Survival of the western pond turtle $(<\mathrm{i}>$ Emys marmorata $</ \mathrm{i}>$ ) in an urban California environment. Biological Conservation, 113(2), 257-267.

Steen, D. A., \& Gibbs, J. P. (2004). Effects of roads on the structure of freshwater turtle populations. Conservation Biology, 18(4), 1143-1148.

Steen, D. A., Aresco, M. J., Beilke, S. G., Compton, B. W., Condon, E. P., Kenneth Dodd, C., \& Gibbs, J. P. (2006). Relative vulnerability of female turtles to road mortality. Animal Conservation, 9(3), 269-273.

Taft, O. W., \& Haig, S. M. (2003). Historical wetlands in Oregon's Willamette Valley: implications for restoration of winter waterbird habitat. Wetlands, 23(1), 51-64.

Tait, C. J., Daniels, C. B., \& Hill, R. S. (2005). Changes in species assemblages within the Adelaide Metropolitan Area, Australia, 1836-2002. Ecological Applications, 15(1), 346-359. 
Temple, S. A. (1987). Predation on turtle nests increases near ecological edges. Copeia, 1987(1), 250-252.

Titus, J. H., Christy, J. A., VanderSchaaf, D., Kagan, J. S., \& Alverson, E. R. (1996). Native wetland, riparian, and upland plant communities and their biota in the Willamette Valley, Oregon.

Tinkle, D. W., Congdon, J. D., \& Rosen, P. C. (1981). Nesting frequency and success: implications for the demography of painted turtles. Ecology, 1426-1432.

Trombulak, S. C., \& Frissell, C. A. (2000). Review of ecological effects of roads on terrestrial and aquatic communities. Conservation biology, 14(1), 18-30.

Ultsch, G. R., and D. C. Jackson. 1982. Long-term submergence at 3uC of the turtle Chrysemys picta bellii in normoxic and severely hypoxic water-I. Survival, gas exchange, and acid-base status. Journal of Experimental Biology 96: 11-28.

Umphrey, A., Kletchko, A., \& Desrosiers, D. (2012). Basking Preferences and Interspecies Interactions of the Western Painted Turtle (Chrysemys picta bellii) at Swan Lake, Victoria, BC. Prepared for Camosun College Enviornmental Technology Department.

United Nations, Department of Economic and Social Affairs, Population Division (2014). World Urbanization Prospects: The 2014 Revision, Highlights (ST/ESA/SER.A/352).

Van Dijk, P.P. 2013. Chrysemys picta. The IUCN Red List of Threatened Species. Version 2015.2. <www.iucnredlist.org $>$.

Violin, C. R., Cada, P., Sudduth, E. B., Hassett, B. A., Penrose, D. L., \& Bernhardt, E. S. (2011). Effects of urbanization and urban stream restoration on the physical and biological structure of stream ecosystems. Ecological Applications, 21(6), 1932-1949.

Vitousek, P. M., H. A. Mooney, J. Lubchenco, and J. M.Melillo. (1997). Human domination of Earth's ecosystems. Science 267:880-883.

Wace, N. (1977). Assessment of dispersal of plant species-the car-borne flora in Canberra. In Proceedings of the Ecological Society of Australia (Vol. 10, pp. 167-186).

Wilbur, H. M.. (1975). The Evolutionary and Mathematical Demography of the Turtle Chrysemys picta. Ecology, 56(1), 64-77.

Wilson, D. S., Tracy, C. R., \& Tracy, C. R. (2003). Estimating age of turtles from growth rings: a critical evaluation of the technique. Herpetologica, 59(2), 178-194.

Zweifel, R. G. (1989). Long-term ecological studies on a population of painted turtles, Chrysemys picta, on Long Island, New York. American Museum novitates;; no. 2952. 